\title{
Special Purpose Application Reactors: Systems Integration Decision Support
}

John C. Kennedy

Piyush Sabharwall

Konor Frick

Mike McKellar

Shannon Bragg-Sitton

From Los Alamos National Laboratory:

D.V. Rao

Patrick McClure

January 2019

The INL is a U.S. Department of Energy National Laboratory operated by Battelle Energy Alliance 


\section{DISCLAIMER}

This information was prepared as an account of work sponsored by an agency of the U.S. Government. Neither the U.S. Government nor any

agency thereof, nor any of their employees, makes any warranty, expressed or implied, or assumes any legal liability or responsibility for the accuracy, completeness, or usefulness, of any information, apparatus, product, or process disclosed, or represents that its use would not infringe privately owned rights. References herein to any specific commercial product,

process, or service by trade name, trade mark, manufacturer, or otherwise, does not necessarily constitute or imply its endorsement, recommendation, or favoring by the U.S. Government or any agency thereof. The views and opinions of authors expressed herein do not necessarily state or reflect those of the U.S. Government or any agency thereof. 


\title{
Special Purpose Application Reactors: Systems Integration Decision Support
}

\author{
John C. Kennedy \\ Piyush Sabharwall \\ Konor Frick \\ Mike McKellar \\ Shannon Bragg-Sitton \\ From Los Alamos National Laboratory: \\ D.V. Rao \\ Patrick McClure \\ January 2019
}

Idaho National Laboratory Idaho Falls, Idaho 83415

http://www.inl.gov

Prepared for the

U.S. Department of Energy

Office of Nuclear Energy

Under DOE Idaho Operations Office

Contract DE-AC07-05ID14517 



\title{
Special Purpose Application Reactors: Systems Integration Decision Support
}

\author{
INL/EXT-18-51369 \\ Rev. 1
}

January 2019

Technical Reviewer:
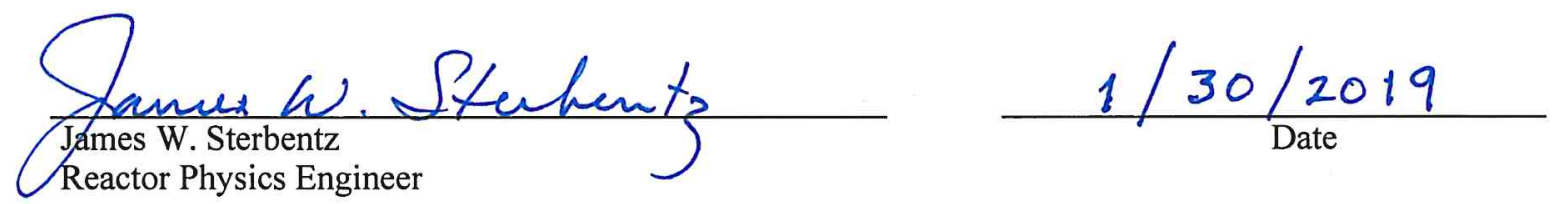

Co-Author:

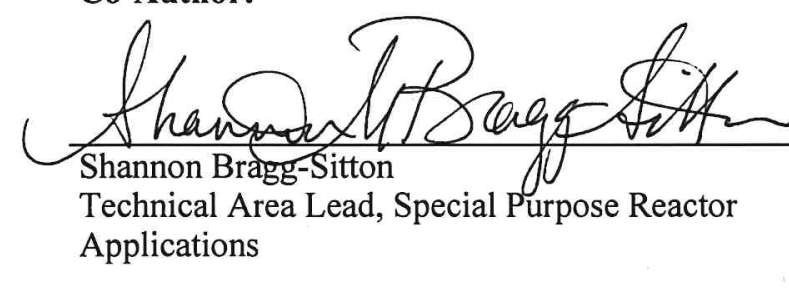

Approved by:
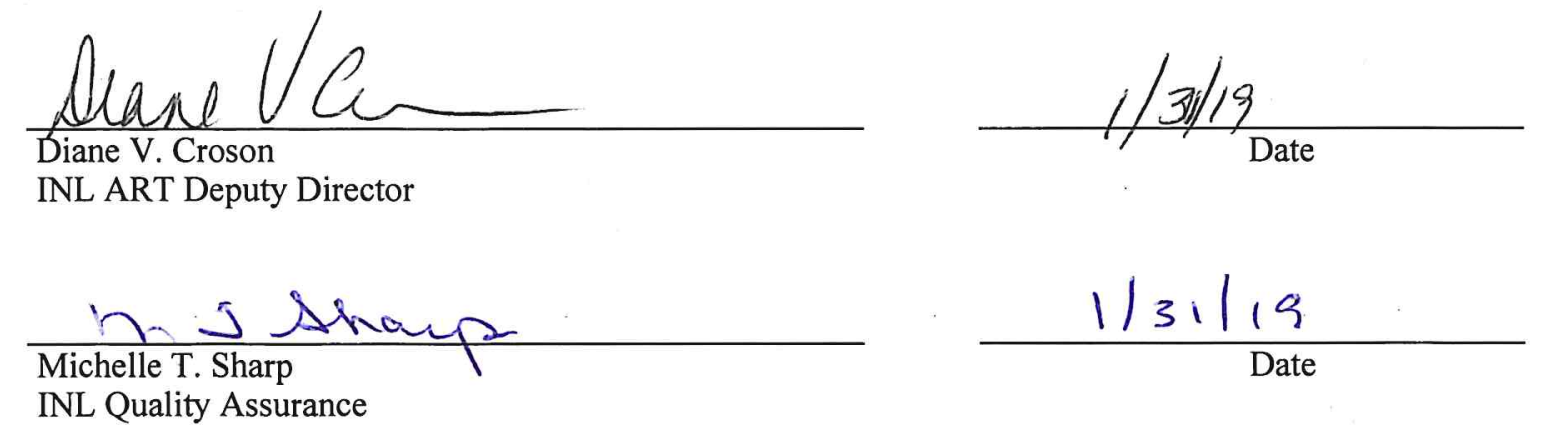


\section{SUMMARY}

Microreactors, also known as very-Small Modular Reactors (vSMRs) or Special Purpose Reactors (SPRs), are being considered for use in unique applications where other methods of megawatt level energy production are uneconomical or unavailable. For the purposes of this report, a microreactor is defined as meeting the following criteria:

- Factory manufacturable

- Easily transportable by truck, plane, train, and/or ship

- Produce no more than 20 megawatt thermal (MWth) energy, in order to qualify as Hazard Category 2 under 10CFR830

- Maintains neutronic simplicity, allowing semi- or fully-autonomous operation

In the United States (U.S.), there are two general types of microreactors under development: high-temperature gas reactors (HTGRs) and heat pipe reactors. These two reactor types may, due to their differences in working fluid temperatures, be more effectively suited to different use cases. Additionally, they will require different interfacing components depending on their intended use.

This report identifies a broad range of use cases for micro-reactors. Additionally, multiple reactor technologies are examined with an emphasis on the reactor sub-systems and interconnections. Using this information, a decision support framework is developed to guide future efforts. 


\section{CONTENTS}

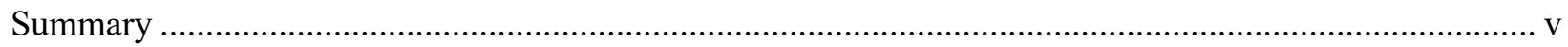

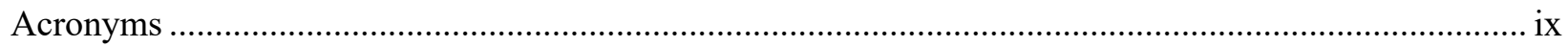

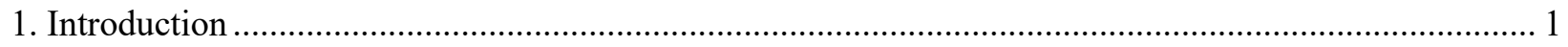

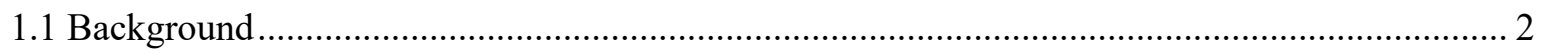

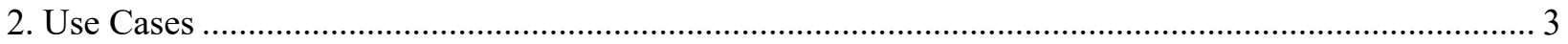

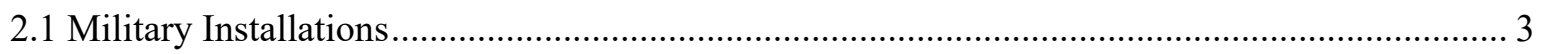

2.1.1 Forward Operating Bases …............................................................................... 5

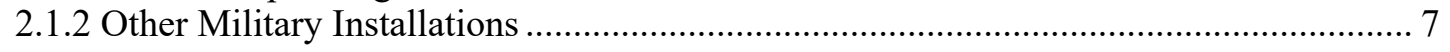

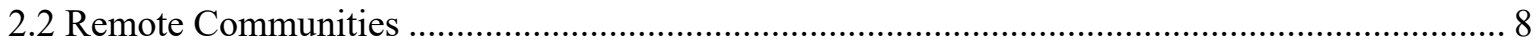

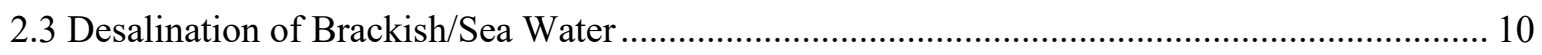

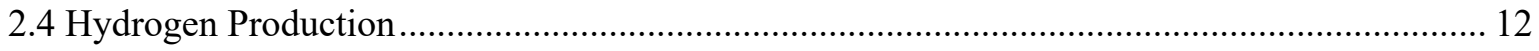

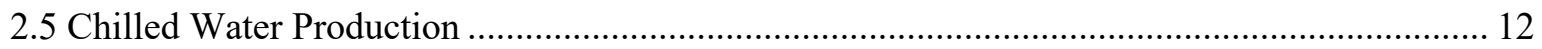

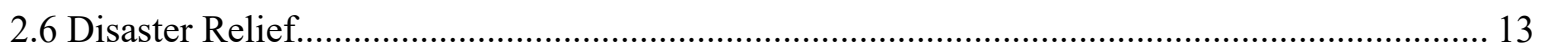

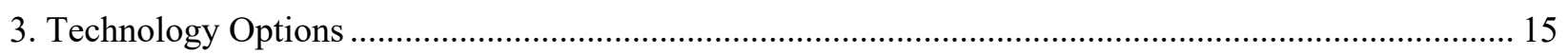

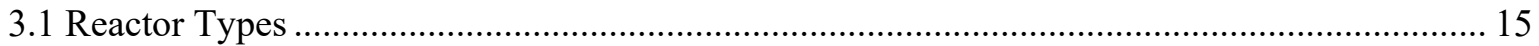

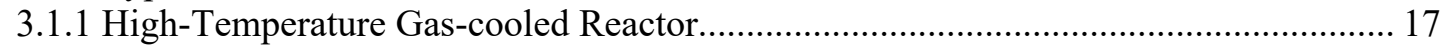

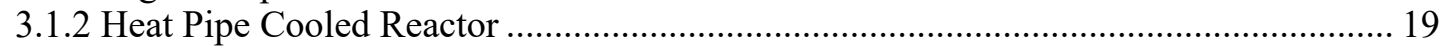

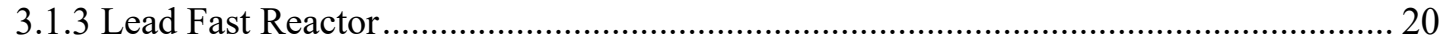

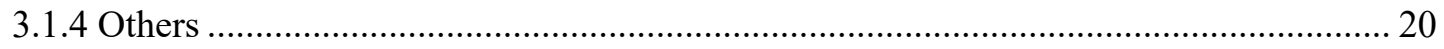

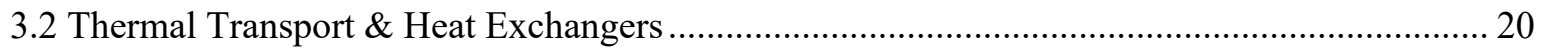

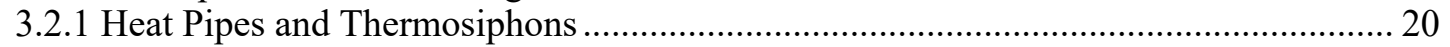

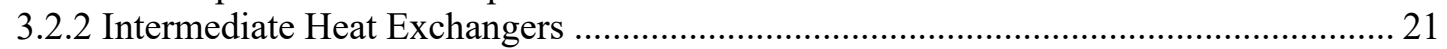

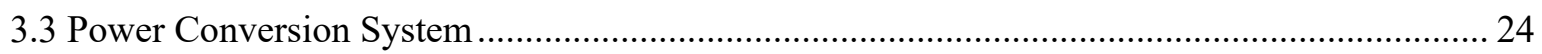

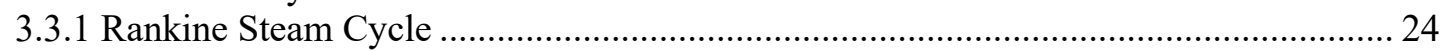

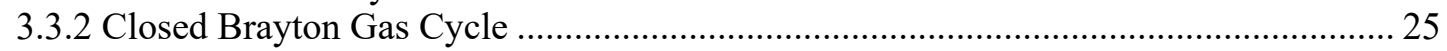

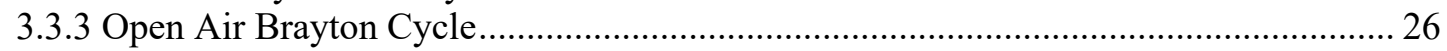

3.3.4 Supercritical Carbon Dioxide Recompression Brayton Cycle ..................................... 27

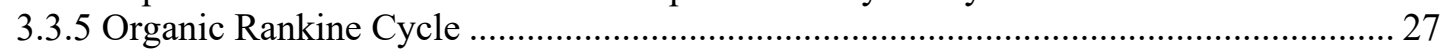

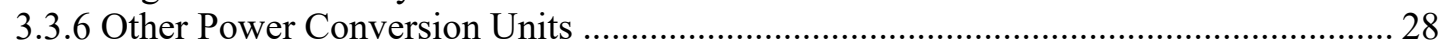

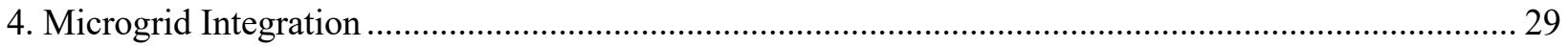

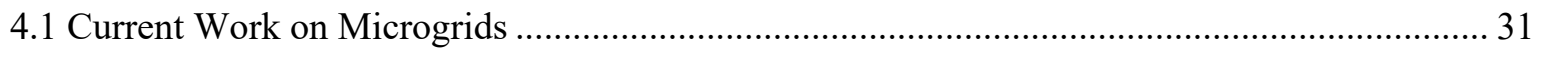

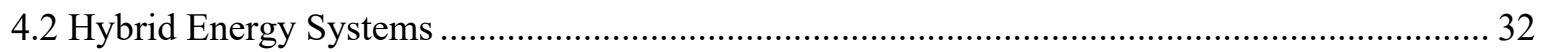

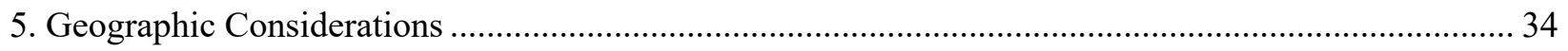

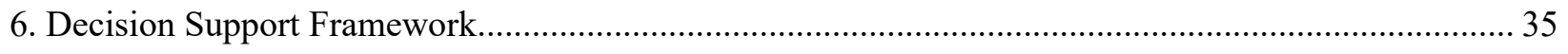

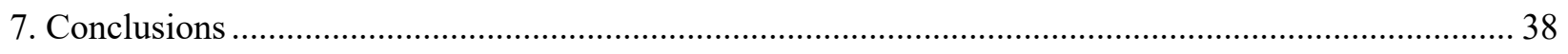

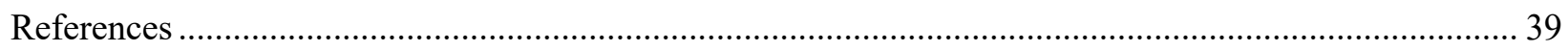




\section{FIGURES}

Figure 2.1. Breakdown of average energy demand at DoD installations in FY-2016 ............................ 4

Figure 2.2. Military fuel consumption history and forecast [8] ........................................................ 5

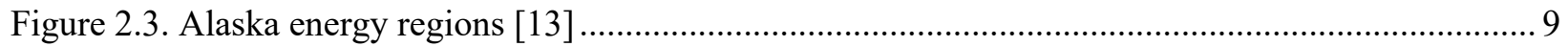

Figure 2.4. Energy generation in Alaska regions averaged over full year [14] ...................................... 9

Figure 2.5. Energy generation in Alaska regions averaged over full year (regions with $<20 \mathrm{MWe}$ ) ......... 10

Figure 2.6. Schematic of basic MSF desalination process ................................................................ 11

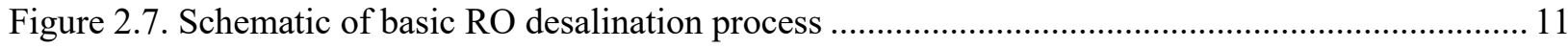

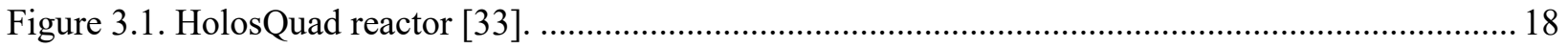

Figure 3.2. Westinghouse eVinci heat pipe cooled reactor concept [36] ............................................... 19

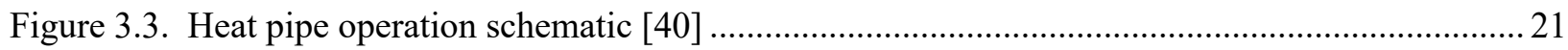

Figure 3.4. Rankine cycle with feed-water heaters and reheat............................................................. 24

Figure 3.5. Closed Brayton cycle with recuperation and intercooling................................................... 25

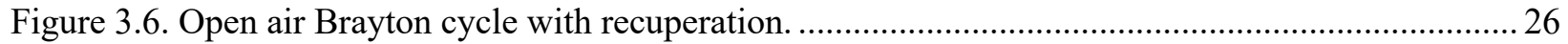

Figure 3.7. Supercritical carbon dioxide recompression Brayton cycle. ….............................................. 27

Figure 4.1. Energy generation methods, use cases, and benefits. ........................................................ 31

Figure 6.1. Decision support framework for microreactor development and deployment ........................ 37

\section{TABLES}

Table 1.1. Relative electric power production of microreactors vs. other reactor types [1] ..................... 1

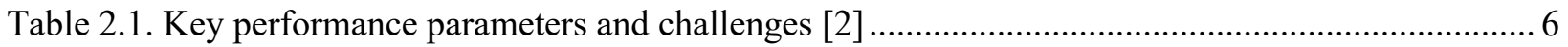

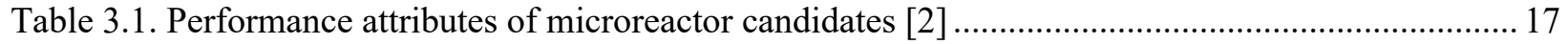

Table 3.2. Boiling temperature of selected heat pipe working fluids ................................................... 21

Table 3.3. Principal features of several types of heat exchangers [43] ................................................. 23

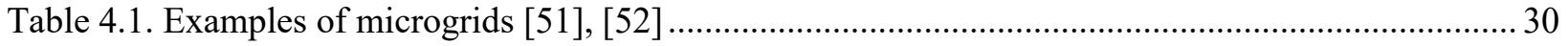

Table 6.1. Motivating factors for microreactor deployment in certain use cases. ................................... 35

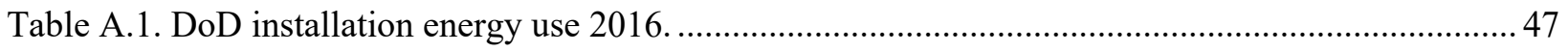

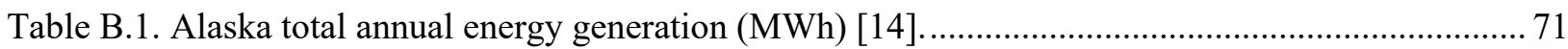

Table B.2. Alaska average energy demand (MW). The annual total values in the table above have been divided by the number of hours in a year $(8760$ hours $)$.................................................. 71 


\section{ACRONYMS}

AEMR Annual Energy Management and Resilience

CNA Center for Naval Analyses

$\mathrm{CO}$ carbon monoxide

$\mathrm{CO}_{2} \quad$ carbon dioxide

CONUS continental United States

DoD U.S. Department of Defense

DOE U.S. Department of Energy

DOE-OE U.S. Department of Energy-Office of Electricity

DOT U.S. Department of Transportation

DSB Defense Science Board

EPZ emergency planning zone

FBCE fully burdened cost of energy

FOAK First of a Kind

FOB forward operating base

GE General Electric

GHG greenhouse gas

GWh gigawatt hour

HALEU high-assay, low-enriched uranium

HIP hot isostatic press

HTGR high-temperature gas reactor

HTSE High-Temperature Steam Electrolysis

HVAC heating, ventilating, and air-conditioning

IED improvised explosive device

IHX intermediate heat exchanger

INL Idaho National Laboratory

IPP independent power producer

K Potassium

kWh kilowatt hour

LANL Los Alamos National Laboratory

LEU low-enriched uranium

LFR lead fast reactor

LOCA loss of coolant accident

LWR light-water reactor

MPa megapascals 
MRL Manufacturing Readiness Level

MSF multistage flash desalination

MWe megawatt electric

MWth megawatt thermal

$\mathrm{Na} \quad$ Sodium

NASA U.S. National Aeronautics and Space Administration

NHES Nuclear Hybrid Energy System

NRC U.S. Nuclear Regulatory Commission

OCONUS outside the continental United States

$\mathrm{OE} \quad$ Office of Electricity

PCU power conversion unit

PIRT Phenomena Identification and Ranking Table

PV photo voltaic

RO reverse osmosis

$\mathrm{SCO}_{2} \quad$ supercritical carbon dioxide

SFR Sodium Fast Reactor

SMR Small Modular Reactor

SPR Special Purpose Reactor

SRL System Readiness Level

TES Thermal Energy Storage

TRISO tristructural isotropic

TRL technology readiness level

U.S. United States

vSMR very Small Modular Reactor 


\section{INTRODUCTION}

A microreactor, also known as a very-Small Modular Reactor (vSMR) or a Special Purpose Reactor (SPR), is designed for use in unique applications where energy generation on the order of mega-watts is needed but otherwise unavailable or prohibitively expensive. Microreactors generally produce less than 20 megawatt thermal (MWth), ${ }^{a}$ are factory manufacturable, easily transportable (e.g., truck, train, plane, or ship), and neutronically simple so as to allow for semi- or fully-autonomous operation. The use cases for the generated energy may call for electricity production, direct use of process heat, or both. Table 1.1 shows the electric power production potential of microreactors relative to other types of reactors [1].

Table 1.1. Relative electric power production of microreactors vs. other reactor types [1].

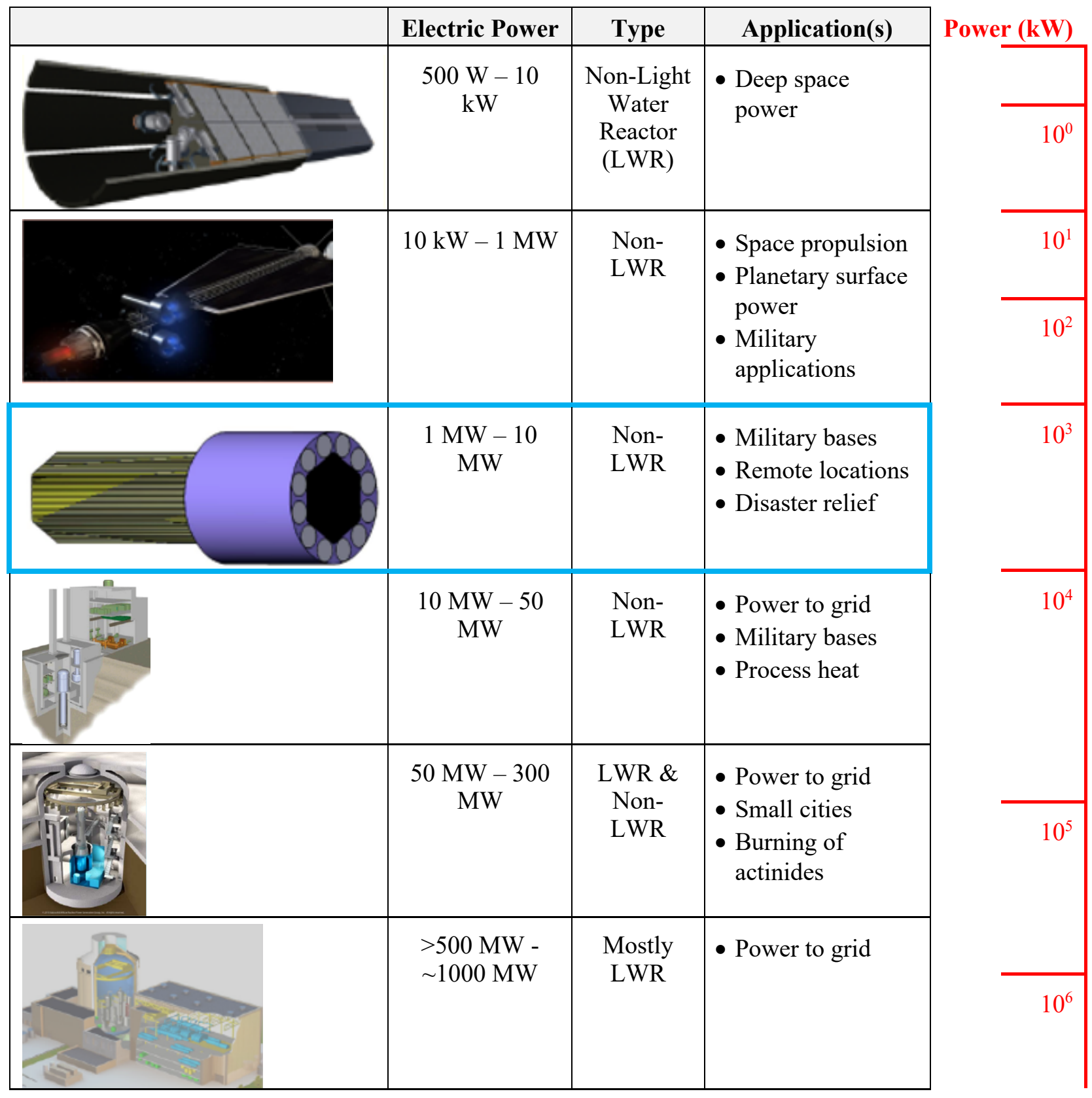

a The limit of $20 \mathrm{MW}_{\text {th }}$ allows for classification of microreactors as Hazard Category 2 per 10 CFR 830, DOE-STD-1027. 
The objectives of this report are as follows:

1. Outline the expected use cases, including the needs and constraints present in each use case. This includes considerations for reactor deployment, geographic factors, and integration with existing infrastructure.

2. Examine the known microreactor technologies currently under development and the associated sub-system technologies, including interfaces.

3. Develop a decision support framework for examining the potential performance of a given microreactor in a defined use case.

4. Discuss the integration of a microreactor with a microgrid.

\subsection{Background}

There is an increasing need for more reliable and readily available energy in special purpose applications. Possible applications include, but are not necessarily limited to, military installations, remote communities, and industrial processes. Mobile power for emergency response may also be considered among these relatively small, but high consequence, markets. Typical power needs in these use cases range from 1 to 10 megawatt electric (MWe). In many current applications, power generation at this scale is achieved through the use of diesel generators. However, increasing costs and supply chain constraints have prompted a desire to examine other options to ensure energy availability and reliability.

In combat scenarios, the fully burdened cost of energy (FBCE) for truck-delivered fuel is estimated to range from $\$ 10$ - $\$ 50$ per gallon [2]. For air-dropped fuel, this cost increases to as much as $\$ 400$ per gallon [3]. In remote Alaskan villages, fuel costs can rise to as much as $\$ 10$ per gallon, with electricity costs exceeding 40 cents per kilowatt hour $(\mathrm{kWh})$ [4]. Additionally, there is renewed interest in using nuclear power for certain process heat and industrial applications, such as water desalination [5]. These economic and technical realities have motivated a desire for developing other methods of energy production. Microreactors could be ideal for many of these scenarios due to their potentially long-term reliability, ease of deployment, and relatively abundant energy production. This has led several national laboratories and private companies to explore the development and deployment of microreactor concepts.

While several concepts are under development, none of them have been constructed. There is a desire to begin operation of a First-of-a-Kind (FOAK) demonstration microreactor in the early $2020 \mathrm{~s}$. This aggressive goal will require the use of high technology readiness level components, as well as fuels and materials that are already qualified for use in nuclear fission environments. Additional rapid maturation of integration and control technologies will also be required. Later systems may pursue advanced materials, advanced fuels, and novel heat exchangers in order to achieve higher performance, greater efficiency, and lower cost. 


\section{USE CASES}

Microreactors are primarily intended for non-traditional applications of nuclear energy. Specific deployment opportunities may include provision of heat and electrical power to remote commercial and industrial applications, remote civilian municipalities, or remote or islanded military installations. Currently anticipated requirements for each of these use case categories are summarized in the following section.

The specific use cases outlined here can be characterized by three general use scenarios:

1. Remote Sites

- Meet the needs of remote locations outside the continental United States (OCONUS), and/or fixed Department of Defense (DoD) bases (e.g., Alaska, Guam, Northern Canadian Communities).

- Provide combined heat and power.

- Support critical loads (e.g., hospitals and radar stations).

- Microreactors would displace diesel or JP-8 fueled generators.

2. Mobile Power

- Mining operations and/or 'mobile' DoD bases such as Forward Operating Bases (FOBs).

- Provide combined heat and power.

- Reactors design should be mobile rather than just transportable.

- Microreactors would displace diesel or JP-8 fueled generators.

3. Renewable Microgrids

- Provide baseload power to stabilize the variability of renewable wind and solar energy.

- Displace 'fast-ramp' open cycle gas turbine generators.

- Could potentially be used to decrease battery storage needs.

\subsection{Military Installations}

United States (U.S.) DoD installations are working towards ensuring greater energy security through the addition of on-site renewable energy to reduce reliance on the grid. Given that the average energy use of most DoD installations is less than $20 \mathrm{MWe}$, microreactors may be an option for future energy production. Figure 2.1 shows the breakdown of average energy demand at DoD installations in 2016. The data is based on the DoD Annual Energy Management and Resilience (AEMR) Report for FY2016 [6]. Additional detail is provided in Appendix A. 


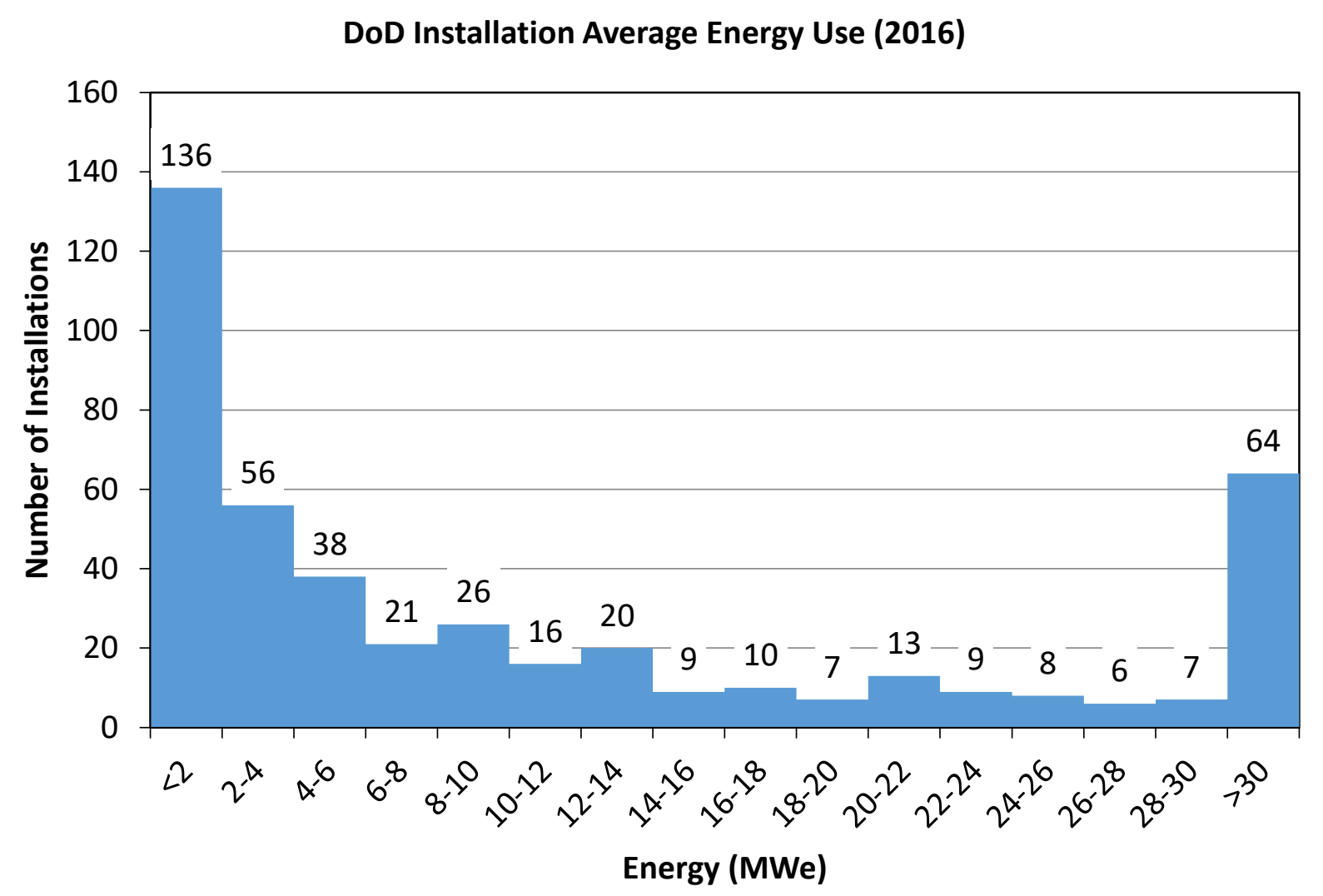

Figure 2.1. Breakdown of average energy demand at DoD installations in FY-2016.

Not all of the DoD installations noted in Figure 2.1 or Appendix A are suitable for a nuclear reactor. The decision matrix determining which facilities may benefit from MW scale, on-site nuclear power will be evaluated in future studies that engage energy planners within DoD. It is worth noting that, in general, the level of energy use at these locations is within the capability range of microreactor systems.

The use of Small Modular Reactors (SMRs) at military installations was examined in a 2011 study by the Center for Naval Analyses (CNA) for the DoD [7]. While the study showed that SMRs can meet DoD targets for energy reliability and clean energy production, several issues were identified. Many of these issues related to the size of the SMR plant, which would be $\sim 50 \mathrm{MWe}$. This plant size would require extensive effort for siting. Additionally, the cost for a FOAK plant would likely make the plant economically unfeasible.

Microreactors avoid or minimize concerns regarding potential impact to the public due to their much smaller footprint and more simplistic design. As a result of the reduced source term and radionuclide inventory for microreactors relative to large-scale reactors, the associated emergency planning zone (EPZ) could be as close as the containment boundary. The small size of microreactor plants is additionally expected to simplify the siting process. Particularly in the case of a FOAK reactor, licensing and siting could be further simplified with construction at an existing U.S. Department of Energy (DOE) site. Public-private cooperation can help keep FOAK microreactor costs lower than those previously anticipated with SMR plants. 


\subsubsection{Forward Operating Bases}

FOBs require significant fuel supplies to maintain operations. As of 2007, fuel consumption was approximately 22 gallons per soldier per day in Iraq and Afghanistan, a significant increase over past engagements. Figure 2.2 shows the historic trend of military fuel consumption.

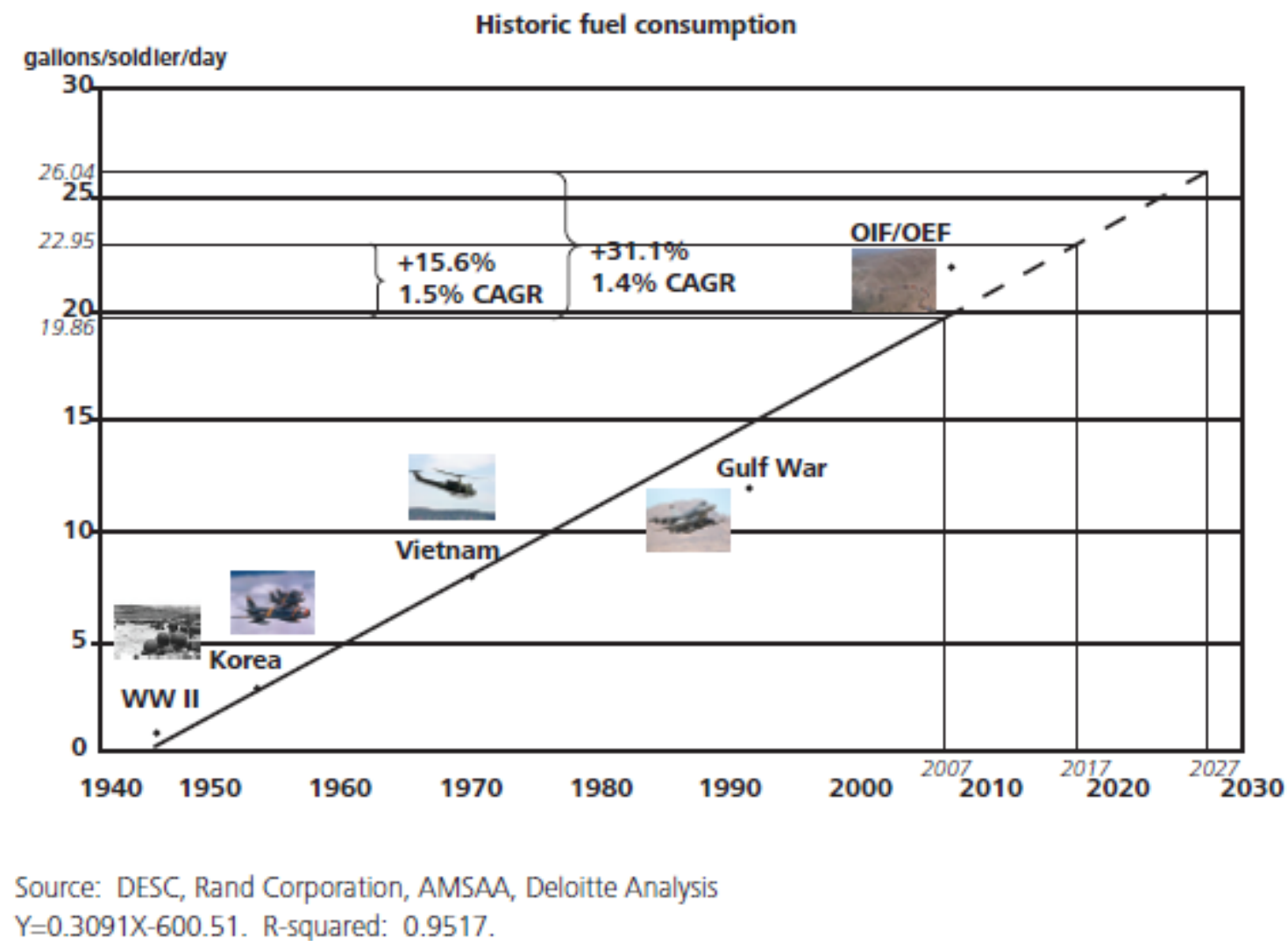

Figure 2.2. Military fuel consumption history and forecast $\mathrm{t}^{\mathrm{b}}[8]$.

Diesel fuel is used not only for operating vehicles, but also for electricity generation at FOBs. To transport fuel to a FOB, a fuel convoy is used. These convoys are susceptible to a variety of hazards ranging from weather and traffic accidents to attacks and disruption from roadside improvised explosive devices (IEDs). These logistical hazards have been a significant source of casualties in the recent conflicts in Iraq and Afghanistan. Based on history, the need for energy in future conflicts is only expected to grow [8].

A recent report from the Defense Science Board (DSB) Task Force on Energy Systems for Forward/Remote Operating Bases considered the potential impact of alternative energy on fuel consumption. The use of alternative energy sources for base support would result in a significant reduction, but not an elimination, of fuel demand. The DSB Task Force also found that many renewable energy sources, such as solar and wind, are limited by their variability and the large footprint necessary to produce an adequate amount of electricity [2].

Microreactors tend to address many of the concerns raised by renewable energy sources. Microreactor systems produce a stable, continuous supply of abundant energy in a relatively small footprint. The DSB report noted the potential for microreactors to enable new capabilities, since the bases would switch from a scarce energy supply to an abundant one [2]. An abundance of energy opens up the possibility for using

b AMSAA: Army Materiel Systems Analysis Activity; CAGR: Compounded Annual Growth Rate; DESC: Defense Energy Support Center; OEF: Operation Enduring Freedom; OIF: Operation Iraqi Freedom; WW II: World War II 
nuclear-generated heat for synthetic fuel production. This would further reduce the reliance on fuel supply convoys and therefore reduce the casualties associated with protecting convoys.

A summary of requirements from the DSB report is reproduced here [2]:

- Outputs: Modular and scalable units capable of producing 2-10 MWe and potentially useful heat (which would facilitate water or fuel production)

- Size and transportability: $25-40$ tons; transportable by truck or C-17 aircraft

- Ultimate heat sink: Ambient air (in contrast to conventional water-cooled reactors); capable of passive cooling

- Time to install: $12-72$ hours

- Refueling: Refueling should not be required more than annually; fresh and used fuel should be transportable by air, sea, and ground

- Time for planned shutdown, cool down, disconnect, and removal: 6 hours to 7 days

- Operation: Autonomous or semiautonomous operations with minimal manning to monitor overall health of the vSMR

- Response to emergency: Capable of immediate shutdown and passive cooling

- Health and safety risks: No net increase in risk to public, military personnel, environment; no net increase in consequences of adversary attack

- Proliferation risk: No net significant increase in proliferation risk

In addition to these requirements, the DSB report also summarizes some key performance parameters from an Idaho National Laboratory (INL) report, which are reproduced in Table 2.1 [2].

Table 2.1. Key performance parameters and challenges [2]

Key Performance Parameter (KPP)

Transport fresh and used fuel by air, sea, rail, and highway.

No significant increase in FOB threat consequence effects, e.g., avoid unacceptable radiological consequences.

Transportable by C-17 aircraft.

Installed and operating within 72 hours.

Shutdown, cool down, disconnect and transport to another location in less than seven days.

Capable of immediate shutdown and passive cooling.

\section{Challenge}

Need a nuclear energy system capable of air transportation, while addressing highly radioactive source terms and large residual heat loads.

Need a nuclear energy system design that mitigates toxic and radioactive dispersal and related consequences from credible transport or operation accidents or design basis attacks, e.g., ballistic, IED, direct fires that breach the system.

Need a nuclear energy system that can be transported to FOBs worldwide by military transport.

Need a nuclear energy system that is agile, quickly set-up and operating.

Need a nuclear energy system that is agile and able to move with the FOB, i.e., it is not the "long pole in the FOB tent."

Need a nuclear energy system that is inherently safe, with no negative outcome if all active systems and controls are lost, e.g., due to attack. 
Table 2.1 (continued)

No significant increase in risk to the health and safety of the public, military personnel or to the environment.

Greater than one year refueling cycle.

No proliferation risk.
Need a nuclear energy system that does not result in a significant increase in risk to the health and safety of the public, military personnel nor to the environment, relative to the risk associated with normal human activity.

Need a self-contained nuclear energy system that dramatically reduces the number of energy related convoys.

Need a nuclear energy system that is designed to minimize proliferation risk by reducing fuel access opportunity, reducing fuel attractiveness and avoiding production of attractive fuel.

Need to adjust to FOB size and load demand.

\subsubsection{Other Military Installations}

A recent DoD report (2017) discusses the mandate to increase the use of renewable energy at military installations. While significant progress has been made, current targets for renewable energy utilization are being missed. The report also discusses the potential for SMRs at military installations. The report states that SMRs, which generate at least $50 \mathrm{MWe}$, are too large for a single military installation and should therefore be considered by regional utility providers. There are additional concerns about financial and technical hurdles to SMR deployment. DoD also doubts the ability to deploy prior to 2025 [6].

A 2011 report by CNA considered nuclear power, and SMRs in particular, for military applications. The report concluded that while nuclear power can assure abundant energy for critical functions, there are several drawbacks. These included siting of reactors, as well as economic viability. In particular, the FOAK expenses were estimated to be in the hundreds of millions of dollars. Additionally, the cost of electricity was estimated to be slightly higher than the projected average retail price for industrial users in the US. Ultimately, the report did consider SMRs feasible, particularly in remote locations for electricity and heat, if the concerns related to licensing and FOAK costs can be addressed [7].

Microreactors can reduce the need for diesel for electricity production at military installations. Additionally, the reactors can be used to supplement other needs, such as district heating and water desalination. In cases where a military installation already has sufficient access to an external power supply, a microreactor could be used for backup power of critical infrastructure. The specific needs of individual military installations will need to be considered on a case-by-case basis. A case study to assess energy system needs at high priority installations will help to define the deployment criteria.

Given their significantly smaller footprint and lower power generation level, microreactors can address many of the concerns DoD raised for SMRs.

- Simplicity: Microreactors are designed from the start to be lower cost and simple, with reduced operations and maintenance overhead. Additionally, they are designed to continuously operate for several years without refueling.

- Power output: Power output on the order of $10 \mathrm{MWe}$ is in line with the average demand of many military installations. This removes the need for a reactor to be connected to an outside regional grid to distribute excess energy. 
- Technology readiness: While some development is still needed in microreactor technology, the designs under consideration for initial deployment are largely based on known technologies with high technology readiness level (TRL).

- Licensing: The licensing path still needs clarification. The smaller reactor size should simplify siting considerations and simplify some parts of the licensing process. The details of microreactor licensing are currently being defined by the U.S Nuclear Regulatory Commission (NRC) and private sector stakeholders.

\subsection{Remote Communities}

Remote communities provide unique challenges for reliable energy generation. In rural Alaska, electric power can vary from $\$ 0.50$ to $\$ 1.50$ per $\mathrm{kWh}$, and heating fuel can vary from $\$ 1.40$ to $\$ 10.00$ per gallon [9], [10]. The harsh climate means that fuel can only be delivered during warmer months of the year, with diesel providing more than $90 \%$ of electric power in rural areas. In November of 2011 , the town of Nome Alaska was scheduled to receive its final fuel shipment of the year [11]. The shipment of heating fuel, diesel, and gasoline is necessary for the town to survive the harsh winter. When a massive storm hit earlier than expected, the town was iced in prior to arrival of the fuel shipment. Without adequate fuel to survive the winter, there was the potential of evacuating until spring. Luckily, arrangements were made to have the fuel brought in on a double-hulled barge, with the help of a U.S. Coast Guard icebreaker.

In order to diversify and increase the resilience of power generation systems, Alaskan villages are turning to microgrids. In Cordova, Alaska, a microgrid system is being installed which will reroute power to ensure that critical services are always supplied. The system is designed to be make automated decisions about power transmission, allowing it to reconfigure to accommodate changes in the grid [12].

Microreactors have the potential to revolutionize how energy is produced and distributed in remote locations. The communities generally have significant fuel costs and are often isolated from much of the world for long periods each year. Their limited accessibility, infrastructure, and low population density introduce unique requirements for reliable power and heat generation. Due to its current reliance on microgrids which use fossil and renewable energy sources, Alaska is a prime location where microreactors could have a major impact.

Alaska is divided into 12 land-based regional corporations and over 200 village corporations. Figure 2.3 shows the geographic boundaries for the land-based regions and how they overlap with 11 energy planning regions [13]. Data from the Alaska Energy Data Gateway was used to examine total annual energy generation for the years 2008 through 2013 in each of the 11 energy regions. Appendix B summarizes this data, showing the annual average demand when divided by the number of hours in a year ( 8760 hours). Figure 2.4 and Figure 2.5 show this average energy generation rate for each region in each year. 


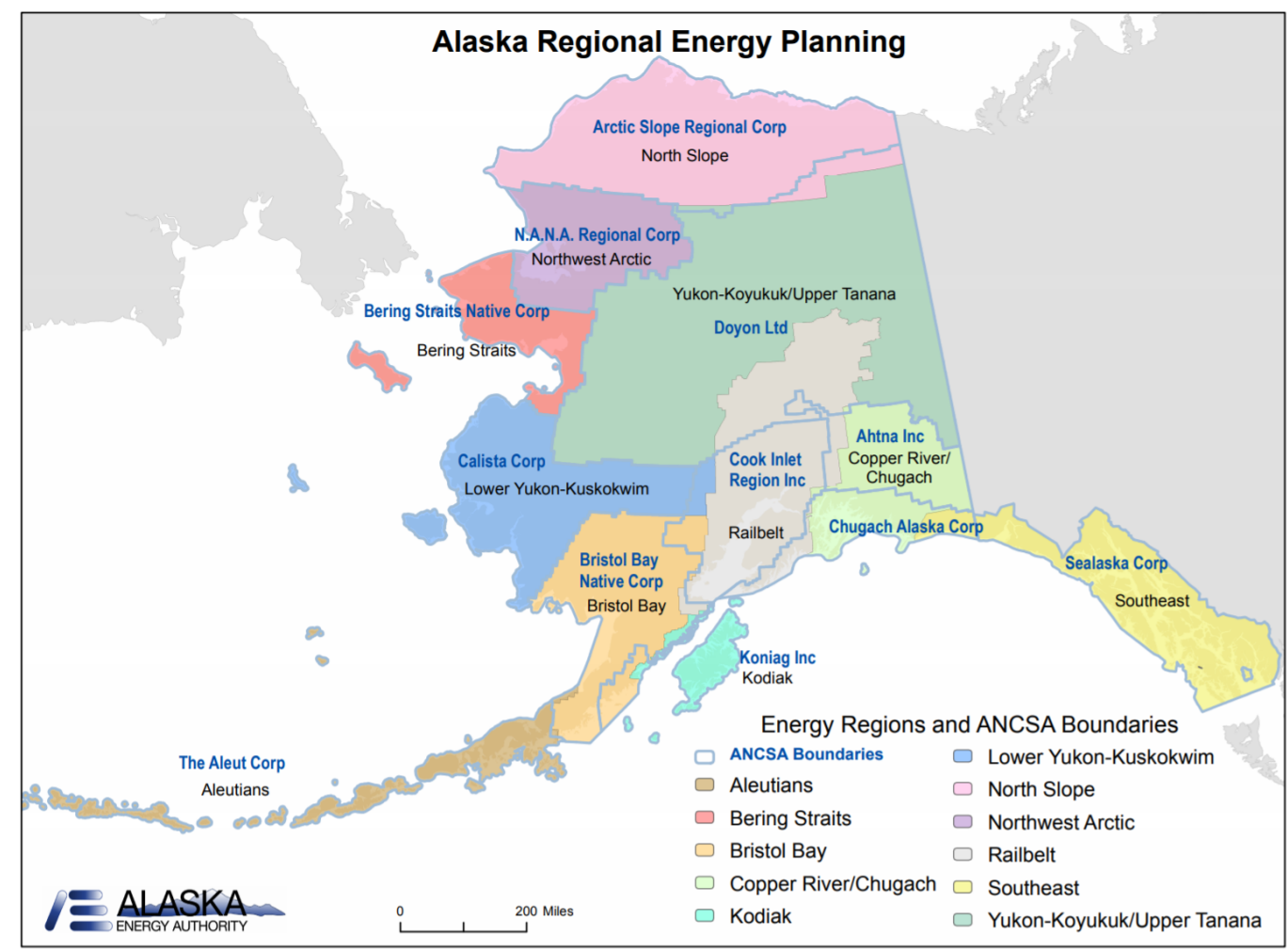

Figure 2.3. Alaska energy regions [13]

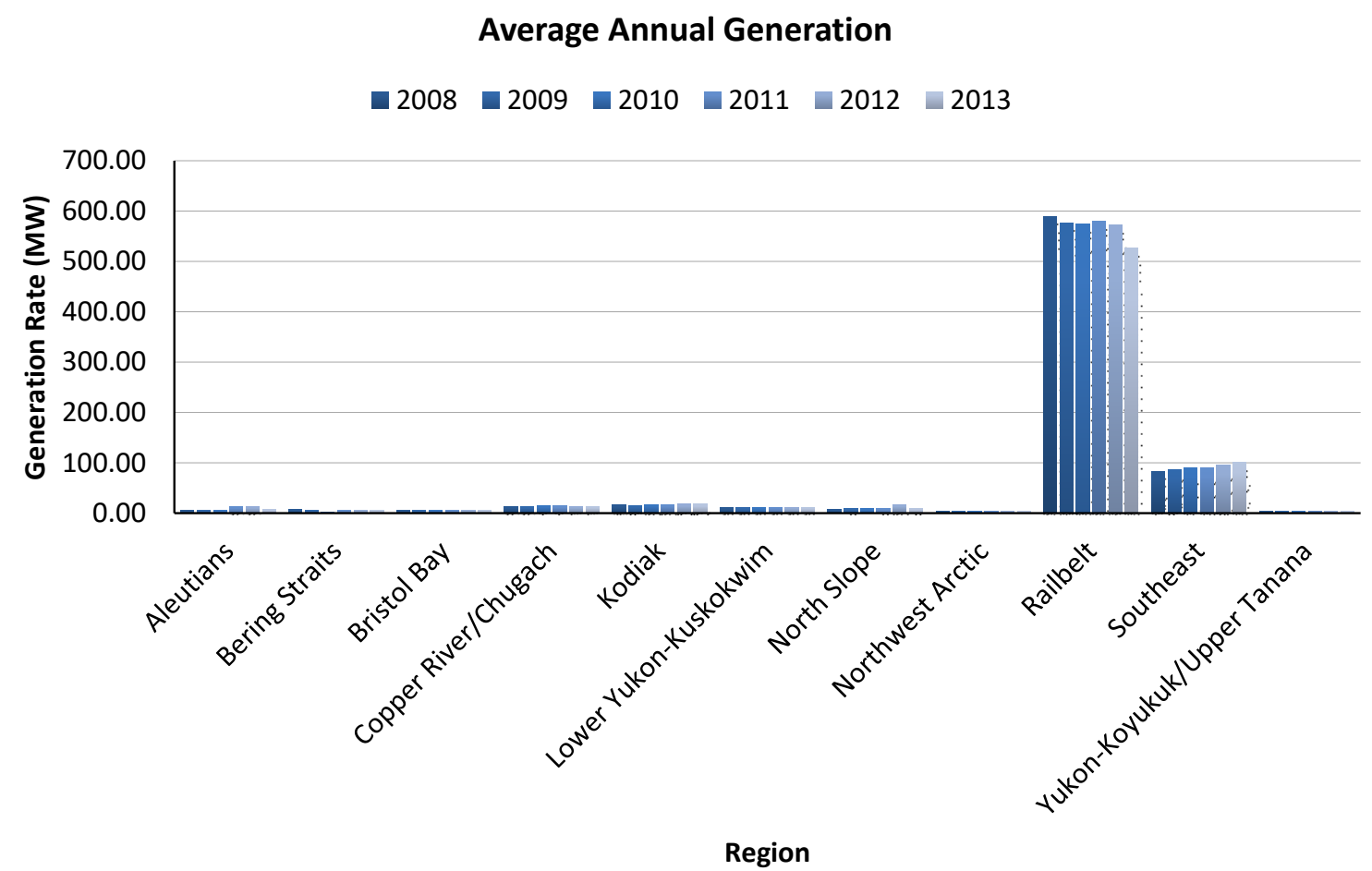

Figure 2.4. Energy generation in Alaska regions averaged over full year [14] 


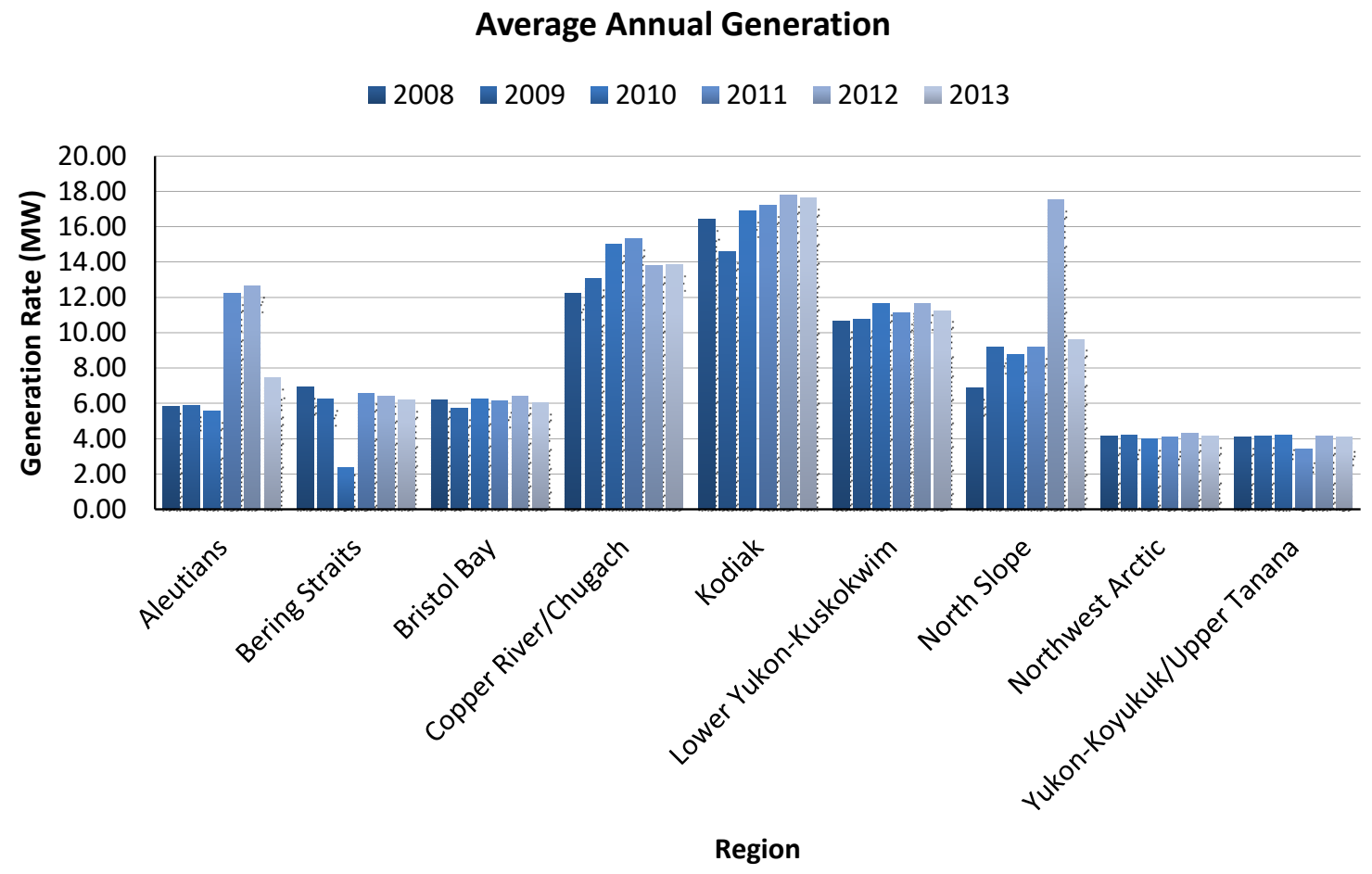

Figure 2.5. Energy generation in Alaska regions averaged over full year (regions with $<20 \mathrm{MWe}$ )

The average power demand is less than 18 MWe in all but two of the energy regions. Hourly and seasonal variations in demand mean that actual demand at any given time is likely to be significantly different from these values. However, the data in Figure 2.5 show an opportunity for microreactors to integrate into microgrids. Microreactors that work in concert with other energy sources through a smart microgrid such as the one being deployed in Cordova, have the potential to provide these remote locations with abundant rather than scarce energy supply.

\subsection{Desalination of Brackish/Sea Water}

A potential alternative energy application is the desalination of sea water. This would be a particularly useful application in areas such as Southern California or the Southwestern U.S., where availability of potable drinking water is an increasing concern. To ensure adequate water supplies, desalination plants such as the Claude "Bud" Lewis plant in Carlsbad are being brought online in Southern California [15], [16].

For desalination plants with a capacity of $4000 \mathrm{~m}^{3}$ per day or more, the two main technologies available are multistage flash (MSF) desalination and reverse osmosis (RO). As of 2000, MSF accounted for $69 \%$ of high capacity plants, while RO accounted for $23 \%$ [17]. MSF desalination is based on heating seawater in a brine heater to approximately $100^{\circ} \mathrm{C}$. The hot brine then enters a flash chamber under vacuum. Since the water entering the chamber is above the boiling temperature at vacuum, part of the water flashes to steam. The steam rises to condensing coils where it cools and condenses to fresh water. The process is illustrated in Figure 2.6. 


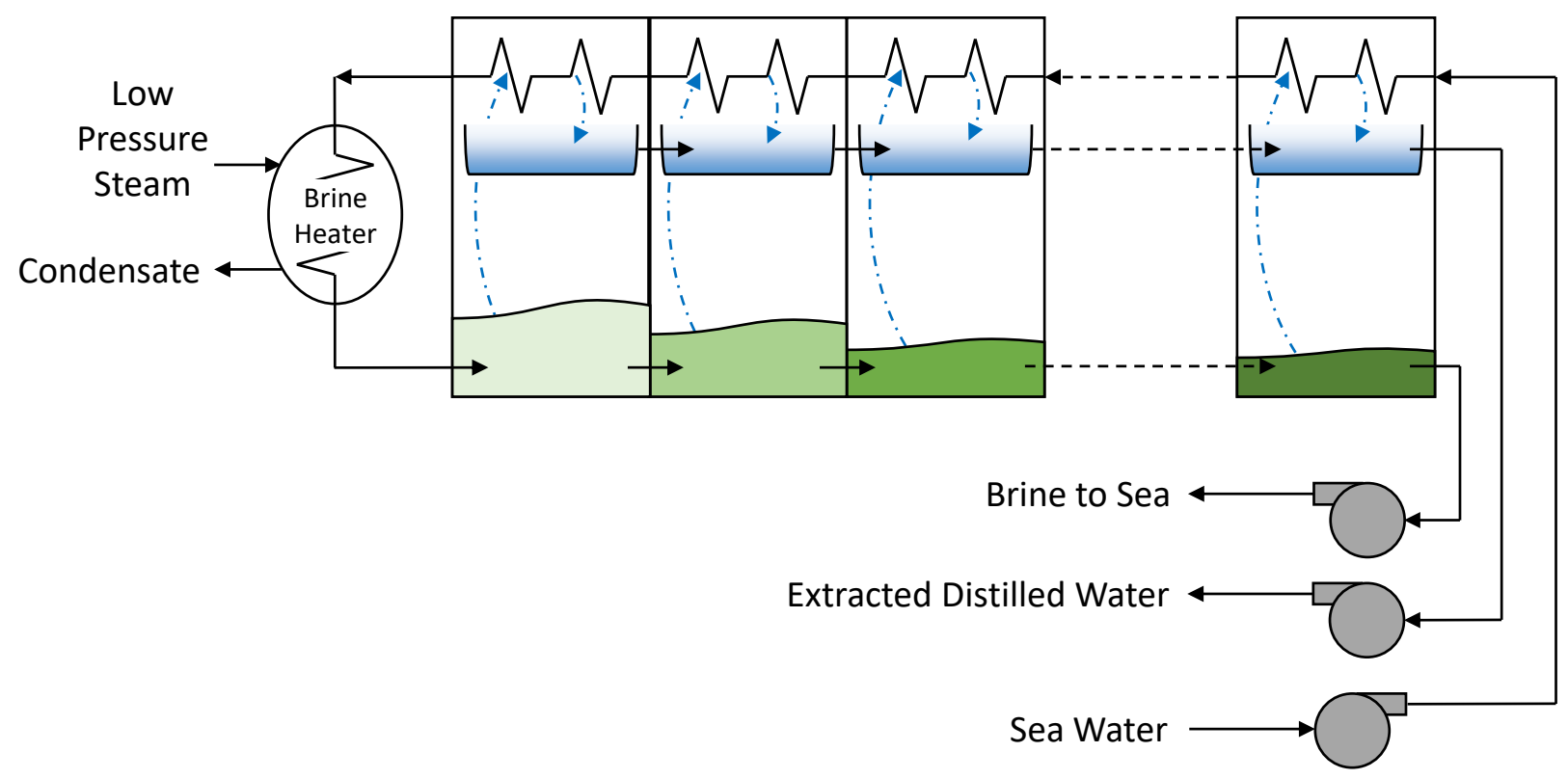

Figure 2.6. Schematic of basic MSF desalination process

RO desalination works by passing water at high pressure through fine membranes which allow only water molecules to pass. A typical RO plant works in two stages, the first being a pretreatment stage where chlorine and other chemical additives are used to remove biological contaminants, as well as control the $\mathrm{pH}$ and hardness of the water. The water is then sent to the membrane filtration system where high pressure forces the water molecules through the membranes and into an inner collection tube. The RO desalination process is shown in Figure 2.7.

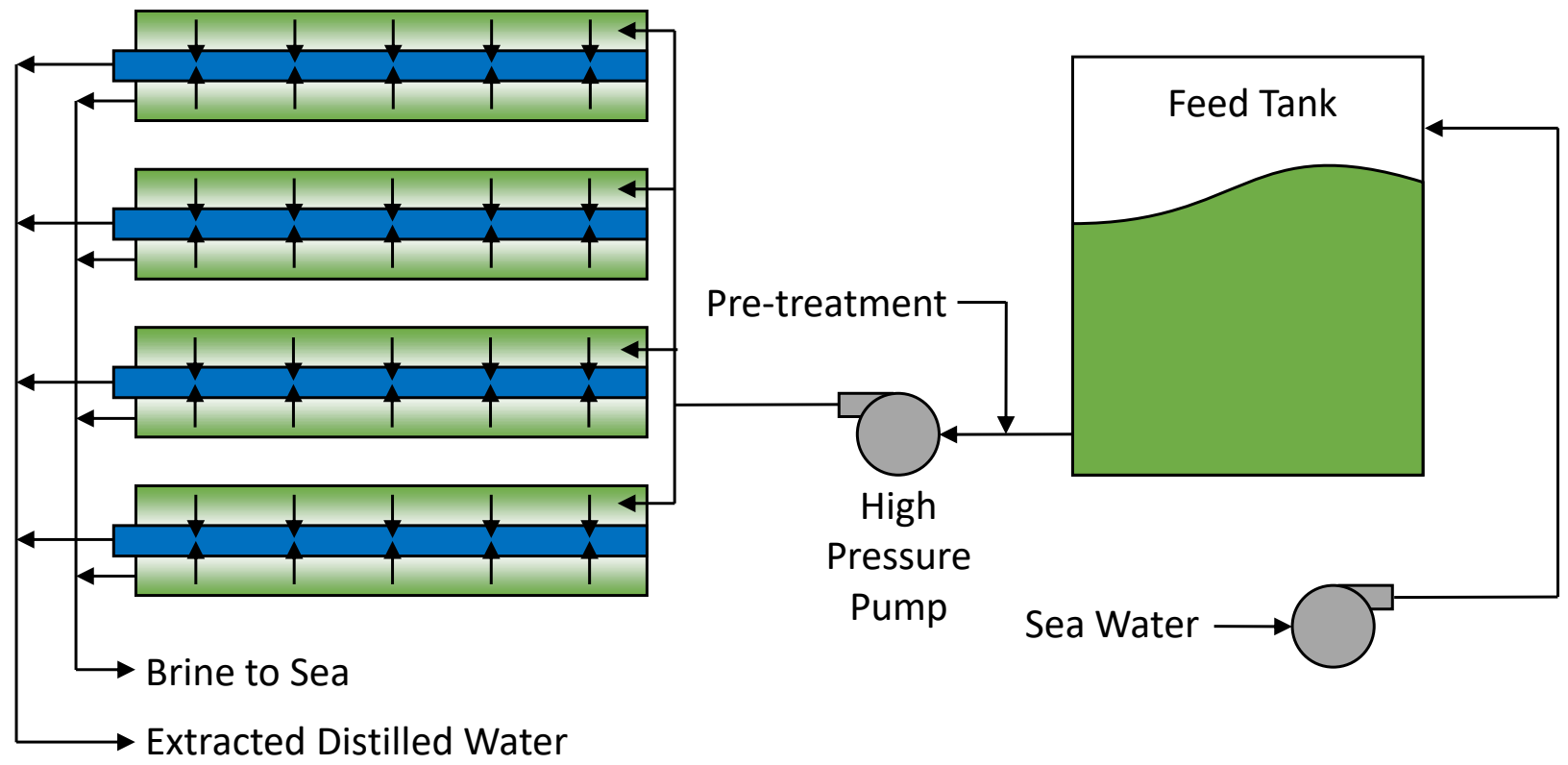

Figure 2.7. Schematic of basic RO desalination process

MSF is a proven technology for water desalination. It is a simple and extremely reliable process that requires no moving parts other than pumps. Unfortunately, MSF is more energy intensive than current RO plants, requires a direct steam connection to the power plant, and typically runs at full capacity to limit 
potential system instabilities [18]. These challenges limit MSF applications when steam shedding is being used as a load leveling strategy.

RO has the benefit of consuming less energy than MSF. RO also does not need a direct steam connection to the power plant, as it only requires electric energy to run pumps and has simple start/stop operating capability [18]. Since RO is operated in modules, operation can be staged to take advantage of available excess energy instead of the all or nothing operation of MSF. These properties make RO a highly attractive secondary energy application for microreactors in remote locations.

\subsection{Hydrogen Production}

Excess thermal and electrical energy can be used for hydrogen production. The anticipated development and deployment of fuel cell technology and infrastructure into the transportation sector will create substantial additional demand for hydrogen. One of the motivations to switch to a hydrogen-based infrastructure is to reduce greenhouse gas (GHG) emissions. However, significant GHG reduction will only occur if the hydrogen is produced from carbon-free sources.

Current large-scale hydrogen production is accomplished by stripping hydrocarbon fuel via the steam-methane reforming process shown in Eq. 1 [19]. In steam-methane reforming, methane reacts with steam in the presence of a catalyst to produce hydrogen and carbon monoxide (CO). In a subsequent "water-gas-shift reaction," the $\mathrm{CO}$ and steam are reacted using a catalyst to produce carbon dioxide $\left(\mathrm{CO}_{2}\right)$ and hydrogen, as shown in Eq. 2.

$$
\begin{gathered}
\mathrm{CH}_{4}+\mathrm{H}_{2} \mathrm{O}+(\text { heat }) \rightarrow \mathrm{CO}+3 \mathrm{H}_{2} \\
\mathrm{CO}+\mathrm{H}_{2} \mathrm{O} \rightarrow \mathrm{CO}_{2}+\mathrm{H}_{2}+(\text { small amount of heat })
\end{gathered}
$$

A byproduct of this reaction is $\mathrm{CO}_{2}$, which does not meet the GHG reduction standards established in the Paris agreement [20]. Fortunately, an alternative clean energy source of hydrogen with zero $\mathrm{CO}_{2}$ emissions comes from the dissociation of water via conventional (i.e., low temperature) electrolysis and High Temperature Steam Electrolysis (HTSE) [21]. HTSE is $40 \%$ more efficient than conventional electrolysis, but requires temperatures of $\sim 800^{\circ} \mathrm{C}$. HTSE uses approximately $79 \%$ electrical energy and $21 \%$ thermal energy [22], [23]. While this option's usefulness may be limited in remote locations due to limited hydrogen production needs, this is a viable option for small microgrid deployments. Note that hydrogen may also be used within a number of industrial processes that could be of interest to remote facilities.

\subsection{Chilled Water Production}

Chilled water is used in large manufacturing facilities, college campuses, and district heating and cooling systems to satisfy cooling demands. During warmer months of the year, a large portion of a facility's electricity demand is generated from heating, ventilation, and air-conditioning (HVAC) equipment. Because building cooling loads regularly peak during the early to late afternoon hours, the HVAC equipment is sized to accommodate these peak loads. At night or during early morning hours when cooling loads are low, excess chiller capacity exists. Moreover, these facility cooling loads often coincide with peak electricity demands, thereby putting further strain on utilities. Thermal Energy Storage (TES), in the form of chilled-water storage, is a way to combat peak cooling loads by shifting them from on-peak to off-peak hours [24].

Stratified chilled-water storage tanks have emerged as an effective option for storing chilled water [25]. In a stratified chilled-water storage tank, warm and cold water are stored in the same vessel with no structural interface. Instead, differences in density between cold and warm water cause a thin thermocline, or sharp temperature gradient, to form. Excess chilled water, produced when facility cooling demands are low, is deposited in the bottom of the tank via diffusers. Because the tank is a constant volume device, charging the tank with cold water means simultaneously removing warm water from the top of the tank to 
be sent to the chillers. Conversely, discharging the cold water to be used during times of peak facility cooling loads results in warm water being deposited in the top of the tank. Therefore, a fully charged tank implies the tank is full of chilled water, while a fully discharged tank implies the tank is full of warm water.

A previous case study examined using stratified chilled-water storage in conjunction with centrifugal electric chillers to offset cooling loads synonymous with a large office space or college campus in a Nuclear Hybrid Energy System (NHES). Results demonstrated that chilled-water storage can shift cooling loads to off-peak hours and help promote more steady-state reactor operation. Another option for cooling water involves the use of single effect, lithium bromide absorption chillers, which use steam less than 205 $\mathrm{kPa}(15 \mathrm{psig})$ or hot water and the affinity between an absorbent and a refrigerant to create a chilling effect [26].

Absorption chillers become particularly attractive when a source of waste heat that would normally be rejected to the environment or some other low-temperature sink is available. In a NHES, low-pressure steam can be diverted from waste heat reservoirs or low-pressure sections of the energy conversion cycle to absorption chillers to make chilled water for facility cooling.

\subsection{Disaster Relief}

Any power source which is to be used for disaster relief needs to be readily available, portable either by ship or aircraft, be capable of accommodating variable loads, and employ passive safety systems.

Temporary and emergency power generation in areas impacted by natural disasters has historically been met provided by diesel generators. Diesel generators, like most generators, simply require transport to the disaster area and a fuel supply. However, in areas affected by natural disasters, fuel supply can be limited. Natural gas lines tend to break during earthquakes [27], and diesel transport can become limited during major storms due to inundated roadways. A system devoid of refueling or cooling requirements during emergency scenarios is ideal.

Following Hurricane Maria's devastation across the Caribbean, and particularly in Puerto Rico, DOE Secretary Rick Perry stated during a panel discussion at a National Clean Energy Week event in Washington, D.C. that small nuclear power plants are the kind of "innovation" he would like to "expedite" for Puerto Rico's rebuild. He further stated:

"Wouldn't it make abundant good sense if we had small modular reactors that literally you could put in the back of a C-17 aircraft, transport it to an area like Puerto Rico, and push it out the back end, crank it up, and plug it in?"

"Hopefully we can expedite that." [28]

For a $5 \mathrm{MWe}$ diesel system to run nonstop for three days, it would require approximately 25,000 gallons of fuel [29]. The typical large tanker truck holds up to 9,100 gallons of fuel, meaning that over those three days, three tanker trucks would be required. Additional challenges are encountered when supplying to remote locations such as Puerto Rico. This requirement further increases shipping and electric supply costs. Microreactor technologies that are "plug and play" could potentially carve out a niche in these challenging situations due to their lack of fuel refueling requirements. While a microreactor would likely not be able to supply power to all of a disaster stricken region, it could provide ample energy for emergency crews and critical infrastructure such as hospitals.

A challenge to be considered for microreactors is removal after normal operations are restored. The reactors will need to remain in a shutdown mode to allow decay heat to dissipate for some period of time prior to transport. Generally, after a period on the order of one week, a decay heat exchanger should be adequate to maintain cooling for transport.

The key performance parameters and challenges for FOBs summarized in Table 2.1 are generally applicable to disaster relief scenarios. These parameters emphasize the need to easily transport a reactor 
by aircraft and have it operational in a short period of time. Additionally, the capabilities to scale output and ensure passive cooling are critical. Other parameters, such as the requirement to remove a reactor within a week, may be less critical in disaster relief. 


\section{TECHNOLOGY OPTIONS}

Design and construction of microreactors will require the development and interfacing and several technologies. The reactor, heat exchangers, power conversion systems, control systems, and other technologies must be mature and their interactions with each other must be well understood. Starting with a specific technology and working up to the full system, the maturity of various reactor designs can be assessed through the following metrics:

- Technology Readiness Level (TRL)

- Manufacturing Readiness Level (MRL)

- System Readiness Level (SRL)

Each reactor concept and the associated sub-systems will require evaluation in order to determine a path forward to a FOAK microreactor.

\subsection{Reactor Types}

Microreactors can generally be categorized by their fuel type, neutron spectrum, and heat removal method. In the U.S., two general microreactor types are currently being considered at the MW scale:

- High-Temperature Gas Reactors (HTGRs) using tristructural isotropic (TRISO) fuel and operating in a thermal neutron spectrum. These reactors are typically designed to use forced circulation of helium for the primary coolant through the core.

- Heat Pipe Reactors using metallic, oxide, or nitride fuel and operating in a fast neutron spectrum. These reactors typically use sodium $(\mathrm{Na})$, potassium $(\mathrm{K})$, or $\mathrm{NaK}$ heat pipes, which operate at high temperatures around the boiling point of the working fluid contained in the passive, selfpumping heat pipes.

Some reactor developers have historically considered pumped liquid-metal cooled, fast-spectrum reactors that use either sodium or lead coolant for MW-class systems. One European developer is currently considering a lead cooled fast reactor concept, but they have not expressed any interest in the U.S. market and presently there is no evident U.S. developer interest in this technology.

Based on an INL study, the DSB report summarized some generic performance attributes [2]. These attributes, shown in 
Table 3.1, cover a generic HTGR concept, the Los Alamos National Laboratory (LANL) heat pipe concept, and a smaller radioisotope power system for comparison. The HTGR and heat pipe concepts use nearly the same amount of U-235, although in different forms for each concept. One significant difference is the operating temperature, with the HTGR nearly $200{ }^{\circ} \mathrm{C}$ above that of the heat pipe reactor. This should lead to higher efficiency of the power conversion system of the HTGR relative to the heat pipe reactor. One issue which is common to both concepts is the availability of high-assay, low-enriched uranium (HALEU). HALEU is $<20 \% \mathrm{U}-235$, and there is currently no well-defined source for this fuel. Down-blending of existing high-enriched uranium supplies or a new enrichment capability will be required for making the fuel for these reactors. 
Table 3.1. Performance attributes of microreactor candidates [2]

\begin{tabular}{|c|c|c|}
\hline $\begin{array}{l}\text { Performance } \\
\text { Attributes }\end{array}$ & $\begin{array}{l}\text { High Temperature Gas- Cooled } \\
\text { Reactor }\end{array}$ & LANL Heat Pipe Reactor \\
\hline $\begin{array}{l}\text { Power output } \\
\left(\mathbf{M W}_{\mathrm{e}}\right)\end{array}$ & 5 & 2 \\
\hline $\begin{array}{l}\text { Shutdown cooling } \\
\left(\mathbf{M W}_{\mathrm{t}}\right)\end{array}$ & $<2$ (decay heat) & $<0.8$ \\
\hline $\begin{array}{l}\text { Operating temp } \\
\left({ }^{\circ} \mathrm{C}\right)\end{array}$ & 850 (outlet) & 675 (outlet) \\
\hline Fuel type (TRL) & UCO TRISO (TRL 5-6) & $\mathrm{UO}_{2}$ (TRL 9) \\
\hline $\begin{array}{l}\text { Fuel clad failure } \\
\text { temp. }\left({ }^{\circ} \mathrm{C}\right)\end{array}$ & $>1650$ & $\sim 1450$ \\
\hline $\begin{array}{l}\text { LOCA peak reactor } \\
\text { temp. }\left({ }^{\circ} \mathrm{C}\right)\end{array}$ & $\sim 1250$ & $\sim 1200$ \\
\hline Emergency cooling & Passive & Passive \\
\hline $\begin{array}{l}\text { Operating pressure } \\
\text { (MPa) }\end{array}$ & 7.4 & 0 \\
\hline $\begin{array}{l}\text { Fuel (fissile) } \\
\text { quantity }\end{array}$ & $\begin{array}{l}\sim 800 \mathrm{~kg} \mathrm{U}-235 \\
(<20 \% \text { enrichment })\end{array}$ & $\begin{array}{l}\sim 880 \mathrm{~kg} \mathrm{U}-235 \\
(19.75 \% \text { enrichment })\end{array}$ \\
\hline $\begin{array}{l}\text { Release potential if } \\
\text { breached }\end{array}$ & $\begin{array}{l}\text { TRISO should retain fission } \\
\text { products }\end{array}$ & $\begin{array}{l}\text { Minimal release (atm press; fuel in SS } \\
\text { block) }\end{array}$ \\
\hline $\begin{array}{l}\text { Cladding/encapsulat } \\
\text { ion }\end{array}$ & Silicon carbide & SS-316L \\
\hline $\begin{array}{l}\text { Refueling approach } \\
\text { and interval }\end{array}$ & $\begin{array}{l}\text { Refuel by replacement of reactor } \\
\text { fuel module every } 2 \text { yrs }\end{array}$ & $\begin{array}{l}\text { Refuel by replacement of reactor fuel } \\
\text { module every } 5 \text { yrs }\end{array}$ \\
\hline
\end{tabular}

\subsubsection{High-Temperature Gas-cooled Reactor}

HTGRs operate in a thermal neutron spectrum and typically circulate high-pressure helium gas to extract nuclear heat from the fuel. Helium coolant cannot become radioactive, thereby minimizing any risks associated with a loss of the primary coolant. The use of graphite blocks and TRISO particle fuel with the ability to retain fission products within the multi-layer spherical particles also reduces the risk of radioactivity release to the environment [2]. HTGRs also have strong negative temperature reactivity feedback from the graphite moderator and fuel. By design, these reactors are inherently safe to operate and have reduced probability of a core meltdown [30]. 
Most of the proposed concepts cycle the primary coolant through a heat exchanger to a secondary circuit, which in turn cycles through a generator (or other process). An alternative concept from HolosGen is derived from a nuclear turbojet concept initially proposed by General Electric (GE) in the 1960s [31]. The HolosGen concept in Figure 3.1 is a compact, closed loop, combined nuclear-turbine which heats helium or $\mathrm{CO}_{2}$ in a reactor before passing it immediately through a turbine [32].
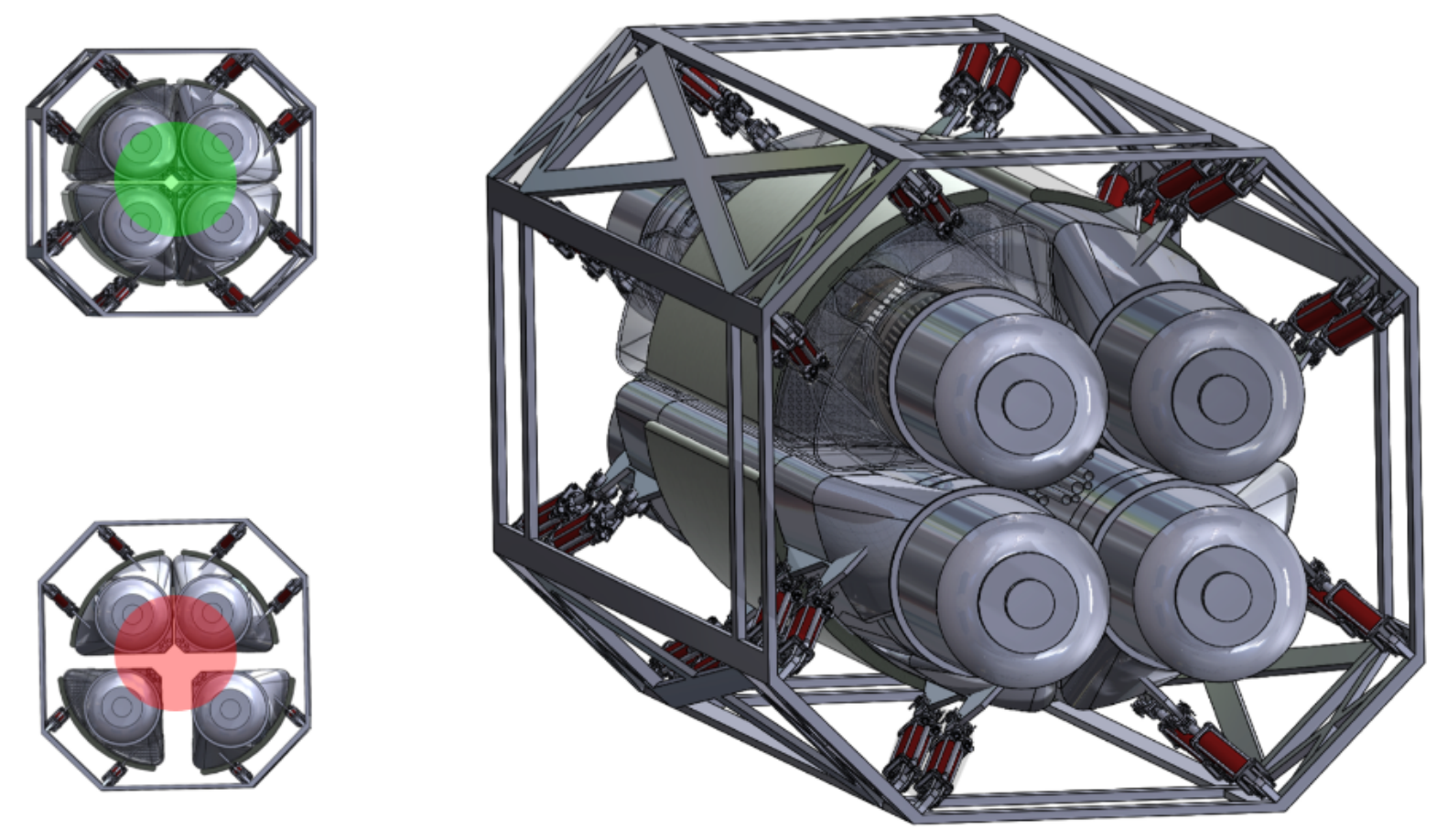

Figure 3.1. HolosQuad reactor [33].

In considering HTGRs for micro-reactor applications, several important factors stand out:

- Packing fraction of the TRISO particles: The current limit for TRISO packing fraction is approximately $40 \%$ before the particles begin to experience damage during compacting.

- Reactor shielding: Potentially several feet of steel shielding will be necessary outside of the container housing the reactor.

Refueling: From 
- Table 3.1, fuel modules would be replaced approximately every 2 years, which is significantly more frequent than the 5 year cycle anticipated for a heat pipe reactor.

- End of life disposition: While the fuel can be easily removed from the reactor and stored safely, the non-nuclear components will also need to be disposed.

- Manufacturing of graphite blocks: The reactor core structure housing the TRISO fuel is likely to be made of graphite blocks. Methods for manufacturing nuclear grade graphite will need to be defined.

\subsubsection{Heat Pipe Cooled Reactor}

Researchers at LANL and the U.S. National Aeronautics and Space Administration (NASA) have a long history of investigating the use of liquid-metal heat pipes for primary reactor cooling for tens to hundreds of kilowatt scale NASA missions (including use for both power and electric propulsion) [34]. Recently, scaled-up versions which operate at the 5-10 MWe level have been investigated by the national laboratories [1], [35]. These reactors maintain a core structure interspersed with fuel and heat pipes which extend outside the core. The heat pipes typically operate with sodium, potassium, or NaK working fluid at low pressure. Additionally, the heat pipes are passive devices, negating the need for external pumping of coolant. One concept which is being pursued by Westinghouse is the eVinci reactor in Figure 3.2.

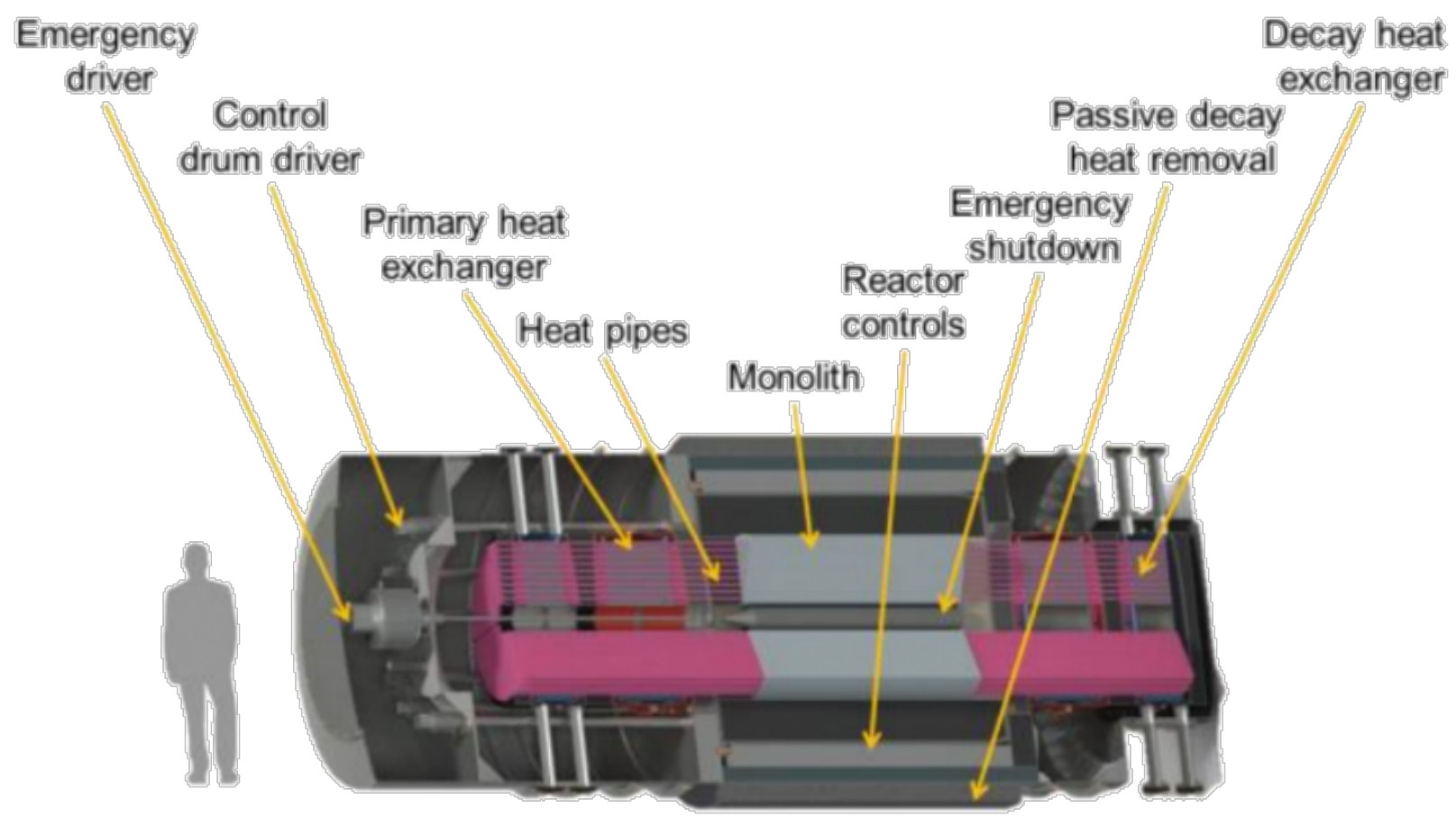

Figure 3.2. Westinghouse eVinci heat pipe cooled reactor concept [36].

Heat pipe reactors tend to operate around the boiling point of the heat pipe working fluid. For potassium heat pipes, the operating temperature is approximately $760^{\circ} \mathrm{C}$. For sodium, ${ }^{\mathrm{c}}$ the operating temperature is approximately $880^{\circ} \mathrm{C}$. Depending on how the reactor is designed, these high temperatures

\footnotetext{
${ }^{c}$ Sodium heat pipe reactors are occasionally referred to as Sodium Fast Reactors (SFRs). This is a bit of a misnomer. Traditionally, SFRs are sodium-cooled reactors with pumps cycling a large quantity of sodium through the core. Sodium heat pipe reactors operate passively, using the phase change of sodium to transfer heat from the core. Since sodium heat pipe reactors operate around the boiling temperature of sodium, they are operating at higher temperatures than traditional SFRs. Sodium heat pipe reactors also use a much smaller mass of sodium than SFRs. Both reactor types operate in the fast spectrum.
} 
present potential obstacles, particularly in selection of structural and pressure boundary materials for components in the reactor core. Each proposed heat pipe reactor concept will need to be evaluated to determine the applicable engineering standards and whether the desired structural materials are approved for use at the expected operating temperatures. If new materials are proposed, the viability of building a code-case to qualify a material will need to be considered, since the qualification process can be potentially long and costly.

Some considerations when evaluating heat pipe reactors include:

- Fuel source and manufacturing: Different microreactor concepts may have different fuel forms in both shape and composition. Two INL concepts considered both cylindrical fuel pins and hexagonal elements [35]. Given the number of fuel pins/elements in a heat pipe reactor, reliable manufacturing processes for both the fuel and the cladding will be critical.

- Refueling: In the LANL MegaPower design, both the fuel and heat pipes are housed, un-cladded, inside channels of a stainless steel monolith [1]. This potentially complicates refueling of the reactor.

- End of Life Disposition: Similar to the HTGR concepts, methods for disassembly and disposal of the fueled and unfueled components of the reactor need to be defined.

- Manufacturing of the monolith core: The LANL MegaPower design calls for a stainless steel monolith to house the heat pipes and fuel. In a 2017 Phenomena Identification and Ranking Table (PIRT) analysis of the MegaPower concept by INL, the manufacturability of the steel monolith was identified as a significant issue [37]. Hot isostatic press (HIP), 3D printing or other advanced manufacturing processes may yield a path forward on monolith manufacturability.

\subsubsection{Lead Fast Reactor}

Lead Fast Reactors (LFRs) operate in a fast neutron spectrum and circulate molten lead as the primary coolant. The reactor coolant is nominally at low pressure and has a high boiling point. This allows for higher temperature operation, providing higher efficiency in the power conversion system, and eliminating boiling concerns [38].

Presently, LFRs are being pursued primarily outside the U.S. for research reactor applications and limited power applications. The current designs do not appear easily transportable.

\subsubsection{Others}

Sodium Fast Reactors (SFRs) are fast spectrum reactors with molten sodium coolant. These reactors use an intermediate heat exchanger (IHX) to transfer heat from the molten sodium to water, which is used in a steam turbine system for electrical power generation [39]. Presently, SFRs at the size and power scale of interest for microreactor applications are not being pursued in the U.S.

\subsection{Thermal Transport \& Heat Exchangers}

In order for the thermal energy generated in a nuclear reaction to be useful, it must be transferred out of the reactor to the power conversion system or heat exchanger for process heat end use. Additionally, in order to regulate the fuel temperature during both normal operation and after shutdown, the primary thermal transport system must be able to adequately transfer heat to the environment. Given the small size of microreactors, ambient air can be used as the ultimate heat sink in electricity generating cases. For process heat applications such as desalination, another fluid, such as sea water, may be the ultimate heat sink.

\subsubsection{Heat Pipes and Thermosiphons}

One option for removing heat from the reactor core is by using heat pipes. Heat pipes are passive devices, requiring no pumps to circulate a coolant. Rather, the coolant circulates within a heat pipe 
through the evaporation and condensation cycle of a working fluid as illustrated in Figure 3.3. In the reactor core section, heat conducts from the fuel to the heat pipe. Inside the heat pipe, the working fluid is evaporated and the vapor transports to the other end of the pipe. At the condenser end of the pipe, external cooling removes heat and causes the working fluid to condense. The fluid condenses into the wick structure, and moves by capillary motion back to the evaporator end of the pipe. A thermosiphon is similar to a heat pipe, but does not contain a wick. This limits the energy transfer capacity of a thermosiphon relative to a heat pipe.

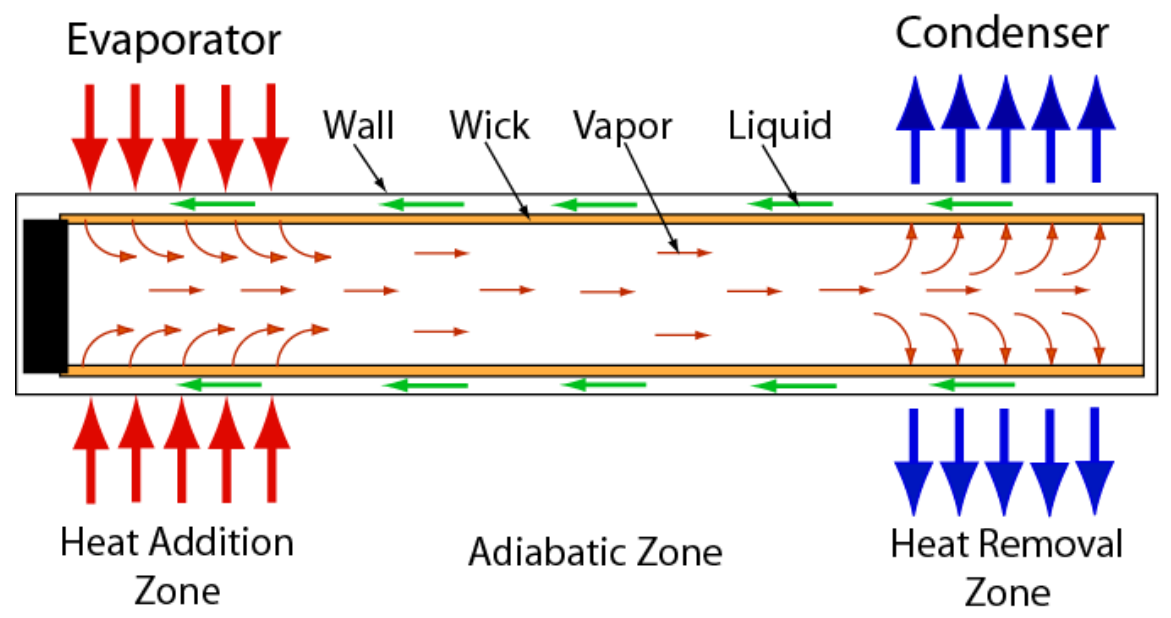

Figure 3.3. Heat pipe operation schematic [40]

Heat pipes have been used extensively in small reactors, such as kilowatt space reactors. Because they operate passively and require few components, they are extremely reliable. They also allow operation at higher temperatures, thereby increasing the efficiency of the power conversion system. Heat pipe operating temperature is essentially determined by the boiling temperature of the working fluid. Table 3.2 shows the boiling temperatures of a few candidate working fluids for microreactor heat pipes.

Table 3.2. Boiling temperature of selected heat pipe working fluids

\begin{tabular}{|l|l|}
\hline Working Fluid & Boiling Temperature \\
\hline Potassium $(\mathrm{K})$ & $759^{\circ} \mathrm{C}$ \\
\hline NaK & $785^{\circ} \mathrm{C}$ \\
\hline Sodium $(\mathrm{Na})$ & $883^{\circ} \mathrm{C}$ \\
\hline
\end{tabular}

\subsubsection{Intermediate Heat Exchangers}

Most microreactor designs utilize an IHX to transfer heat from the primary reactor coolant to the secondary coolant which interfaces with the power conversion system. This design is typical in nuclear power and has the benefit of keeping the nuclear heated primary coolant separate from the secondary coolant that passes through the power conversion system.

The supercritical carbon dioxide $\left(\mathrm{sCO}_{2}\right)$ recompression Brayton cycle is a cycle developed at the Massachusetts Institute of Technology [41]. The $\mathrm{sCO}_{2}$ coolant is heated by the available heat from the heat pipe reactor and further expanded through the turbine to produce electric power. Using $\mathrm{sCO}_{2}$ as the power cycle working fluid enables one to achieve much higher thermal efficiencies $(\sim 45 \%$ and above for recompression cycle at $550^{\circ} \mathrm{C}$ ) and compact turbomachinery (with few components), which could be modularly constructed and has a much smaller footprint [42]. The existing challenges with $\mathrm{SCO}_{2}$ are the high turbine inlet pressure and that the cycle is still in small-scale testing, and therefore not available commercially. 
The calculated power conversion cycle thermal efficiency ( $\eta$ pcs) could be defined as:

$$
\eta_{\text {pcs }}=\left(P_{\text {turbine }}-P_{\text {compressors }}\right) / P_{\text {reactor }}
$$

where:

$\mathrm{P}_{\text {turbine }}=$ Power of the primary side

$\mathrm{P}_{\text {compressors }}=$ Power of the high and low pressure compressors

$\mathrm{P}_{\text {reactor }}=$ Reactor heat

The type of power conversion system has not yet been finalized. Once the type of power conversion system is decided, the assumptions, performance and requirements will be narrowed down.

Table 3.3 summarizes general operating conditions and principal features for various heat exchanger types in the current industry [43]. This table summarizes the following:

- Heat exchanger type: Fifteen heat exchanger types are listed in this table.

- Compactness: Indicates (surface area)/ (heat exchanger core volume). If compactness is high, the heat exchanger can be smaller.

- System Type: Indicates what fluid phases are generally used for a certain heat exchanger type in the industry.

- Material: Indicates materials which have been used for specific heat exchangers in current industry.

- Temperature Range: Indicates the applicable temperature ranges of a certain type of heat exchanger.

- Maximum Pressure: Indicates the applicable pressure ranges of a certain type of heat exchanger.

- Cleaning Method: Indicates if the heat exchanger can be cleaned physically or chemically.

- Multistream Capability: Indicates if it can connect several independent flow loops in a single heat exchanger.

- Multipass Capability: Indicates if it can split flow into several paths in the heat exchanger. 
Table 3.3. Principal features of several types of heat exchangers [43].

\begin{tabular}{|c|c|c|c|c|c|c|c|c|}
\hline $\begin{array}{c}\text { Heat Exchanger } \\
\text { Type }\end{array}$ & $\begin{array}{c}\text { Compactness } \\
\left(\mathrm{m}^{2} / \mathrm{m}^{3}\right)\end{array}$ & System Types & Material & $\begin{array}{c}\text { Temperature } \\
\text { Range } \\
(C)^{\mathrm{a}}\end{array}$ & $\begin{array}{c}\text { Maximum } \\
\text { Pressure } \\
\text { (bar) }^{\mathbf{b}}\end{array}$ & $\begin{array}{c}\text { Cleaning } \\
\text { Method }\end{array}$ & $\begin{array}{c}\text { Multistream } \\
\text { Capability } \\
\end{array}$ & $\begin{array}{c}\text { Multipass } \\
\text { Capabilityd } \\
\end{array}$ \\
\hline Shell and Tube & $\sim 100$ & $\begin{array}{l}\text { Liquid/Liquid, Gas/Liquid, } \\
\text { 2Phase }\end{array}$ & $\begin{array}{l}\text { s/s, Ti, Incoloy, Hastelloy, } \\
\text { graphite, polymer }\end{array}$ & $\sim+900$ & $\sim 300$ & $\begin{array}{l}\text { Mechanical, } \\
\text { Chemical }\end{array}$ & No & Yes \\
\hline $\begin{array}{l}\text { Plate-and-frame } \\
\text { (gaskets) }\end{array}$ & $\sim 200$ & $\begin{array}{l}\text { Liquid/Liquid, Gas/Liquid, } \\
\text { 2Phase }\end{array}$ & $\begin{array}{l}\text { s/s, Ti, Incoloy, Hastelloy, } \\
\text { graphite, polymer }\end{array}$ & $-35 \sim+200$ & 25 & Mechanical & Yes & Yes \\
\hline $\begin{array}{l}\text { Partially welded } \\
\text { plate }\end{array}$ & $\sim 200$ & $\begin{array}{l}\text { Liquid/Liquid, Gas/Liquid, } \\
\text { 2Phase }\end{array}$ & s/s, Ti, Incoloy, Hastelloy & $-35 \sim+200$ & 25 & $\begin{array}{l}\text { Mechanical, } \\
\text { Chemical }\end{array}$ & No & Yes \\
\hline $\begin{array}{l}\text { Fully welded plate } \\
\text { (Alfa Rex) }\end{array}$ & $\sim 200$ & $\begin{array}{l}\text { Liquid/Liquid, Gas/Liquid, } \\
\text { 2Phase }\end{array}$ & s/s, Ti, Ni alloys & $-50 \sim+350$ & 40 & Chemical & No & Yes \\
\hline Brazed plate & $\sim 200$ & Liquid/Liquid, 2Phase & $\mathrm{s} / \mathrm{s}$ & $-195 \sim+220$ & 30 & Chemical & No & No \\
\hline Bavex plate & 200 to 300 & Gas/Gas, Liquid/Liquid, 2Phase & s/s, Ni, Cu, Ti, special steels & $-200 \sim+900$ & 60 & $\begin{array}{l}\text { Mechanical, } \\
\text { Chemical }\end{array}$ & Yes & Yes \\
\hline Platular plate & 200 & Gas/Gas, Liquid/Liquid, 2Phase & s/s, Hastelloy, Ni alloys & $\sim 700$ & 40 & Mechanical & Yes & Yes \\
\hline Compabloc plate & $\sim 300$ & Liquid/Liquid & s/s, Ti, Incoloy & $\sim 300$ & 32 & Mechanical & Not usually & Yes \\
\hline Packinox plate & $\sim 300$ & Gas/Gas, Liquid/Liquid, 2Phase & s/s, Ti, Hastelloy, Inconel & $-200 \sim+700$ & 300 & Mechanical & Yes & Yes \\
\hline Spiral & $\sim 200$ & Liquid/Liquid, 2Phase & s/s, Ti, Incoloy, Hastelloy & $\sim 400$ & 25 & Mechanical & No & No \\
\hline Brazed plate fin & 800 to 1500 & Gas/Gas, Liquid/Liquid, 2Phase & $\mathrm{Al}, \mathrm{s} / \mathrm{s}, \mathrm{Ni}$ alloy & $\sim 650$ & 90 & Chemical & Yes & Yes \\
\hline $\begin{array}{l}\text { Diffusion bonded } \\
\text { plate fin }\end{array}$ & 700 to 800 & Gas/Gas, Liquid/Liquid, 2Phase & $\mathrm{Ti}, \mathrm{s} / \mathrm{s}$ & $\sim 500$ & $>200$ & Chemical & Yes & Yes \\
\hline Printed circuit & 200 to 5000 & Gas/Gas, Liquid/Liquid, 2Phase & $\mathrm{Ti}, \mathrm{s} / \mathrm{s}$ & $-200 \sim+900$ & $>400$ & Chemical & Yes & Yes \\
\hline $\begin{array}{l}\text { Polymer (e.g. } \\
\text { channel plate) }\end{array}$ & 450 & Gas/Liquid & PVDF, PP & $\sim 150$ & 6 & Water Wash & No & No \\
\hline Plate and shell & - & Liquid/Liquid & $\mathrm{s} / \mathrm{s}, \mathrm{Ti}$ & $\sim 350$ & 70 & $\begin{array}{l}\text { Mechanical, } \\
\text { Chemical }\end{array}$ & Yes & Yes \\
\hline \multicolumn{9}{|c|}{$\begin{array}{l}\text { s/s } \\
\text { a. Heat exchanger operational temperature ranges. } \\
\text { b. Heat exchanger maximum applicable pressure. } \\
\text { c. Capability to connect several independent flow loops in a single heat exchanger. } \\
\text { d. Capability to split flow into several paths in the heat exchanger. }\end{array}$} \\
\hline
\end{tabular}




\subsection{Power Conversion System}

An integral part in designing a Special Purpose reactor is its power conversion unit (PCU). For military ground operations, the efficiency of the PCU may not be as important as its size and portability. However, for isolated communities where economics is important, the thermal efficiency may have a higher value.

Developing power conversion units that best fit the reactor type is an important part of the reactor development process. A wide variety of power conversion units should be considered. A study at Idaho National Laboratory with respect to small modular reactors showed that the reactor inlet and outlet temperatures had an effect on the performance of a wide variety of power conversion units [44].

\subsubsection{Rankine Steam Cycle}

The Rankine cycle is the most common power conversion cycle used in the nuclear power industry. Figure 3.4 illustrates a simplified flow diagram for the model used for the Rankine power cycle. The Rankine cycle is typically comprised of high, intermediate, and low-pressure turbines. High-pressure steam is generated by a heat source, such as a nuclear reactor, and then passed through a turbine or set of turbines to generate power. The low-pressure steam/water effluent mixture is condensed and then is pumped back to high pressure before entering the steam generator. To increase the efficiency of the cycle, after the first turbine expansion, the power cycle steam is reheated by the heat source to the same temperature as the steam entering the high-pressure turbine [45].

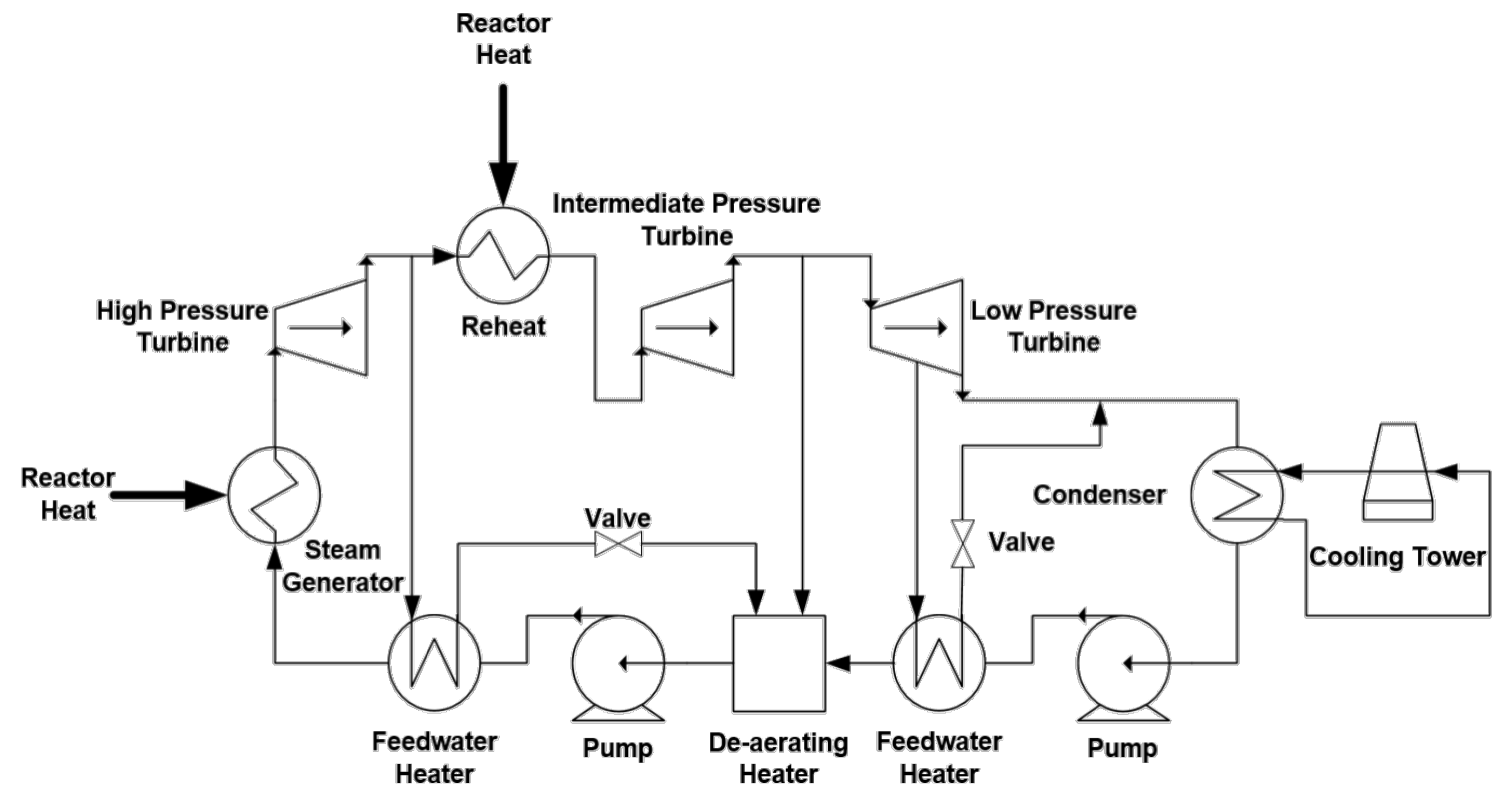

Figure 3.4. Rankine cycle with feed-water heaters and reheat.

Another means to increase the efficiency of the cycle is to add feed-water heaters. Feed-water heaters are recuperating heat exchangers that draw steam from turbines to heat the feed-water that is returning from the condenser to the steam generator, which reduces the amount of heat needed by the steam generator to generate the same power. By balancing the amount of steam and the pressure at which the steam is drawn, the cycle can be optimized for maximum thermal efficiency. The high pressure within the power cycle steam loop is set by the temperature exiting the steam generator and the amount of superheating needed for the system. The low pressure of the system is determined by the condensing temperature, which is a function of the temperature of the cooling water used to cool the condenser. For special purpose reactors, a single turbine should be sufficient. A feed-water heater and reheat could still 
be applied. With respect to reactor outlet temperatures, the steam Rankine cycle can provide ideal thermal efficiencies, electric power to heat input ratio, up to temperatures of $600^{\circ} \mathrm{C}$ [44]. The cycle has decades of development and operational experience.

\subsubsection{Closed Brayton Gas Cycle}

A closed Brayton gas cycle is shown in Figure 3.5. In this cycle, the hot, high-pressure working gas is expanded in a turbine to produce power. The low-pressure warm gas is further cooled through heat recuperation with the return gas from the compressors. A gas cooler rejects heat to the cooling tower before compression within the low-pressure compressor. The heat generated by the compressor is rejected by an intercooler to a cooling tower or ambient fluid. The gas is further compressed by the high-pressure compressor before entering the recuperating heat exchanger. Finally, heat is added to the gas at the gas heater.

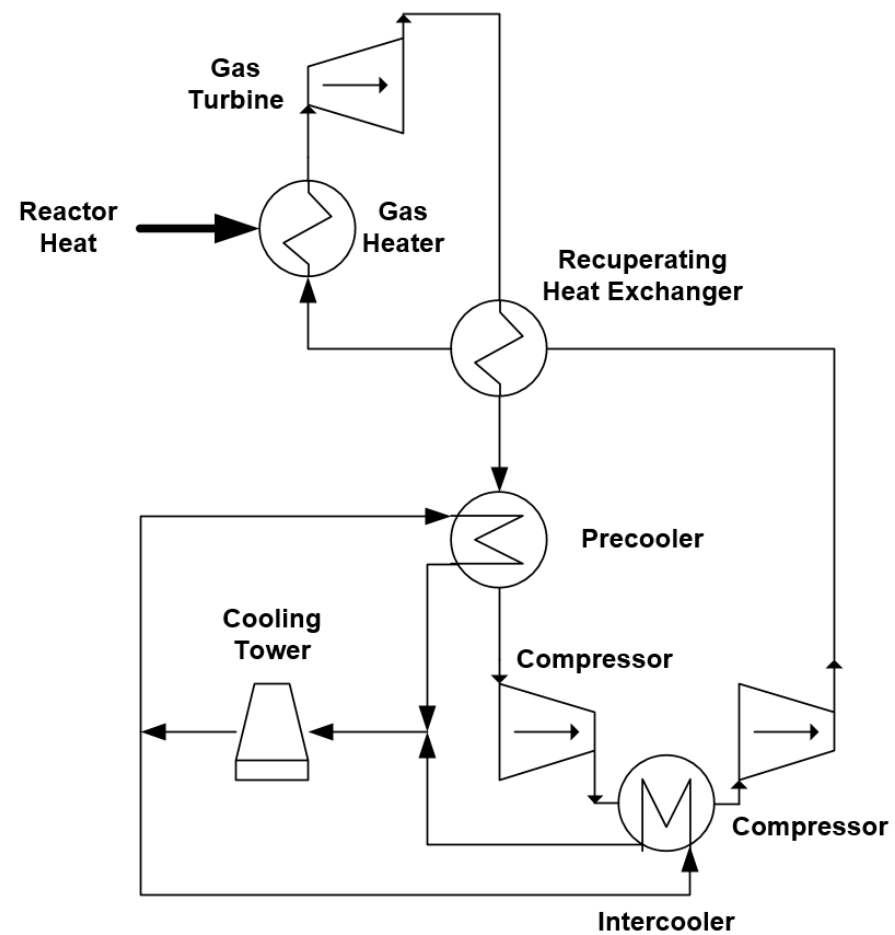

Figure 3.5. Closed Brayton cycle with recuperation and intercooling.

The dual compression with cooling reduces the work of compression, which helps in providing a more efficient cycle. Recuperation reduces the amount of heating needed at the gas heater and the amount of heat rejection at the gas cooler and intercooler, which helps attain higher thermal efficiencies. The pressure ratio across the turbine has a greater effect on thermal efficiency than a given high or low pressure. The Brayton cycle can run at a variety of pressures. For a given low pressure, the high pressure is set by the optimal pressure ratio or a given high pressure ratio. Higher pressures produce high densities throughout the cycle, which in turn could reduce equipment size. However, operation at higher temperature and pressure would require more expensive materials when compared to lower pressure cycles. By the same logic, low pressure systems would require large equipment sizes to account for the larger volumetric flows.

The closed Brayton cycle could be used as the primary loop for a high temperature gas reactor. Power output would be at its greatest for a given reactor outlet temperature, and by generating power, the working fluid is at a much lower temperature during compression, thereby reducing compression costs when compared to a primary loop circulator. For special purpose reactors, having the cycle as the primary 
coolant loop would reduce the footprint considerably. The disadvantage is the contamination of the power conversion unit. The Brayton cycle alone, however, is not effective at lower reactor temperatures $<500^{\circ} \mathrm{C}$ but improves at higher temperatures.

\subsubsection{Open Air Brayton Cycle}

The open air Brayton cycle shown in Figure 3.6 is a common cycle used in power production and jet aircraft. For power production using only the open air Brayton cycle, recuperation is critical to increase the thermal efficiency of the cycle.

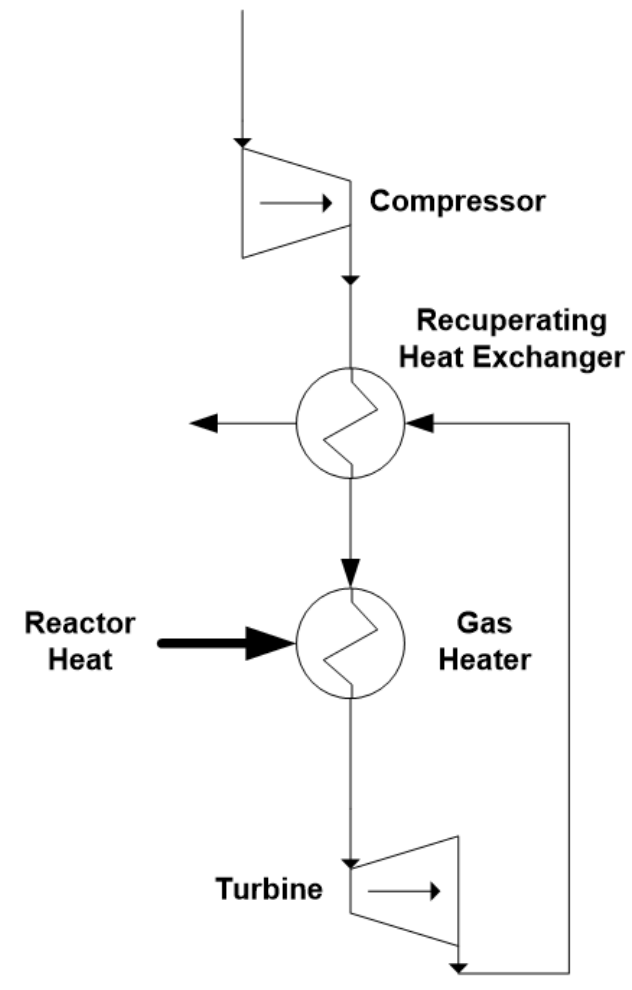

Figure 3.6. Open air Brayton cycle with recuperation.

Ambient air is first compressed to a higher pressure before entering the recuperating heat exchanger. The air is then pre-heated in the recuperating heat exchanger by the hot air returning from the turbine. Heat is added to the air at the heater before the air is expanded through a turbine. Power is generated at the turbine as the air is expanded. The air is further cooled within the recuperating heat exchanger before it is rejected to the atmosphere. The heat rejected by the power cycle is carried by the exiting air.

The low pressure within an open air Brayton cycle is the pressure of the ambient air. The high pressure is set by the optimal thermal performance of the cycle. Air Brayton cycles have small footprints and the least amount of equipment. They also have a long legacy of development and a high technology readiness level. However, they tend to have the lowest thermal efficiencies when considering only the cycle itself.

The INL PIRT analysis conducted for the LANL MegaPower reactor examined the power conversion system in some detail [37]. The report examined an air Brayton cycle due to its wide use in power conversion systems, and therefore the wide availability of components. Depending on factors such as supply temperature and heat-recuperation, thermal efficiencies were calculated to be between $25 \%$ and $40 \%$. The analysis also determined that commercial units are available to meet the design requirements. 


\subsubsection{Supercritical Carbon Dioxide Recompression Brayton Cycle}

A process diagram for the supercritical carbon dioxide recompression Brayton cycle, $\mathrm{sCO}_{2}$, is provided in Figure 3.7. High pressure ( $\sim 20 \mathrm{MPa})$ supercritical $\mathrm{CO}_{2}$ is heated to a high temperature by the gas heater. Power is produced by expanding the gas through the turbine. The low-pressure gas is cooled to a lower temperature within the high temperature recuperating heat exchanger or recuperator (HTR) by the gas returning from the compressors. The gas is further cooled within the low temperature recuperator (LTR) by the gas returning from the main compressor. The gas flow exiting the LTR is split into two unequal streams. The larger fraction of the flow is cooled by the cooling tower before compression at the main compressor. The smaller fraction of the flow is directly compressed without cooling at the recompression compressor. The heat from the recompression compressor is used to raise the temperature of the exiting gas. This higher temperature gas reduces the amount of heat needed at the gas heater for a given power output.

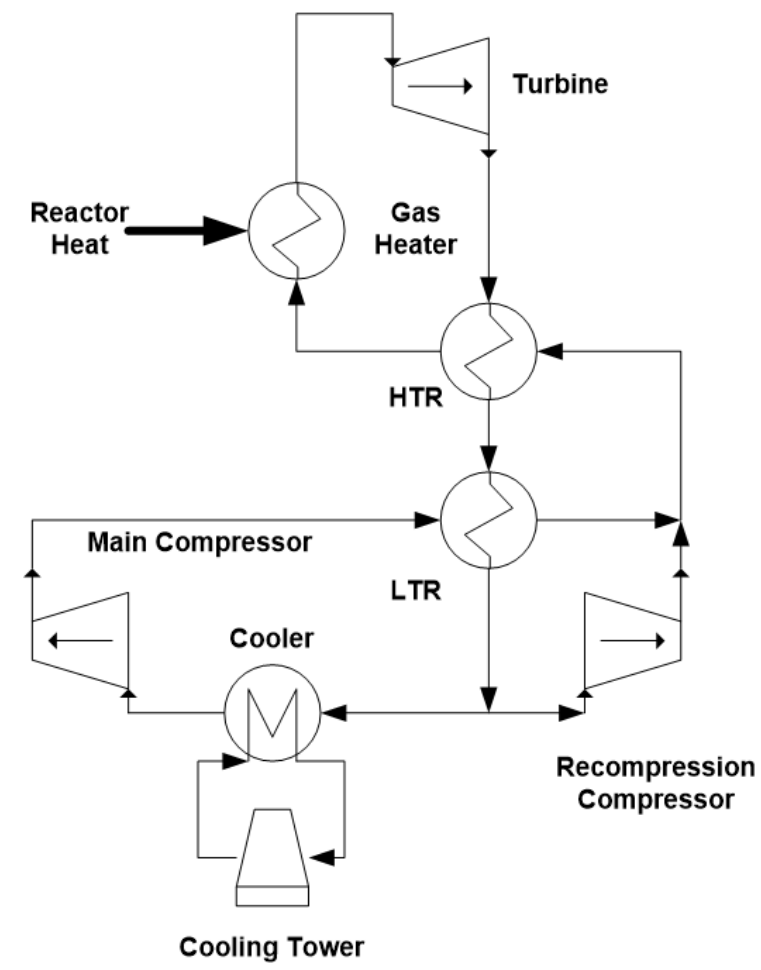

Figure 3.7. Supercritical carbon dioxide recompression Brayton cycle.

The optimal thermal efficiency is achieved by balancing the flow between the main compressor and the recompression compressor. If too much flow goes to the recompression compressor, the power to run the compressor will reduce the thermal efficiency of the cycle. The biggest advantage of the cycle is the high density of the $\mathrm{CO}_{2}$ at the compression stages. The pressure at this point is just above the critical point of $\mathrm{CO}_{2}(\sim 7.3 \mathrm{MPa})$. The high density of the $\mathrm{CO}_{2}$ reduces the work of compression. Due to the high pressures within the cycle, the footprint for this cycle is small. However, the cycle is under development and does not have the legacy of operation that the air Brayton and steam Rankine cycles have.

\subsubsection{Organic Rankine Cycle}

An Organic Rankine cycle (ORC) is a Rankine cycle which uses a refrigerant instead of steam as the working fluid. The cycle works well with low temperature heat and has the following advantages:

- Evaporation occurs at lower pressures and temperatures

- The condensation pressure is above atmospheric which prevents air intake 
- Single stage turbines may be used due to smaller temperature differences between the evaporator and the condenser.

Recent scoping studies by INL and the University of Idaho have shown that for a micro reactor with an outlet temperature of $675^{\circ} \mathrm{C}$ (e.g. heat pipe or molten salt reactor), the thermal efficiency can increase from $35 \%$ to $40 \%$ with the addition of an ORC to a recuperated air Brayton cycle.

\subsubsection{Other Power Conversion Units}

Most power conversion units use a simple compressible system in some form or other to provide the power. The previously described PCUs are these type of systems. Other PCUs of this type are Stirling and Ericsson cycles. The Stirling cycle uses a gas, such as air, as a working fluid. Heat is transferred to the cycle during a constant volume process and during isothermal expansion. Heat is rejected during a constant volume and isothermal compression. The Ericsson cycle uses constant pressure processes in place of the constant volume processes of the Stirling cycle. Both use a regenerator which allows the cycles to have potential high efficiencies.

Systems other than simple compressible systems can also provide power. As a potential source of supplemental power to support emergency operations, thermoelectric modules could be added to the reactor. These modules work by using the electric potential generated in a thermoelectric material from a temperature differential. They are highly inefficient but could be useful for providing some small amount of reliable power for ensuring operation of critical equipment. 


\section{MICROGRID INTEGRATION}

The main purpose of microgrids is to provide the means for integration of distributed generation sources into electricity grids and to allow those sources to operate independently in a reliable, secure, and controlled manner. One of the most important characteristics of microgrids is that the distributed power sources are in close proximity to the end users [46]. A smart microgrid will further allow for power and data to flow both ways between the supply and demand ends of the grid, enabling demand response functionality [47]. The communication infrastructure, known as "Advanced Metering Infrastructure," uses smart meters to enable two-way interaction, such that demand and supply are linked and are able to manage peak demands by sending signals to the customers. This in turn allows customers to reduce consumption in response to those signals [47]. Current grids are not considered "smart" mainly because the consumers are not involved and are not given choices or tools to help them manage and control their usage, especially during system peak demand hours or during supply shortages [48].

The motivations for introduction of a microgrid include the following:

- Communities or regions which are too isolated or remote to connect to the main electrical grid.

- Microgrids which can connect to and disconnect from the main grid, as necessary, can have an economic advantage when coupled with modern controls to account for fluctuations in supply and demand. This leads to less wasted energy and greater cost savings [49].

- Microgrids expedite the integration of renewable energy sources, such as solar and wind. The intermittent nature of renewable energy results in variable generation when integrated into the main grid. These variations are easier to predict in microgrids, and could be supplemented by microreactors.

- Since microgrids operate independent of the main grid, they are not impacted by outages in the main grid. There are also fewer voltage sags and frequency interruptions in microgrids [50].

There are currently several operating microgrids. Table 4.1 provides some examples of operating microgrids, including their generating capacity and the technologies they utilize. 
Table 4.1. Examples of microgrids [51], [52]

\begin{tabular}{|c|c|c|c|}
\hline Location & Purpose(s) & $\begin{array}{c}\text { Total Generating } \\
\text { Capacity }\end{array}$ & $\begin{array}{c}\text { Energy Generation } \\
\text { Sources }\end{array}$ \\
\hline Bornholm Island, Denmark & $\begin{array}{l}\text { - Integrate renewable } \\
\text { energy into the grid } \\
\text { - Provide a microgrid test } \\
\text { bed }\end{array}$ & $127 \mathrm{MW}$ & $\begin{array}{l}\text { - Diesel generators } \\
\text { - Oil fired boiler } \\
\text { - Coal boiler } \\
\text { - } 35 \text { wind turbines } \\
\text { - Biogas turbines } \\
\end{array}$ \\
\hline $\begin{array}{l}\text { Hartley Bay, Northern } \\
\text { British Columbia, Canada }\end{array}$ & $\begin{array}{l}\text { Provide power to } \\
\text { commercial and } \\
\text { residential buildings in } \\
\text { a remote town }\end{array}$ & $1050 \mathrm{~kW}$ & - Diesel generators \\
\hline $\begin{array}{l}\text { Illinois Institute of } \\
\text { Technology }\end{array}$ & - Prevent power outages & $9 \mathrm{MW}$ & $\begin{array}{l}\text { - Combined cycle gas } \\
\text { - Small wind turbine } \\
\text { - Rooftop solar PV }\end{array}$ \\
\hline Fort Collins, Colorado & $\begin{array}{l}\text { - Increase grid efficiency } \\
\text { - Integrate renewable } \\
\text { energy into the grid } \\
\text { - Reduce peak loading }\end{array}$ & $3.5 \mathrm{MW}$ & $\begin{array}{l}\text { - Solar PV } \\
\text { - Fuel cells } \\
\text { - Biogas } \\
\text { - Diesel } \\
\end{array}$ \\
\hline Isle of Eigg & $\begin{array}{l}\text { - Integrate renewable } \\
\text { energy into the grid } \\
\text { - Reduce individual } \\
\text { generator use }\end{array}$ & $166 \mathrm{~kW}$ & $\begin{array}{l}\text { - Hydro-electric } \\
\text { - Solar PV } \\
\text { - Wind } \\
\text { - Diesel (individual } \\
\text { homes) }\end{array}$ \\
\hline Santa Rita Jail & $\begin{array}{l}\text { - Reduce energy } \\
\text { consumption from grid }\end{array}$ & $3.5 \mathrm{MW}$ & $\begin{array}{l}\text { - Solar PV } \\
\text { - Fuel cell } \\
\text { - Diesel (backup) }\end{array}$ \\
\hline $\begin{array}{l}\text { University of California at } \\
\text { San Diego }\end{array}$ & $\begin{array}{l}\text { - Reduce costs } \\
\text { - Increase resiliency }\end{array}$ & $31.2 \mathrm{MW}$ & $\begin{array}{l}\text { - Solar PV } \\
\text { - Gas turbine }\end{array}$ \\
\hline $\begin{array}{l}\text { University of Alaska- } \\
\text { Fairbanks }\end{array}$ & $\begin{array}{l}\text { - Power generation } \\
\text { - District heating }\end{array}$ & $17 \mathrm{MW}$ & - Coal \\
\hline
\end{tabular}

Power generation sources vary depending on the purpose of the microgrid and regional resource availability. Microgrids that are designed for increasing utilization of renewable energy do not prioritize diesel; however, in remote locations such as northern Canada where reliability is important, diesel is a good choice to assure power availability and reliability. Similarly, military bases are more concerned with reliability over efficiency and cost, and therefore tend to opt for diesel generators over variable renewable generators [53]. SMRs, which tend to range from 50-300 MWe, have been proposed as an option for microgrids. While offering reliability, SMRs tend to be more expensive and less flexible than other generation methods currently adopted within microgrids [54]. Figure 4.1 summarizes the use cases for different generation methods. Combining microgrids with microreactors offers significant flexibility which can support a wide range of applications. 


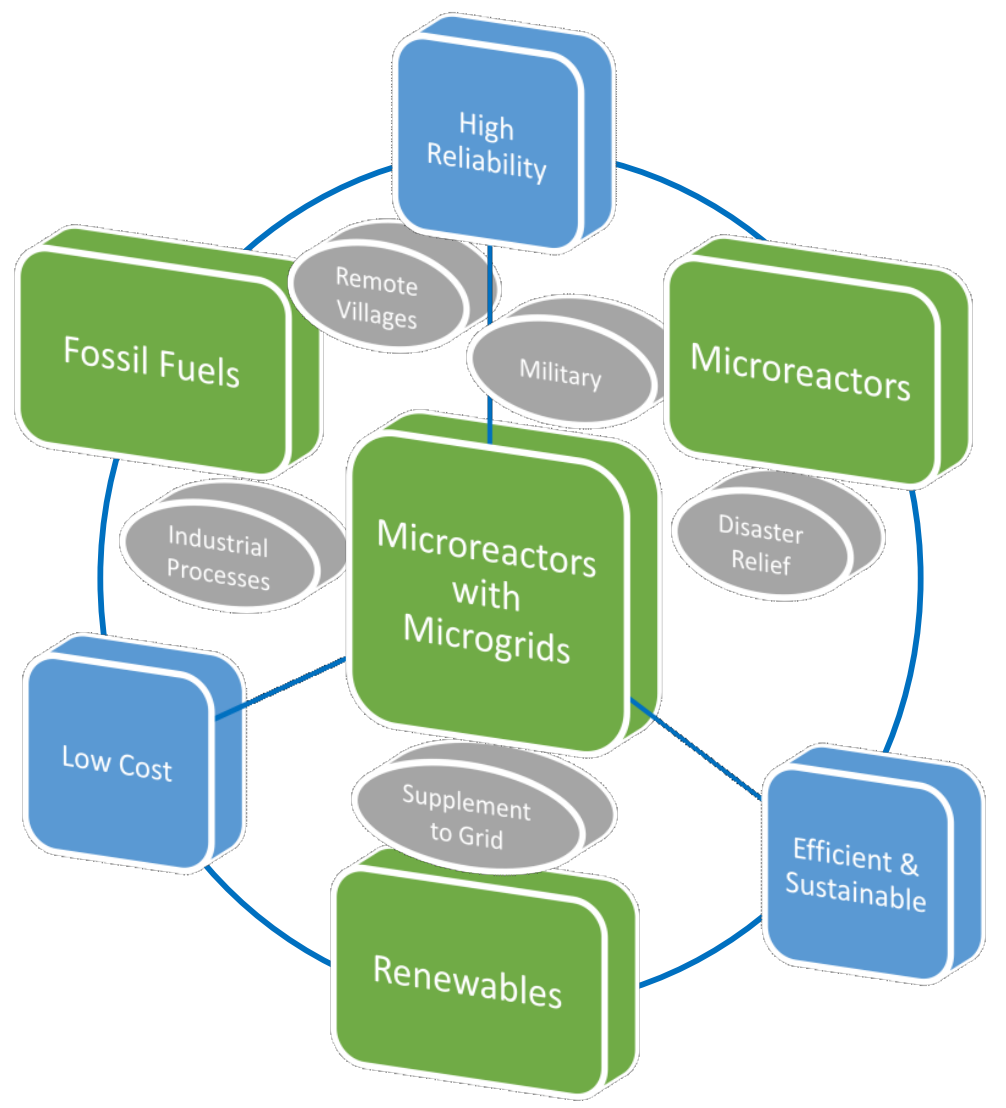

Figure 4.1. Energy generation methods, use cases, and benefits.

Due to their small size and increasing reliance on renewable energy sources, microgrids must be flexible. This results in a need for load-following capabilities and other ancillary services, such as voltage support and frequency control. When connected to a large grid, microgrids can load-follow by either taking energy from the main grid when more power is needed, or injecting power back into the main grid when the microgrid is producing a surplus. When microgrids are separated from the main grid and operating in "island mode," all load-following must be handled internally. This can be accomplished through the use of dispatchable generation from sources such as diesel or natural gas, energy storage (e.g., mechanical, thermal, electrical, or chemical), or variation in how energy is apportioned between heat applications and power generation. On short time scales of seconds or less, ancillary voltage support or frequency control services can balance momentary mismatches in supply and demand. Load-following services are used to balance large mismatches on longer time scales, and therefore are tuned to high energy capacities rather than quick response times. A potential joint energy storage system includes supercapacitors for fast response times, with batteries for high energy capacity. Batteries would have sufficient energy storage capacities since microgrids are typically on the order of tens of megawatts [55]. Batteries, however, still fail to provide long duration, seasonal storage solutions.

\subsection{Current Work on Microgrids}

The U.S. Department of Energy - Office of Electricity (DOE-OE) is a proponent of microgrid technologies. DOE-OE's goal is to develop commercial microgrids in the tens of megawatt range, which would reduce outage times for essential loads, reduce GHG emissions, and improve energy efficiency. DOE-OE is working with several national laboratories on the design, planning, and architecture of microgrids, as well as their control and operation. Lawrence Berkeley National Laboratory is working on 
a model that minimizes the cost of micro-generators. The model works to find the optimal combination of energy generators and storage units tailored to a microgrid with a particular load, while reducing energy consumption and shaving the peak demand. Sandia National Laboratories developed the Microgrid Design Toolkit, which allows microgrid designers to search grid designs and identify alternate design decisions for microgrids and assess their impacts [56].

Designing, controlling, and modeling microgrids is an important focus in current work. It is a complex problem due to the nature of microgrids and their distributed generators. Control of microgrids is important for providing voltage and frequency regulation, optimum load-sharing among generators, switching between grid and island modes, optimizing operating cost, and handling transients. There are a number of control methods presented in the literature, each of which are optimized for different scenarios [57]. Design of microgrids is complex and dependent on the goal of the microgrid. Resiliency, cost, and environmental impact are some of the most important aspects considered when designing a system. Accurate modeling of microgrid design and operation is critical to developing an optimal design and operational control [58].

Microgrids have been gaining popularity in residential developments, such as one in Alabama that includes 62 homes powered with solar and natural gas [59]. Rural communities in developing countries, such as India, are another place where microgrid integration is gaining interest [60]. These rural communities are not powered by the main grid and have ample renewable energy resources, such as solar, that can be harvested on a small scale to power them. Research into design and optimization of these grids is ongoing, and they continue to improve in affordability and efficiency.

\subsection{Hybrid Energy Systems}

Hybrid energy systems use energy generated from various sources to provide electricity at lower costs, with reduced emissions, and with greater reliability than traditional single-source, electricity-only systems. Hybrid energy systems coordinate the use of different technologies to overcome the potential shortcomings of any single generation method. Possible energy sources that could be included in a hybrid system include solar, wind, nuclear, and fossil fuels. The intermittent nature of solar and wind can be accounted for with baseload production of nuclear and fossil fuels, where excess energy produced during times of high renewable availability or low demand can be directed to alternative energy users to produce a saleable commodity other than electricity. Fossil fuels are currently widely preferred in scenarios that call for flexible generation due to their ability to be ramped to meet changing load requirements (e.g., dispatchable), as well as their low operating costs. Dissimilar energy supply and demand in hybrid energy systems can also be accommodated with energy storage. Similar to microgrids, hybrid systems require both fast response and high-capacity energy storage.

The U.S. energy grid is becoming increasingly hybridized. The traditional dependence on fossil fuels such as coal and petroleum is giving way to more renewables, such as solar and wind, along with natural gas. Solar alone has gone from generating 864 gigawatt-hours (GWh) in 2008 to 52,958 GWh in 2017 [61]. Other renewable sources are also seeing increased integration, while the generation by coal is dropping. The rate of hybridization of the energy grid will likely slow due to the intermittent nature of renewable energy sources. Renewables do not provide constant or dispatchable power, are location dependent, and need a large geographic footprint mainly due to lower energy density [62].

Hybrid energy systems can utilize different energy generation technologies depending on their location, regional resource availability, and the load. Most energy generating technologies cannot be built in any location. Solar plants, for example, need high levels of solar irradiation; wind power needs both sustainable winds and a large footprint (on-land or off-shore, depending on the use location).

Conventional thermal plants using fossil fuels and nuclear do not have the same geographic restrictions as renewables. Using nuclear as the main energy source in locations where large-scale deployment of renewables isn't feasible is the best option for an emission-free grid. Traditional, large-scale nuclear plants may be limited in their siting options by the need for cooling water, but microreactors and other advanced reactors that do not require water for primary or secondary heat removal will experience fewer 
siting limitations. Currently, large scale nuclear plants have difficulty competing against low cost natural gas [61]. However, this is not a significant issue for microreactors since they are intended for deployment in unique environments where natural gas is generally not available. 


\section{GEOGRAPHIC CONSIDERATIONS}

The transportation of microreactors is a non-trivial task. Radioactive material transportation has historically been complicated by difficulties in finding arrangements that are mutually agreeable to stakeholders at the federal, state and community levels. Additionally, deployment to or transportation through non-U.S. territories could lead to further complications.

Compared to the current fleet, microreactors are expected to require more highly enriched, HALEU fuel (5\% - 20\% enriched) [63]. To date, large-scale shipments of HALEU have not occurred in the public arena. This is because the U.S. Department of Transportation (DOT) has not yet approved commercially viable cylinders or packages for material that is enriched to greater than 5\% U-235 [63]. A potentially viable solution for transport of HALEU or of reactor vessels containing HALEU maybe Type B packaging, which is currently used to transport highly radioactive materials such as spent nuclear fuel. Risk assessments conducted by the NRC to ascertain the safety of spent nuclear fuel transport using Type $\mathrm{B}$ casks have concluded that advancements in modeling tools have resulted in a reduction in the calculated per-shipment risks over the past 35 years [64]. Hence, Type B packaging is likely the best existing option for microreactor and HALEU transport, but it would still need to be qualified and licensed for such use.

Given the desire to deploy microreactors to remote or potentially hostile locations, proliferation risks need to be considered. These risks are minimized through the use of LEU. Additionally, physical security at the site of deployment will need to be considered for each use case as part of the licensing path, as will cyber security associated with the operation and potential remote monitoring of microreactors. It is important that microreactors be essentially impenetrable or have poisons in the fuel that further reduce proliferation risks. After deployment, a "set it and forget it" mentality would be ideal. To accomplish all these goals, strategies that employ a combination of autonomous control, remote monitoring, proper fuel design, and system encasement (either inherent from the factory or placement within one at the final destination) will likely be required.

An additional challenge with geographic mobility of microreactors to remote destinations is staffing requirements. Typical large-scale reactors require approximately 1,000 staff for 1,000 MWe produced [65]. Of these, approximately 100 staff are required for operations, with the rest being a combination of engineers, maintenance, etc. NuScale is currently working with the NRC to reduce operational staffing requirements for their plants [66]. Through elimination of plant systems, autonomous control, and smart design, NuScale will be able to drastically reduce staffing requirements. This could prove invaluable to microreactor technologies, as this will allow a path forward to acquire licensures to operate in remote locations with minimal staffing.

Further, depending on microreactor technology classification, research reactors across the country have set a precedent to operate facilities of this size with fewer staff. The North Carolina State University Pulstar reactor, for example, has an operational power of $1 \mathrm{MWth}$, employs a total staff of ten, including five operators [67]. The $6 \mathrm{MWth}$ reactor at the Massachusetts Institute of Technology has 15 operators in a total staff of 36 [67]. Thus, the ability to classify microreactors in the same field as research reactors could potentially further reduce staffing requirements and ultimately their economic viability. 


\section{DECISION SUPPORT FRAMEWORK}

This section summarizes operational factors that motivate the deployment of microreactors and provides a framework for the selection of reactor and balance of plant design, licensing path, and end use considerations that would help guide the development of this technology to its deployment. This framework will evolve as higher readiness levels are achieved and more information becomes available. Table 6.1 summarizes some of the motivating factors for deploying microreactors in certain use cases. Depending on the end user and purpose for a microreactor, various social, economic, environmental, or operational factors will influence the decision to deploy a reactor to support energy needs and, subsequently, what type of reactor and balance of plant system is most appropriate for the planned application.

Table 6.1. Motivating factors for microreactor deployment in certain use cases.

\begin{tabular}{|c|c|c|c|c|c|c|c|}
\hline \multirow[b]{2}{*}{ Use Case } & \multirow[b]{2}{*}{$\begin{array}{l}\text { Typical } \\
\text { Customer } \\
\text { (Decision } \\
\text { Maker) }\end{array}$} & \multirow[b]{2}{*}{$\begin{array}{c}\text { Social } \\
\text { Renewable } \\
\& \\
\text { Desalination } \\
\text { integration }\end{array}$} & \multirow[b]{2}{*}{\begin{tabular}{|c|} 
Economic \\
Fuel \& \\
cost \\
savings
\end{tabular}} & \multirow[b]{2}{*}{$\begin{array}{l}\text { Environmental } \\
\text { Reduce } \mathrm{CO}_{2} \\
\text { footprint }\end{array}$} & \multicolumn{3}{|c|}{ Operational } \\
\hline & & & & & $\begin{array}{l}\text { Fuel } \\
\text { independence }\end{array}$ & $\begin{array}{l}\text { Process } \\
\text { byproducts }\end{array}$ & $\begin{array}{l}\text { Uninterrupted } \\
\text { supply }\end{array}$ \\
\hline Rural Islands & $\begin{array}{l}\text { - Utility } \\
\text { - IPP }\end{array}$ & $\mathrm{XX}$ & XX & XX & XX & $\mathrm{x}$ & XX \\
\hline $\begin{array}{l}\text { Remote Civil } \\
\text { and DoD }\end{array}$ & $\begin{array}{l}\text { - Utility IIII } \\
\text { - IPP } \\
\text { - Government } \\
\text { - Development } \\
\text { institutions } \\
\text { - Government } \\
\text { Defense }\end{array}$ & $x \times$ & $x x$ & & $x \times$ & $x$ & \\
\hline Industrial & 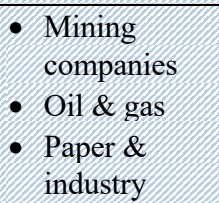 & & $x \times$ & $x$ & $x \times$ & $x \times$ & $x \times$ \\
\hline Defense & $\begin{array}{l}\text { Defense \& } \\
\text { DOE } \\
\text { CONus and } \\
\text { oconus }\end{array}$ & $x$ & $x$ & $x$ & $x \times$ & $x \times$ & $x \times$ \\
\hline $\begin{array}{l}\text { Urban } \\
\text { Communities }\end{array}$ & $\begin{array}{l}\text { - Utility } \\
\text { - IPP } \\
\text { - Educational } \\
\text { institutions } \\
\text { - Data centers }\end{array}$ & $\mathrm{XX}$ & $\mathrm{XX}$ & $\mathrm{XX}$ & & $\mathrm{x}$ & \\
\hline \multicolumn{6}{|c|}{$\begin{array}{ll}\mathrm{XX} & \text { Primary value proposition } \\
\mathrm{X} & \text { Secondary value proposition }\end{array}$} & \multicolumn{2}{|c|}{\begin{tabular}{|l|} 
Off-Grid or Grid-Connected \\
Grid-Connected
\end{tabular}} \\
\hline
\end{tabular}

In order to develop and deploy microreactors, a number of factors must be considered in parallel. When examining end uses, each use case has unique considerations which will help in the selection of a specific reactor system technology. When examining the specific reactor technologies, there are a number of factors that will influence development efforts, as well as the timeframe for deployment. Additionally, licensing considerations are of interest to both end users and reactor designers/developers. Figure 6.1 outlines some of the factors that will enable successful development and deployment of microreactors. These factors span a wide range, and include materials development, reactor and system modeling, and 
integration with microgrids and hybrid energy systems. As specific reactor designs and use cases are evaluated, a robust decision support framework will help ensure the requirements of the full system are addressed. Figure 6.1 summarizes the key considerations that will support selection of the most applicable technologies and associated licensing path for various use cases. This "framework" is subdivided into three equally important categories: reactor considerations, licensing, and end use considerations.

The deployment and operation of a microreactor needs to follow the guidelines and rules of a regulatory body (such as the NRC, DOE, or DoD), where the appropriate regulating body depends on the application. The "Reactor Considerations" category of Figure 6.1 can further be divided into three branches: materials, thermal-hydraulics, and neutronics, which are intimately coupled. For materials, the primary development efforts necessary to deploy a microreactor include testing, qualification, code case development, and manufacturability of individual components. Additionally, data on thermal stresses which result from transient events such as startup, shut down, and load following must be acquired. Thermal-hydraulics and neutronics analyses are inter-linked with each other due to fuel and coolant thermal response interactions.

Information on various subsystems is required to perform a fully integrated system analysis, and testing is required to perform verification and validation of design and modeling assumptions. The uncertainties in neutronic cross-section libraries need to be examined, and geometry dependence and flux (neutron spectrum) needs to be considered in a detailed neutronic analysis. Thus, in order to perform a detailed system analysis for a microreactor, having information on all three categories is critical. The decision framework proposed will evolve as more information is gathered on microreactors and other integration avenues mature and become available. 


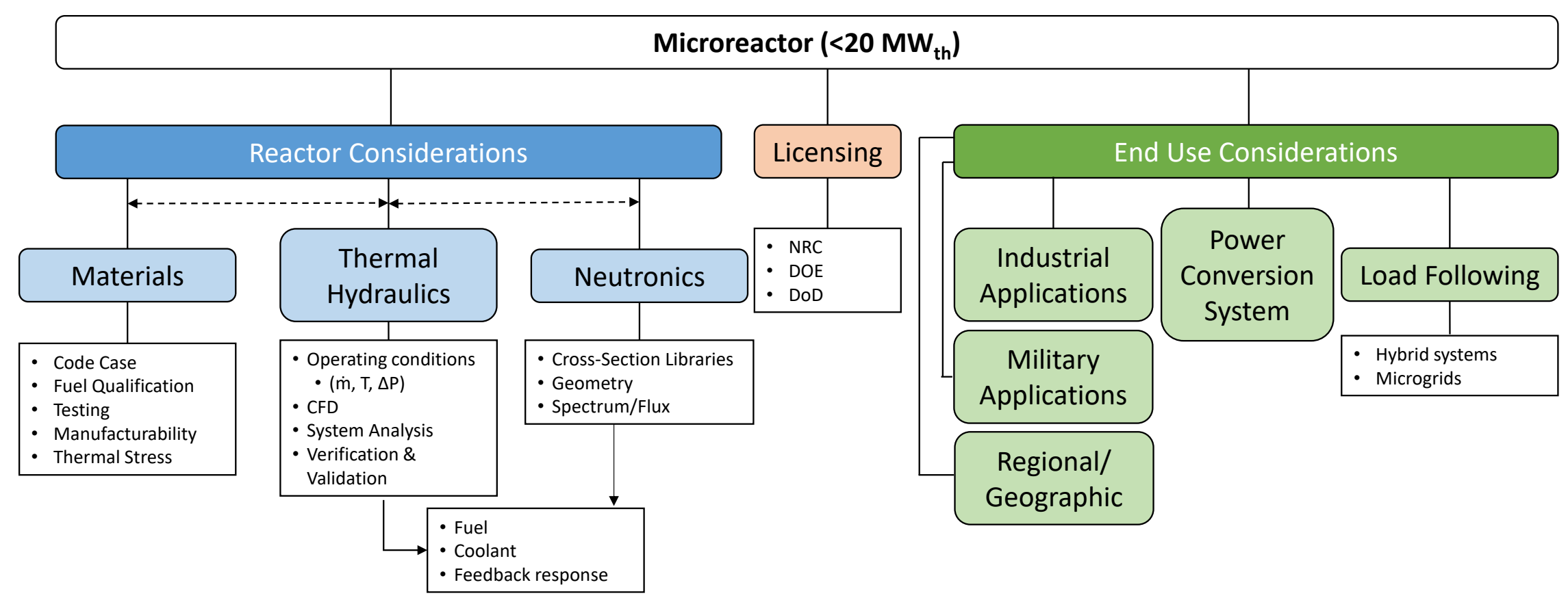

Figure 6.1. Decision support framework for microreactor development and deployment 


\section{CONCLUSIONS}

A microreactor is designed for use in unique applications where energy generation on the order of megawatts is otherwise unavailable or prohibitively expensive. These reactors generally produce less than 20 megawatt thermal (MWth), are factory manufacturable, easily transportable (e.g., truck, train, plane, or ship), and neutronically simple so as to allow for semi- or fully-autonomous operation.

Microreactors are currently being considered for multiple use cases, including:

- Military installations

- Remote community electricity production

- Industrial applications (e.g., desalination, hydrogen production, and chilled water production)

- Integration with hybrid energy systems and microgrids, while providing potential load following capabilities.

The end use applications of microreactors will depend on the regional/geographic location and needs, which will drive the requirements for reactor design. For example, these requirements may include the temperature required for industrial applications, which would further drive the selection of the coolant as well as the power conversion cycle to attain both higher thermal efficiency and maintain economic feasibility.

In the U.S., both HTGR and heat pipe microreactors are being considered at the MW scale. These reactors operate in different thermal regimes, and therefore allow for flexibility when selecting a reactor for a specific use case. Ongoing efforts to investigate materials, manufacturing techniques, and heat exchangers will allow for evaluation of TRLs and SRLs for specific reactor concepts. Those readiness level evaluations can then be used in conjunction with an expanded decision framework to define a path toward FOAK deployment. 


\section{REFERENCES}

[1] P. McClure, D. Poston, D. Rao and R. Reid, "Design of Megawatt Power Level Heat Pipe Reactors (LA-UR-15-28840)," Los Alamos National Laboratory, Los Alamos, NM, 2015.

[2] Defense Science Board, "Task Force on Energy Systems for Forward/Remote Operating Bases," Department of Defense, Washington, D.C., 2016.

[3] N. Hodge, "U.S.'s Afghan Headache: \$400-a-Gallon Gasoline," The Wall Street Journal, 6122011.

[4] C. Mooney, "Alaska's quest to power remote villages - and how it could spread clean energy worldwide," The Washington Post, 14 August 2015.

[5] International Atomic Energy Agency, "Advances in Nuclear Power Process Heat Applications (IAEA-TECDOC-1682)," International Atomic Energy Agency, Vienna, 2012.

[6] Office of the Assistant Secretary of Defense for Energy, Installations, and Environment, "Annual Energy Management and Resilience (AEMR) Report Fiscal Year 2016," Department of Defense, Washington, D.C., 2017.

[7] M. King, L. Huntzinger and T. Nguyen, "Feasibility of Nuclear Power on U.S. Military Installations," CNA, 2011.

[8] Deloitte, "Energy Security: America's Best Defense," Deloitte LLP, 2009.

[9] Alaska Energy Authority, "Power Cost Equalization Program: Statistical Data by Community," Alaska Energy Authority, Anchorage, Alaska, 2015.

[10] Alaska Department of Commerce, "Alaska Fuel Price Report: Current Community Conditions, July 2017," State of Alaska, Anchorage, Alaska, 2017.

[11] K. Murphy, "Ice halts delivery of winter fuel to Nome, Alaska," 2 December 2011. [Online]. Available: http://latimesblogs.latimes.com/nationnow/2011/12/nome-alaska-ice-fuel-crisis.html. [Accessed 17 September 2018].

[12] C. Hatch, "Self-Healing Microgrids to Help Keep Cordova, Alaska, Electrified," 2 January 2018. [Online]. Available: https://www.inl.gov/article/grid-resilience/. [Accessed 30 August 2018].

[13] Alaska Energy Authority, "Alaska Regional Energy Planning Map," [Online]. Available: http://www.akenergyauthority.org/Content/Policy/RegionalPlanning/Documents/AK_ER_ANCSA. pdf. [Accessed 24 August 2018].

[14] Alaska Energy Data Gateway, "Alaska Energy Statistics Summary Table 1.e - Net Generation by Certified Utilities (MWh)," 12 April 2016. [Online]. Available: https://akenergygateway.alaska.edu. [Accessed 24 August 2018].

[15] Paseidon Water, "Claude 'Bud' Lewis Carlsbad Desalination Plant," Carlsbad Desalination Project, 2017. [Online]. Available: https://www.carsbaddesal.com. [Accessed 25 August 2018].

[16] P. Rogers, "California Water: Desalination Projects Move Forward with New State Funding," The Mercury News, 29 January 2018.

[17] International Atomic Energy Agency, "Introduction of Nuclear Desalination: A Guidebook," IAEA, Vienna, 2000. 
[18] M. A. Darwish and N. M. Al-Najem, "Energy consumption by multi-stage flash and reverse osmosis desalters," Applied Thermal Engineering, vol. 20, no. 5, pp. 399-416, 2000.

[19] DOE Office of Energy Efficiency \& Renewable Energy, "Hydrogen Production: Natural Gas Reforming," Department of Energy, [Online]. Available:

https://www.energy.gov/eere/fuelcells/hydrogen-production-natural-gas-reforming. [Accessed 25 August 2018].

[20] United Nations, "Paris Agreement," United Nations, Paris, 2015.

[21] D. Ingersoll, Z. Houghton, R. Bromm, C. Desportes, M. McKellar and R. Boardman, "Extending Nuclear Energy to Non-Electrical Applications," in The 19th Pacific Basin Nuclear Conference (PBNC-2014), Vancouver, 2014.

[22] DOE Office of Energy Efficiency \& Renewable Energy, "Hydrogen Production: Electrolysis," DOE, [Online]. Available: https://www.energy.gov/eere/fuelcells/hydrogen-production-electrolysis. [Accessed 25 August 2018].

[23] J. S. Kim, S. M. Bragg-Sitton and R. D. Boardman, "Status Report on the High-Temperature Steam Electrolysis Plant Model Developed in the Modelica Framework (FY17) INL/EXT-17-43056," Idaho National Laboratory, Idaho Falls, ID, 2017.

[24] R. K. Suri, A. M. R. Al-Marafie, G. P. Maheshwari, F. Al-Juwayhel, S. Al-Jandal, K. Al-Madani and H. Aburshaid, "Experimental investigation of chilled water storage technique for peak power shaving," International Journal of Refrigeration, vol. 12, no. 4, pp. 213-219, 1989.

[25] A. M. R. Al-Marafie, "Stratification behaviour in a chilled water storage tank," International Journal of Refrigeration, vol. 10, no. 6, pp. 364-366, 1987.

[26] C. T. Misenheimer and S. D. Terry, "Modeling Hybrid Nuclear Systems with Chilled-Water Storage," ASME Journal of Energy Resources Technology, vol. 139, no. 1, 2017.

[27] R. Hamilton, "Lessons in emergency power preparedness: Planning in the wake of Katrina," Cummins Power Generation Inc., 2007.

[28] R. Kern, "Puerto Rico Eyed As Electricity Grid Innovation Testing Ground," Bloomberg Bureau of National Affairs, 26 September 2017.

[29] Diesel Service and Supply, "Approximate Diesel Fuel Consumption Chart," [Online]. Available: https://www.dieselserviceandsupply.com/Diesel_Fuel_Consumption.aspx. [Accessed 30 August 2018].

[30] World Nuclear News, "Canadian design review for StarCore HTGR," 8 November 2016. [Online]. Available: http://www.world-nuclear-news.org/NN-Canadian-design-review-for-StarCore-HTGR0811167.html. [Accessed 11 April 2018].

[31] D. C. Layman, T. A. DeRosier, K. F. Merten and J. W. Tenhundfeld, "XNJ140E Nuclear Turbojet Comprehensive Technical Report - Unclassified," General Electric Aircraft Nuclear Propulsion Program, Cincinnati, 1962.

[32] C. Filippone and K. A. Jordan, "The Holos Reactor: A Distributable Power Generator with Transportable Subcritical Power Modules," 25 June 2017. [Online]. Available: https://engrxiv.org/jzac9/. [Accessed 18 September 2018]. 
[33] HolosGen LLC, "HolosGen Technology," 2017. [Online]. Available: http://www.holosgen.com/technology/. [Accessed 15 May 2018].

[34] M. A. Gibson, S. R. Oleson, D. I. Poston and P. McClure, "NASA's Kilopower Reactor Development and the Path to Higher Power Missions," NASA, Cleveland, 2017.

[35] J. W. Sterbentz, J. E. Werner, A. J. Hummel, J. C. Kennedy, R. C. O'Brien, A. M. Dion, R. N. Wright and K. P. Ananth, "Preliminary Assessemnt of Two Alternative Core Design Concepts for the Special Purpose Reactor (INL/EXT-17-43212)," Idaho National Laboratory, Idaho Falls, ID, 2017.

[36] Westinghouse, "eVinci Micro Reactor," October 2017. [Online]. Available: http://www.westinghousenuclear.com/New-Plants/eVinci-Micro-Reactor. [Accessed 12 April 2018].

[37] J. W. Sterbentz, J. E. Werner, M. G. McKellar, A. J. Hummel, J. C. Kennedy, R. N. Wright and J. M. Biersdorf, "Special Purpose Nuclear Reactor (5 MW) for Reliable Power at Remote Sites Assessment Report Using Phenomena Identification and Ranking Tables (PIRTs)," Idaho National Laboratory, Idaho Falls, ID, 2017.

[38] Westinghouse, "Westinghouse Lead Fast Reactor," Westinghouse, August 2017. [Online]. Available: http:/www.westinghousenuclear.com/Portals/0/new\%20plants/LFR/ECOE0002_LeadFastReactor.pdf. [Accessed 12 April 2018].

[39] International Atomic Energy Agency, "Super-Safe, Small and Simple Reactor (4S, Toshiba Design)," Toshiba Corporation, 6 March 2013. [Online]. Available: https://aris.iaea.org/PDF/4S.pdf. [Accessed 12 April 2018].

[40] S. M. Bragg-Sitton, "Analysis of Space Reactor System Components: Investigation Through Simulation and Non-Nuclear Testing," Doctoral Dissertation, University of Michigan, Ann Arbor, MI, 2004.

[41] V. Dostal, M. J. Driscoll and P. Heizlar, "A Supercritical Carbon Dioxide Cycle for Next Generation Nuclear Plants, MIT-ANP-TR-100200," Massachusetts Institute of Technology, Cambridge, MA, 2004.

[42] P. Sabharwall, E. S. Kim, M. McKellar, N. Anderson and M. Patterson, "Process Heat Exchanger Options for the Advanced High Temperature Reactor, INL/EXT-11-21584," Idaho National Laboratory, Idaho Falls, ID, 2011.

[43] R. K. Shah and S. P. Sekulic, Fundamentals of Heat Exchanger Design, Hoboken, NJ: John Wiley \& Sons, Inc., 2003.

[44] M. G. McKellar and S. Bragg-Sitton, "Letter Report: Optimal Performance of Power Conversion Cycles and their Integration with Nuclear Reactors, INL/MIS-14-033253," Idaho National Laboratory, Idaho Falls, September 2014.

[45] G. J. Van Wylen and R. E. Sonntag, Fundamentals of Classical Thermodynmics, 2nd Ed., New York: John Wiley and Sons, Inc., 1973.

[46] M. Mohammadi, S. H. Hosseinian and G. B. Gharehpetian, "Optimal Sizing of Micro Grid \& Distributed Generation Units Under Pool Electricity Market," Journal of Renewables and Sustainable Energy, vol. 3, no. 5, 2011. 
[47] W. M. Taqqali and N. Abdulaziz, "Smart Grid and Demand Response Technology," in 2010 IEEE International Energy Conference, Manama, Bahrain, 2010.

[48] E. Miller, "Renewables and the Smart Grid," Renewable Energy Focus, vol. 10, no. 2, pp. 67-69, 2009.

[49] M. Panwar, G. P. Duggan, R. T. Griffen, S. Suryanarayanan, D. Zimmerle, M. Pool and S. Brunner, "Dispatch in Microgrids: Lessons from the Fort Collins Renewable and Distributed Systems Integration Demonstration Project," The Electricity Journal, vol. 25, no. 8, pp. 71-83, 2012.

[50] T. S. Ustun, C. Ozansoy and A. Zayegh, "Recent Developments in Microgrids and Example Cases Around the World - A Review," Renewable and Systainable Energy Reviews, vol. 15, no. 8, pp. 4030-4041, 2011.

[51] Microgrids at Berkeley Lab, "Examples of Microgrids - Hartley Bay," Berkely Lab, 2018. [Online]. Available: https://building-microgrid.lbl.gov/hartley-bay. [Accessed 14 August 2018].

[52] University of Alaska - Fairbanks, "Combined Heat and Power Plant," UAF, 10 July 2018. [Online]. Available: http://www.uaf.edu/heatandpower/. [Accessed 7 September 2018].

[53] Y. Guo and W. Gawlik, "A Survey of Control Strategies Applied in Worldwide Microgrid Projects," in ComForEn 2014 - 5th Symposium on Communications for Energy Systems, Eschenbachgasse, Astria, 2014.

[54] M. A. Moore and N. Gnanapragasam, "Energy Storage Coupled with VSMR for Remote Communities," in Pacific Basin Nuclear Conference, San Francisco, 2018.

[55] H. Zhou, T. Bhattacharya, D. Tran, T. S. T. Siew and A. M. Khambadkone, "Composite Energy Storage System Involving Battery and Ultracapacitor With Dynamic Energy Management in Microgrid Applications," IEEE Transactions on Power Electronics, vol. 26, no. 3, pp. 923-930, 2011.

[56] A. Lantero, "How Microgrids Work," U.S. Government, 17 June 2014. [Online]. Available: https://www.energy.gov/articles/how-microgrids-work. [Accessed 14 August 2018].

[57] A. Bidram, V. Nasirian, A. Davoudi and F. L. Lewis, Cooperative Synchronization in Distributed Microgrid Control, Springer, 2017.

[58] M. S. Mahmoud, S. A. Hussain and M. A. Abido, "Modeling and Control of Microgrid: An Overview," Journal of the Franklin Institute, vol. 351, no. 5, p. May, 2014.

[59] A. Soergel, "Alabama Microgrid Studies Future of Energy Infrastructure," U.S. News and World Report, 2 July 2018.

[60] V. K. Shankar, A. Gopikanna, S. Shankar, G. Rajan and V. Vijayaraghavan, "Intelligent System Design Optimization with Dynamic Load Profile for a Stand-Alone Rural Indian Microgrid," in 2018 IEEE Texas Power and Energy Conference, College Station, TX, 2018.

[61] U.S. Energy Information Administration, "Electric Power Monthly with Data for May 2018," U.S. EIA, Washington, D.C., 2018.

[62] S. Suman, "Hybrid Nuclear-Renewable Energy Systems: A Review," Journal of Cleaner Production, vol. 181, pp. 166-177, 2018. 
[63] M. Tschiltz, "Addressing the Challenges with Establishing the Infrastructure for the Front-end of the Fuel Cycle for Advanced Reactors," 2017.

[64] U.S. Nuclear Regulartory Commission, "NUREG-2125 Spent Fuel Transportation Risk Assessment," NRC, Washington, D.C., 2014.

[65] International Atomic Energy Agency, "Nuclear Power Plant Organization and Staffing for Improved Performance: Lessons Learned (IAEA-TECDOC-1052)," IAEA, Vienna, Austria, 1998.

[66] NuScale Power, "Letter from NuScale Power, LLC to U.S. Nuclear Regulatory Commission, "NuScale Power, LLC Submittal of a Second Set of Human Factors Engineering (HFE) Implementation Plans," 14 March 2016. [Online]. Available: https://www.nrc.gov/docs/ML1607/ML16074A434.pdf. [Accessed 7 September 2018].

[67] International Atomic Energy Agency, "Research Reactor Database," IAEA, [Online]. Available: https://nucleus.iaea.org/rrdb/Content/Geo/Country.aspx?iso=US. [Accessed 9 September 2018]. 


\section{Appendix A \\ DoD Installation Energy Use}


Appendix A

DoD Installation Energy Use

The table below identifies energy use at DoD installations in 2016. Total annual energy use data is taken from the FY2016 DoD Annual Energy Management and Resilience (AEMR) Report [6]. Total energy use in mega-joules is divided by the number of seconds in the year 2016 ( 366 days * 24 hours/day * 60 minutes/hour * 60 seconds/minute) to give the average energy demand at the site in mega-watts. Note that this data only gives the average energy demand during 2016, and does not reflect the variability in demand or peak demand.

Table A.1. DoD installation energy use 2016.

\begin{tabular}{|c|c|c|c|c|c|}
\hline Component & Installation Name & City & State / Country & $\begin{array}{c}\text { Total Site } \\
\text { Delivered } \\
\text { Energy } \\
\text { (BBTU) Goal } \\
\text { Subject } \\
\end{array}$ & $\begin{array}{c}\text { Annual } \\
\text { Average } \\
\text { Site Energy } \\
\text { (MWe) }\end{array}$ \\
\hline AIR FORCE & ANDERSEN AIR FORCE BASE & FPO & GUAM & 3 & 0.10 \\
\hline NAVY & NSA SARATOGA SPRINGS NY & SARATOGA SPRINGS & NEW YORK & 3 & 0.10 \\
\hline AIR FORCE & $\begin{array}{l}\text { CAMP PENDLETON MILITARY } \\
\text { RESERVATION(ANG) }\end{array}$ & VIRGINIA BEACH & VIRGINIA & 4 & 0.13 \\
\hline AIR FORCE & CAMP PERRY ANG STATION & PORT CLINTON & $\mathrm{OHIO}$ & 4 & 0.13 \\
\hline AIR FORCE & NORTH HIGHLANDS ANG STATION & NORTH HIGHLANDS & CALIFORNIA & 5 & 0.17 \\
\hline AIR FORCE & $\begin{array}{l}\text { CAMP BLANDING MILITARY } \\
\text { RESERVATION (ANG) }\end{array}$ & STARKE & FLORIDA & 6 & 0.20 \\
\hline ARMY & 9TH MISSION SUPPORT COMMAND & HONOLULU & HAWAII & 7 & 0.23 \\
\hline DCMA & $\operatorname{DCMA}(2)$ & BRATENAHL & $\mathrm{OHIO}$ & 8.75 & 0.29 \\
\hline DCMA & $\operatorname{DCMA}(1)$ & CARSON & CALIFORNIA & 9.23 & 0.31 \\
\hline DFAS & DFAS LIMESTONE & LIMESTONE & MAINE & 10 & 0.33 \\
\hline ARMY & GUAM ARNG (MOB) & FPO & GUAM & 10 & 0.33 \\
\hline AIR FORCE & LAMBERT ST LOUIS IAP ANG & ST. LOUIS & MISSOURI & 10 & 0.33 \\
\hline AIR FORCE & CAMP MURRAY ANG STATION & TACOMA & WASHINGTON & 11 & 0.37 \\
\hline ARMY & MILITARY OCEAN TML & CONCORD & CALIFORNIA & 11 & 0.37 \\
\hline AIR FORCE & MOFFETT FLD ANG & MOUNTAIN VIEW & CALIFORNIA & 11 & 0.37 \\
\hline AIR FORCE & $\begin{array}{l}\text { FT INDIANTOWN GAP ANG } \\
\text { STATION }\end{array}$ & ANNVILLE & PENNSYLVANIA & 12 & 0.40 \\
\hline
\end{tabular}


Table A.1 (continued)

\begin{tabular}{|c|c|c|c|c|c|}
\hline Component & Installation Name & City & State / Country & \begin{tabular}{|c|} 
Total Site \\
Delivered \\
Energy \\
(BBTU) Goal \\
Subject \\
\end{tabular} & $\begin{array}{c}\text { Annual } \\
\text { Average } \\
\text { Site Energy } \\
\text { (MWe) } \\
\end{array}$ \\
\hline AIR FORCE & $\begin{array}{l}\text { JEFFERSON BARRACKS ANG } \\
\text { STATION }\end{array}$ & LEMAY & MISSOURI & 12 & 0.40 \\
\hline ARMY & VIRGIN ISLANDS ARNG (MOB) & FPO & VIRGIN ISLANDS & 12 & 0.40 \\
\hline AIR FORCE & $\begin{array}{l}\text { NIAGARA FALLS IAP-AIR RESERVE } \\
\text { STATION (ANG) }\end{array}$ & NIAGARA FALLS & NEW YORK & 13 & 0.43 \\
\hline AIR FORCE & CARSWELL AIR RESERVE STATION & FORT WORTH & TEXAS & 14 & 0.47 \\
\hline AIR FORCE & CHANNEL ISLANDS ANG STATION & PORT HUENEME & CALIFORNIA & 16 & 0.53 \\
\hline AIR FORCE & $\begin{array}{l}\text { FAIRCHILD AIR FORCE BASE } \\
\text { (ANG) }\end{array}$ & AIRWAY HEIGHTS & WASHINGTON & 16 & 0.53 \\
\hline AIR FORCE & $\begin{array}{l}\text { FRESNO YOSEMITE } \\
\text { INTERNATIONAL }\end{array}$ & FRESNO & CALIFORNIA & 16 & 0.53 \\
\hline ARMY & MOT SUNNY POINT & SOUTHPORT & NORTH CAROLINA & 16 & 0.53 \\
\hline NAVY & NAVMAG INDIAN ISLAND WA & PORT HADLOCK & SOUTH CAROLINA & 16 & 0.53 \\
\hline DIA & DLOC WAREHOUSE & LANDOVER & MARYLAND & 17 & 0.57 \\
\hline AIR FORCE & KIRTLAND AIR FORCE BASE & ALBUQUERQUE & NEW MEXICO & 18 & 0.60 \\
\hline AIR FORCE & $\begin{array}{l}\text { SKY HARBOR INTERNATIONAL } \\
\text { AIRPORT }\end{array}$ & PHOENIX & ARIZONA & 18 & 0.60 \\
\hline AIR FORCE & LITTLE ROCK AIR FORCE BASE & LITTLE ROCK & ARKANSAS & 19 & 0.63 \\
\hline AIR FORCE & $\begin{array}{l}\text { BURLINGTON INTERNATIONAL } \\
\text { AIRPORT (ANG) }\end{array}$ & $\begin{array}{l}\text { SOUTH } \\
\text { BURLINGTON }\end{array}$ & VERMONT & 20 & 0.67 \\
\hline ARMY & MILAN AAP (GOCO) & MILAN & TENNESSEE & 20 & 0.67 \\
\hline AIR FORCE & $\begin{array}{l}\text { NASHVILLE INTERNATIONAL } \\
\text { AIRPORT }\end{array}$ & NASHVILLE & TENNESSEE & 20 & 0.67 \\
\hline AIR FORCE & $\begin{array}{l}\text { RENO TAHOE INTERNATIONAL } \\
\text { AIRPORT }\end{array}$ & RENO & NEVADA & 20 & 0.67 \\
\hline AIR FORCE & $\begin{array}{l}\text { ABRAHAM LINCOLN CAPITAL } \\
\text { AIRPORT }\end{array}$ & SPRINGFIELD & ILLINOIS & 21 & 0.70 \\
\hline
\end{tabular}


Table A.1 (continued)

\begin{tabular}{|c|c|c|c|c|c|}
\hline Component & Installation Name & City & State / Country & $\begin{array}{c}\text { Total Site } \\
\text { Delivered } \\
\text { Energy } \\
\text { (BBTU) Goal } \\
\text { Subject } \\
\end{array}$ & $\begin{array}{c}\text { Annual } \\
\text { Average } \\
\text { Site Energy } \\
\text { (MWe) }\end{array}$ \\
\hline AIR FORCE & $\begin{array}{l}\text { FORT SMITH MUNICIPAL AIRPORT } \\
\text { ANG }\end{array}$ & FORT SMITH & ARKANSAS & 21 & 0.70 \\
\hline AIR FORCE & TOLEDO EXPRESS AIRPORT ANG & SWANTON & $\mathrm{OHIO}$ & 21 & 0.70 \\
\hline AIR FORCE & HARRISBURG IAP & MIDDLETOWN & PENNSYLVANIA & 22 & 0.73 \\
\hline AIR FORCE & ROSECRANS MEMORIAL AIRPORT & ST. JOSEPH & MISSOURI & 22 & 0.73 \\
\hline NAVY & NSA ORLANDO FL & ORLANDO & FLORIDA & 23 & 0.77 \\
\hline AIR FORCE & $\begin{array}{l}\text { AIR NATIONAL GUARD } \\
\text { READINESS } \\
\text { CENTER (ANGrc) }\end{array}$ & ANDREWS AFB & MARYLAND & 24 & 0.80 \\
\hline AIR FORCE & $\begin{array}{l}\text { BRADLEY INTERNATIONAL } \\
\text { AIRPORT (ANG) }\end{array}$ & WINDSOR LOCKS & CONNECTICUT & 24 & 0.80 \\
\hline ARMY & HAWAII ARNG & HONOLULU & HAWAII & 24 & 0.80 \\
\hline AIR FORCE & $\begin{array}{l}\text { LOUISVILLE INTERNATIONAL } \\
\text { AIRPORT - STANDIFORD FIELD }\end{array}$ & LOUISVILLE & KENTUCKY & 24 & 0.80 \\
\hline AIR FORCE & NEW CASTLE COUNTY AIRPORT & WILMINGTON & DELAWARE & 24 & 0.80 \\
\hline DFAS & DFAS ROME & ROME & NEW YORK & 25 & 0.83 \\
\hline AIR FORCE & MARTIN STATE AIRPORT ANG & MIDDLE RIVER & MARYLAND & 25 & 0.83 \\
\hline AIR FORCE & WILL ROGERS WORLD AIRPORT & OKLAHOMA CITY & OKLAHOMA & 25 & 0.83 \\
\hline AIR FORCE & EIELSON AIR FORCE BASE & MOOSE CREEK & ALASKA & 26 & 0.87 \\
\hline AIR FORCE & JACKSONVILLE IAP ANG & JACKSONVILLE & FLORIDA & 26 & 0.87 \\
\hline NAVY & CFA CHINHAE KOR & FPO & $\begin{array}{l}\text { KOREA, REPUBLIC } \\
\text { OF }\end{array}$ & 27 & 0.90 \\
\hline AIR FORCE & KEY FIELD AIR NATIONAL GUARD & MERIDIAN & MISSISSIPPI & 27 & 0.90 \\
\hline AIR FORCE & $\begin{array}{l}\text { LUIS MUNOZ MARIN } \\
\text { INTERNATIONAL AIRPORT }\end{array}$ & CAROLINA & PUERTO RICO & 27 & 0.90 \\
\hline AIR FORCE & $\begin{array}{l}\text { BIRMINGHAM INTERNATIONAL } \\
\text { AIRPORT }\end{array}$ & BIRMINGHAM & ALABAMA & 28 & 0.93 \\
\hline
\end{tabular}


Table A.1 (continued)

\begin{tabular}{|c|c|c|c|c|c|}
\hline Component & Installation Name & City & State / Country & $\begin{array}{c}\text { Total Site } \\
\text { Delivered } \\
\text { Energy } \\
\text { (BBTU) Goal } \\
\text { Subject } \\
\end{array}$ & $\begin{array}{c}\text { Annual } \\
\text { Average } \\
\text { Site Energy } \\
\text { (MWe) }\end{array}$ \\
\hline AIR FORCE & BOISE AIR TERMINAL (ANG) & BOISE & IDAHO & 28 & 0.93 \\
\hline AIR FORCE & $\begin{array}{l}\text { GENERAL MITCHELL } \\
\text { INTERNATIONAL APT (ANG) }\end{array}$ & MILWAUKEE & WISCONSIN & 28 & 0.93 \\
\hline USMC & MCB CAMP MUJUK & FPO & SOUTH KOREA & 29 & 0.97 \\
\hline AIR FORCE & $\begin{array}{l}\text { CHARLOTTE/DOUGLAS INT } \\
\text { AIRPORT (ANG) }\end{array}$ & CHARLOTTE & NORTH CAROLINA & 30 & 1.00 \\
\hline AIR FORCE & $\begin{array}{l}\text { KELLY FIELD ANNEX (LACKLAND } \\
\text { AFB) }\end{array}$ & LACKLAND AFB & TEXAS & 30 & 1.00 \\
\hline AIR FORCE & MORON AIR BASE & FPO & SPAIN & 30 & 1.00 \\
\hline ARMY & NEW HAMPSHIRE ARNG & CONCORD & NEW HAMPSHIRE & 30 & 1.00 \\
\hline NRO & NROV & LOMPOC & CALIFORNIA & 30 & 1.00 \\
\hline AIR FORCE & $\begin{array}{l}\text { DANE COUNTY REGIONAL } \\
\text { AIRPORT-TRUAX FIELD }\end{array}$ & MADISON & WISCONSIN & 31 & 1.03 \\
\hline ARMY & DELAWARE ARNG & WILMINGTON & DELAWARE & 31 & 1.03 \\
\hline AIR FORCE & GREAT FALLS IAP ANG & GREAT FALLS & MONTANA & 31 & 1.03 \\
\hline AIR FORCE & $\begin{array}{l}\text { LINCOLN MUNICIPAL AIRPORT } \\
\text { (ANG) }\end{array}$ & LINCOLN & NEBRASKA & 31 & 1.03 \\
\hline ARMY & NEVADA ARNG & CARSON CITY & NEVADA & 31 & 1.03 \\
\hline NAVY & SINGAPORE AREA COORDINATOR & FPO & SINGAPORE & 31 & 1.03 \\
\hline AIR FORCE & $\begin{array}{l}\text { GENERAL WAYNE A. DOWNING } \\
\text { PEORIA INTERNATIONAL AIRPORT } \\
\text { (ANG) }\end{array}$ & PEORIA & ILLINOIS & 32 & 1.07 \\
\hline AIR FORCE & $\begin{array}{l}\text { GULFPORT-BILOXI REGIONAL } \\
\text { AIRPORT (ANG) }\end{array}$ & GULFPORT & MISSISSIPPI & 32 & 1.07 \\
\hline AIR FORCE & $\begin{array}{l}\text { MONTGOMERY REGIONAL } \\
\text { AIRPORT (ANG) BASE }\end{array}$ & MONTGOMERY & ALABAMA & 32 & 1.07 \\
\hline
\end{tabular}


Table A.1 (continued)

\begin{tabular}{|c|c|c|c|c|c|}
\hline Component & Installation Name & City & State / Country & $\begin{array}{c}\text { Total Site } \\
\text { Delivered } \\
\text { Energy } \\
\text { (BBTU) Goal } \\
\text { Subject } \\
\end{array}$ & $\begin{array}{c}\text { Annual } \\
\text { Average } \\
\text { Site Energy } \\
\text { (MWe) } \\
\end{array}$ \\
\hline AIR FORCE & $\begin{array}{l}\text { SPRINGFIELD BECKLEY } \\
\text { MUNICIPAL } \\
\text { AIRPORT }\end{array}$ & SPRINGFIELD & $\mathrm{OHIO}$ & 32 & 1.07 \\
\hline AIR FORCE & $\begin{array}{l}\text { BARNES MUNICIPAL AIRPORT } \\
\text { ANG }\end{array}$ & WESTFIELD & MASSACHUSETTS & 33 & 1.10 \\
\hline AIR FORCE & $\begin{array}{l}\text { FRANCIS S GABRESKI AIRPORT } \\
\text { (ANG) }\end{array}$ & $\begin{array}{l}\text { WESTHAMPTON } \\
\text { BEACH }\end{array}$ & NEW YORK & 33 & 1.10 \\
\hline USMC & MCSF BLOUNT ISLAND FL & JACKSONVILLE & FLORIDA & 33 & 1.10 \\
\hline AIR FORCE & NEW ORLEANS NAS ANG & BELLE CHASSE & LOUISIANA & 33 & 1.10 \\
\hline ARMY & PUEBLO CHEMICAL DEPOT & PUEBLO & COLORADO & 33 & 1.10 \\
\hline AIR FORCE & $\begin{array}{l}\text { DES MOINES INTERNATIONAL } \\
\text { AIRPORT ANG }\end{array}$ & DES MOINES & IOWA & 34 & 1.13 \\
\hline AIR FORCE & QUONSET STATE AIRPORT ANG & NORTH KINGSTOWN & RHODE ISLAND & 34 & 1.13 \\
\hline DIA & $\begin{array}{l}\text { ROWE BUILDING AND ULC } \\
\text { 1/RIVANNA STATION }\end{array}$ & CHARLOTTESVILLE & VIRGINIA & 34 & 1.13 \\
\hline ARMY & WASHINGTON ARNG & CAMP MURRAY & WASHINGTON & 34 & 1.13 \\
\hline AIR FORCE & $\begin{array}{l}\text { HECTOR INTERNATIONAL } \\
\text { AIRPORT } \\
\text { (ANG) }\end{array}$ & FARGO & NORTH DAKOTA & 35 & 1.17 \\
\hline AIR FORCE & HICKAM AIR FORCE BASE & HICKAM AF BASE & HAWAII & 35 & 1.17 \\
\hline NAVY & NSA SOUDA BAY GR & FPO & GREECE & 35 & 1.17 \\
\hline AIR FORCE & RAF FAIRFORD & FPO & UNITED KINGDOM & 35 & 1.17 \\
\hline AIR FORCE & SCOTT AIR FORCE BASE (ANG) & BELLEVILLE & ILLINOIS & 35 & 1.17 \\
\hline AIR FORCE & $\begin{array}{l}\text { SIOUX GATEWAY AP/COL. BUD } \\
\text { DAY FIELD(ANG) }\end{array}$ & SIOUX CITY & IOWA & 35 & 1.17 \\
\hline AIR FORCE & $\begin{array}{l}\text { FORT WAYNE INTERNATIONAL } \\
\text { AIRPORT }\end{array}$ & FORT WAYNE & INDIANA & 36 & 1.20 \\
\hline
\end{tabular}


Table A.1 (continued)

\begin{tabular}{|c|c|c|c|c|c|}
\hline Component & Installation Name & City & State / Country & $\begin{array}{c}\text { Total Site } \\
\text { Delivered } \\
\text { Energy } \\
\text { (BBTU) Goal } \\
\text { Subject } \\
\end{array}$ & $\begin{array}{c}\text { Annual } \\
\text { Average } \\
\text { Site Energy } \\
\text { (MWe) } \\
\end{array}$ \\
\hline AIR FORCE & $\begin{array}{l}\text { MCENTIRE JOINT NATIONAL } \\
\text { GUARD BASE }\end{array}$ & EASTOVER & SOUTH CAROLINA & 36 & 1.20 \\
\hline AIR FORCE & $\begin{array}{l}\text { MINNEAPOLIS-ST PAUL IAP-AIR } \\
\text { RESERVE STN (ANG) }\end{array}$ & MINNEAPOLIS & MINNESOTA & 36 & 1.20 \\
\hline AIR FORCE & $\begin{array}{l}\text { SCHENECTADY COUNTY AIRPORT } \\
\text { ANG }\end{array}$ & SCOTIA & NEW YORK & 36 & 1.20 \\
\hline AIR FORCE & FORBES FIELD ANG & TOPEKA & KANSAS & 37 & 1.23 \\
\hline AIR FORCE & MANSFIELD LAHM AIRPORT ANG & MANSFIELD & $\mathrm{OHIO}$ & 37 & 1.23 \\
\hline AIR FORCE & TULSA INTERNATIONAL AIRPORT & TULSA & OKLAHOMA & 37 & 1.23 \\
\hline AIR FORCE & W K KELLOGG AIRPORT & BATTLE CREEK & MICHIGAN & 37 & 1.23 \\
\hline AIR FORCE & $\begin{array}{l}\text { KLAMATH FALLS AIRPORT- } \\
\text { KINGSLEY FIELD }\end{array}$ & KLAMATH FALLS & OREGON & 38 & 1.27 \\
\hline ARMY & PUERTO RICO ARNG (MOB) & SAN JUAN & PUERTO RICO & 38 & 1.27 \\
\hline AIR FORCE & JOE FOSS FIELD ANG & SIOUX FALLS & SOUTH DAKOTA & 39 & 1.30 \\
\hline AIR FORCE & $\begin{array}{l}\text { WILLOW GROVE AIR RESERVE } \\
\text { STATION }\end{array}$ & HORSHAM & PENNSYLVANIA & 39 & 1.30 \\
\hline AIR FORCE & YEAGER AIRPORT ANG & CHARLESTON & WEST VIRGINIA & 40 & 1.33 \\
\hline AIR FORCE & $\begin{array}{l}\text { ATLANTIC CITY INTERNATIONAL } \\
\text { AIRPORT }\end{array}$ & $\begin{array}{l}\text { EGG HARBOR } \\
\text { TOWNSHIP }\end{array}$ & NEW JERSEY & 41 & 1.37 \\
\hline AIR FORCE & CHEYENNE REGIONAL AIRPORT & CHEYENNE & WYOMING & 42 & 1.40 \\
\hline AIR FORCE & VOLK FIELD & CAMP DOUGLAS & WISCONSIN & 42 & 1.40 \\
\hline AIR FORCE & $\begin{array}{l}\text { BANGOR INTERNATIONAL } \\
\text { AIRPORT (ANG) }\end{array}$ & BANGOR & MAINE & 43 & 1.43 \\
\hline AIR FORCE & ELLINGTON FIELD & HOUSTON & TEXAS & 43 & 1.43 \\
\hline USMC & MCAS CAMP PENDLETON CA & CAMP PENDLETON & CALIFORNIA & 43 & 1.43 \\
\hline USMC & NAVAL HOSPITAL 29 PALMS CA & $\begin{array}{l}\text { TWENTYNINE } \\
\text { PALMS }\end{array}$ & CALIFORNIA & 43 & 1.43 \\
\hline
\end{tabular}


Table A.1 (continued)

\begin{tabular}{|c|c|c|c|c|c|}
\hline Component & Installation Name & City & State / Country & $\begin{array}{c}\text { Total Site } \\
\text { Delivered } \\
\text { Energy } \\
\text { (BBTU) Goal } \\
\text { Subject } \\
\end{array}$ & $\begin{array}{c}\text { Annual } \\
\text { Average } \\
\text { Site Energy } \\
\text { (MWe) } \\
\end{array}$ \\
\hline AIR FORCE & $\begin{array}{l}\text { RICKENBACKER INTERNATION } \\
\text { AIRPORT (ANG) }\end{array}$ & COLUMBUS & $\mathrm{OHIO}$ & 43 & 1.43 \\
\hline ARMY & PARKS CSTC & DUBLIN & CALIFORNIA & 44 & 1.47 \\
\hline AIR FORCE & $\begin{array}{l}\text { PITTSBURGH IAP-AIR RESERVE } \\
\text { STN }\end{array}$ & MOON & PENNSYLVANIA & 44 & 1.47 \\
\hline AIR FORCE & $\begin{array}{l}\text { SALT LAKE CITY INTERNATIONAL } \\
\text { AIRPORT ANG }\end{array}$ & SALT LAKE CITY & UTAH & 44 & 1.47 \\
\hline ARMY & DC ARNG (MOB) & WASHINGTON & $\begin{array}{l}\text { DISTRICT OF } \\
\text { COLUMBIA }\end{array}$ & 45 & 1.50 \\
\hline NRO & GLEN & SCHRIEVER AFB & COLORADO & 45 & 1.50 \\
\hline AIR FORCE & $\begin{array}{l}\text { SAVANNAH/HILTON HEAD } \\
\text { INTERNATIONAL AP }\end{array}$ & GARDEN CITY & GEORGIA & 45 & 1.50 \\
\hline ARMY & FORT HUNTER LIGGETT & $\begin{array}{l}\text { FORT HUNTER } \\
\text { LIGGETT }\end{array}$ & CALIFORNIA & 46 & 1.53 \\
\hline USMC & MCMWTC BRIDGEPORT CA & BRIDGEPORT & CALIFORNIA & 46 & 1.53 \\
\hline AIR FORCE & HULMAN REGIONAL AIRPORT & TERRE HAUTE & INDIANA & 47 & 1.57 \\
\hline AIR FORCE & $\begin{array}{l}\text { JOINT BASE ANDREWS-NAVAL AIR } \\
\text { FACILITY WASHINGTON }\end{array}$ & ANDREWS AFB & MARYLAND & 48 & 1.60 \\
\hline USMC & MARBKS WASHINGTON DC & WASHINGTON & $\begin{array}{l}\text { DISTRICT OF } \\
\text { COLUMBIA }\end{array}$ & 48 & 1.60 \\
\hline AIR FORCE & $\begin{array}{l}\text { TUCSON INTERNATIONAL } \\
\text { AIRPORT }\end{array}$ & TUCSON & ARIZONA & 48 & 1.60 \\
\hline AIR FORCE & SYRACUSE HANCOCK FIELD ANG & SYRACUSE & NEW YORK & 49 & 1.63 \\
\hline ARMY & MAINE ARNG & CAMP KEYES & MAINE & 50 & 1.67 \\
\hline AIR FORCE & MCGUIRE AIR FORCE BASE (ANG) & MCGUIRE AFB & NEW JERSEY & 50 & 1.67 \\
\hline AIR FORCE & MARCH AIR RESERVE BASE (ANG) & RIVERSIDE & CALIFORNIA & 51 & 1.70 \\
\hline ARMY & VERMONT ARNG & COLCHESTER & VERMONT & 51 & 1.70 \\
\hline
\end{tabular}


Table A.1 (continued)

\begin{tabular}{|c|c|c|c|c|c|}
\hline Component & Installation Name & City & State / Country & $\begin{array}{c}\text { Total Site } \\
\text { Delivered } \\
\text { Energy } \\
\text { (BBTU) Goal } \\
\text { Subject } \\
\end{array}$ & $\begin{array}{c}\text { Annual } \\
\text { Average } \\
\text { Site Energy } \\
\text { (MWe) } \\
\end{array}$ \\
\hline AIR FORCE & $\begin{array}{l}\text { DULUTH INTERNATIONAL } \\
\text { AIRPORT } \\
\text { (ANG) }\end{array}$ & DULUTH & MINNESOTA & 52 & 1.73 \\
\hline AIR FORCE & $\begin{array}{l}\text { JACKSON INTERNATIONAL } \\
\text { AIRPORT }\end{array}$ & FLOWOOD & MISSISSIPPI & 52 & 1.73 \\
\hline NAVY & CFA OKINAWA JA & FPO & JAPAN & 54 & 1.80 \\
\hline AIR FORCE & $\begin{array}{l}\text { JOINT BASE ELMENDORF-FT } \\
\text { RICHARDSON }\end{array}$ & ELMENDORF AFB & ALASKA & 55 & 1.84 \\
\hline AIR FORCE & LAJES FIELD & FPO & PORTUGAL & 56 & 1.87 \\
\hline AIR FORCE & $\begin{array}{l}\text { PITTSBURGH INTERNATIONAL } \\
\text { AIRPORT (ANG) }\end{array}$ & CORAOPOLIS & PENNSYLVANIA & 56 & 1.87 \\
\hline ARMY & SOUTH DAKOTA ARNG & RAPID CITY & SOUTH DAKOTA & 56 & 1.87 \\
\hline AIR FORCE & $\begin{array}{l}\text { ALPENA COUNTY REGIONAL } \\
\text { AIRPORT }\end{array}$ & ALPENA & MICHIGAN & 57 & 1.90 \\
\hline AIR FORCE & OTIS AIR NATIONAL GUARD BASE & $\begin{array}{l}\text { OTIS ANGB, } \\
\text { MASHPEE }\end{array}$ & MASSACHUSETTS & 57 & 1.90 \\
\hline ARMY & RHODE ISLAND ARNG & CRANSTON & RHODE ISLAND & 57 & 1.90 \\
\hline NAVY & NAF MISAWA JA & FPO & JAPAN & 59 & 1.97 \\
\hline AIR FORCE & $\begin{array}{l}\text { PORTLAND INTERNATIONAL } \\
\text { AIRPORT }\end{array}$ & PORTLAND & OREGON & 59 & 1.97 \\
\hline ARMY & NEW MEXICO ARNG & SANTA FE & NEW MEXICO & 60 & 2.00 \\
\hline USMC & CATC CAMP FUJI JA & FPO & JAPAN & 63 & 2.10 \\
\hline AIR FORCE & HOMESTEAD AIR RESERVE BASE & HOMESTEAD & FLORIDA & 63 & 2.10 \\
\hline ARMY & FORT HAMILTON & NEW YORK CITY & NEW YORK & 65 & 2.17 \\
\hline AIR FORCE & $\begin{array}{l}\text { MCCONNELL AIR FORCE BASE } \\
\text { (ANG) }\end{array}$ & WICHITA & KANSAS & 65 & 2.17 \\
\hline
\end{tabular}


Table A.1 (continued)

\begin{tabular}{|c|c|c|c|c|c|}
\hline Component & Installation Name & City & State / Country & \begin{tabular}{|c|} 
Total Site \\
Delivered \\
Energy \\
(BBTU) Goal \\
Subject \\
\end{tabular} & $\begin{array}{c}\text { Annual } \\
\text { Average } \\
\text { Site Energy } \\
\text { (MWe) } \\
\end{array}$ \\
\hline AIR FORCE & $\begin{array}{l}\text { MEMPHIS INTERNATIONAL } \\
\text { AIRPORT }\end{array}$ & MEMPHIS & TENNESSEE & 65 & 2.17 \\
\hline AIR FORCE & $\begin{array}{l}\text { MINNEAPOLIS-ST PAUL IAP-AIR } \\
\text { RESERVE STN (AFR) }\end{array}$ & MINNEAPOLIS & MINNESOTA & 66 & 2.20 \\
\hline ARMY & ALASKA ARNG & FORT RICHARDSON & ALASKA & 67 & 2.24 \\
\hline ARMY & ARIZONA ARNG & PHOENIX & ARIZONA & 68 & 2.27 \\
\hline AIR FORCE & EWVRA SHEPHERD FIELD ANG & MARTINSBURG & WEST VIRGINIA & 68 & 2.27 \\
\hline AIR FORCE & ROBINS AIR FORCE BASE (ANG) & ROBINS AF BASE & GEORGIA & 69 & 2.30 \\
\hline ARMY & KENTUCKY ARNG & FRANKFORT & KENTUCKY & 71 & 2.37 \\
\hline NAVY & PMRF BARKING SANDS HI & KEKAHA & HAWAII & 71 & 2.37 \\
\hline AIR FORCE & $\begin{array}{l}\text { YOUNGSTOWN-WARREN } \\
\text { REGIONAL AIRPORT ARS }\end{array}$ & VIENNA & $\mathrm{OHIO}$ & 71 & 2.37 \\
\hline NRO & CAPE & PATRICK AFB & FLORIDA & 72 & 2.40 \\
\hline ARMY & FORT A P HILL & BOWLING GREEN & VIRGINIA & 72 & 2.40 \\
\hline NAVY & NAF EL CENTRO CA & EL CENTRO & CALIFORNIA & 74 & 2.47 \\
\hline ARMY & COLORADO ARNG & ENGLEWOOD & COLORADO & 75 & 2.50 \\
\hline AIR FORCE & MCGHEE TYSON AIRPORT & LOUISVILLE & TENNESSEE & 75 & 2.50 \\
\hline ARMY & MONTANA ARNG & HELENA & MONTANA & 76 & 2.54 \\
\hline ARMY & NEBRASKA ARNG & LINCOLN & NEBRASKA & 76 & 2.54 \\
\hline ARMY & FLORIDA ARNG & SAINT AUGUSTINE & FLORIDA & 77 & 2.57 \\
\hline AIR FORCE & $\begin{array}{l}\text { NIAGARA FALLS IAP-AIR RESERVE } \\
\text { STATION (AFR) }\end{array}$ & NIAGARA FALLS & NEW YORK & 78 & 2.60 \\
\hline NAVY & NSF BEAUFORT SC & BEAUFORT & SOUTH CAROLINA & 78 & 2.60 \\
\hline ARMY & USAG MIAMI & MIAMI & FLORIDA & 80 & 2.67 \\
\hline ARMY & WYOMING ARNG & CHYENNE & WYOMING & 81 & 2.70 \\
\hline ARMY & CONNECTICUT ARNG & HARTFORD & CONNECTICUT & 82 & 2.74 \\
\hline
\end{tabular}


Table A.1 (continued)

\begin{tabular}{|c|c|c|c|c|c|}
\hline Component & Installation Name & City & State / Country & $\begin{array}{c}\text { Total Site } \\
\text { Delivered } \\
\text { Energy } \\
\text { (BBTU) Goal } \\
\text { Subject } \\
\end{array}$ & $\begin{array}{c}\text { Annual } \\
\text { Average } \\
\text { Site Energy } \\
\text { (MWe) } \\
\end{array}$ \\
\hline ARMY & MARYLAND ARNG & BALTIMORE & MARYLAND & 83 & 2.77 \\
\hline NRO & ADF - SOUTHWEST & LAS CRUCES & NEW MEXICO & 85 & 2.84 \\
\hline AIR FORCE & GRISSOM AIR RESERVE BASE & KOKOMO & INDIANA & 86 & 2.87 \\
\hline AIR FORCE & DOBBINS AIR RESERVE BASE & MARIETTA & GEORGIA & 88 & 2.94 \\
\hline AIR FORCE & $\begin{array}{l}\text { STEWART INTERNATIONAL } \\
\text { AIRPORT }\end{array}$ & NEWBURGH & NEW YORK & 88 & 2.94 \\
\hline ARMY & UTAH ARNG & DRAPER & UTAH & 89 & 2.97 \\
\hline ARMY & DEVENS RFTA & DEVENS & MASSACHUSETTS & 91 & 3.04 \\
\hline ARMY & NEW YORK ARNG & LATHAM & NEW YORK & 93 & 3.10 \\
\hline NAVY & WPNSTA SEAL BEACH CA & SEAL BEACH & CALIFORNIA & 93 & 3.10 \\
\hline AIR FORCE & LOS ANGELES AIR FORCE BASE & EL SEGUNDO & CALIFORNIA & 94 & 3.14 \\
\hline AIR FORCE & RAF CROUGHTON & FPO & UNITED KINGDOM & 95 & 3.17 \\
\hline AIR FORCE & $\begin{array}{l}\text { PEASE INTERNATIONAL } \\
\text { TRADEPORT }\end{array}$ & PORTSMOUTH & NEW HAMPSHIRE & 96 & 3.20 \\
\hline NAVY & NAS WHITING FIELD MILTON FL & MILTON & FLORIDA & 97 & 3.24 \\
\hline ARMY & OREGON ARNG & SALEM & OREGON & 97 & 3.24 \\
\hline ARMY & IDAHO ARNG & BOISE & IDAHO & 101 & 3.37 \\
\hline ARMY & SOLDIER SYSTEMS CTR, & NATICK & MASSACHUSETTS & 103 & 3.44 \\
\hline DLA & $\begin{array}{l}\text { DEFENSE DISTRIBUTION DEPOT } \\
\text { SAN JOAQUIN }\end{array}$ & TRACY & CALIFORNIA & 104 & 3.47 \\
\hline ARMY & TOOELE ARMY DEPOT & TOOELE & UTAH & 105 & 3.50 \\
\hline NAVY & NAS KINGSVILLE TX & KINGSVILLE & TEXAS & 106 & 3.54 \\
\hline ARMY & BLUE GRASS ARMY DEPOT & RICHMOND & KENTUCKY & 107 & 3.57 \\
\hline WHS & FORT BELVOIR & FORT BELVOIR & VIRGINIA & 107 & 3.57 \\
\hline ARMY & OKLAHOMA ARNG & OKLAHOMA CITY & OKLAHOMA & 107 & 3.57 \\
\hline ARMY & KANSAS ARNG & TOPEKA & KANSAS & 108 & 3.60 \\
\hline
\end{tabular}


Table A.1 (continued)

\begin{tabular}{|c|c|c|c|c|c|}
\hline Component & Installation Name & City & State / Country & $\begin{array}{c}\text { Total Site } \\
\text { Delivered } \\
\text { Energy } \\
\text { (BBTU) Goal } \\
\text { Subject } \\
\end{array}$ & $\begin{array}{c}\text { Annual } \\
\text { Average } \\
\text { Site Energy } \\
\text { (MWe) } \\
\end{array}$ \\
\hline USMC & FIRST MCD GARDEN CITY LI NY & LONG ISLAND & NEW YORK & 113 & 3.77 \\
\hline ARMY & FORT BUCHANAN & FORT BUCHANAN & PUERTO RICO & 113 & 3.77 \\
\hline ARMY & GEORGIA ARNG & ATLANTA & GEORGIA & 115 & 3.84 \\
\hline USMC & $\begin{array}{l}\text { NAVAL HOSPITAL CAMP } \\
\text { PENDLETON CA }\end{array}$ & CAMP PENDLETON & CALIFORNIA & 115 & 3.84 \\
\hline ARMY & NEW JERSEY ARNG & LAWRENCEVILLE & NEW JERSEY & 116 & 3.87 \\
\hline ARMY & SOUTH CAROLINA ARNG & COLUMBIA & SOUTH CAROLINA & 117 & 3.90 \\
\hline AIR FORCE & BUCKLEY AIR FORCE BASE (ANG) & AURORA & COLORADO & 120 & 4.00 \\
\hline AIR FORCE & MARCH AIR RESERVE BASE (AFR) & RIVERSIDE & CALIFORNIA & 120 & 4.00 \\
\hline AIR FORCE & LAUGHLIN AIR FORCE BASE & DEL RIO & TEXAS & 122 & 4.07 \\
\hline AIR FORCE & VANCE AIR FORCE BASE & ENID & OKLAHOMA & 123 & 4.10 \\
\hline ARMY & CARLISLE BARRACKS & CARLISLE & PENNSYLVANIA & 124 & 4.14 \\
\hline ARMY & TENNESSEE ARNG & NASHVILLE & TENNESSEE & 125 & 4.17 \\
\hline USMC & MCAS FUTENMA JA & FPO & JAPAN & 126 & 4.20 \\
\hline ARMY & NORTH DAKOTA ARNG & BISMARK & NORTH DAKOTA & 126 & 4.20 \\
\hline ARMY & USAG BENELUX & FPO & BELGIUM & 126 & 4.20 \\
\hline NAVY & CBC GULFPORT MS & GULFPORT & MISSISSIPPI & 130 & 4.34 \\
\hline USMC & MARFORRES NEW ORLEANS LA & NEW ORLEANS & LOUISIANA & 131 & 4.37 \\
\hline ARMY & MISSOURI ARNG & JEFFERSON CITY & MISSOURI & 133 & 4.44 \\
\hline NAVY & NAVSTA EVERETT WA & EVERETT & WASHINGTON & 133 & 4.44 \\
\hline ARMY & NORTH CAROLINA ARNG & RALEIGH & NORTH CAROLINA & 133 & 4.44 \\
\hline AIR FORCE & COLUMBUS AIR FORCE BASE & COLUMBUS & MISSISSIPPI & 135 & 4.50 \\
\hline NAVY & NSA PANAMA CITY FL & $\begin{array}{l}\text { PANAMA CITY } \\
\text { BEACH }\end{array}$ & FLORIDA & 136 & 4.54 \\
\hline USMC & $\begin{array}{l}\text { NAVAL HOSPITAL CAMP LEJEUNE } \\
\text { NC }\end{array}$ & CAMP LEJEUNE & NORTH CAROLINA & 137 & 4.57 \\
\hline
\end{tabular}


Table A.1 (continued)

\begin{tabular}{|c|c|c|c|c|c|}
\hline Component & Installation Name & City & State / Country & $\begin{array}{c}\text { Total Site } \\
\text { Delivered } \\
\text { Energy } \\
\text { (BBTU) Goal } \\
\text { Subject } \\
\end{array}$ & $\begin{array}{c}\text { Annual } \\
\text { Average } \\
\text { Site Energy } \\
\text { (MWe) } \\
\end{array}$ \\
\hline NAVY & WPNSTA EARLE COLTS NECK NJ & COLTS NECK & NEW JERSEY & 139 & 4.64 \\
\hline ARMY & YUMA PROVING GROUND & YUMA & ARIZONA & 143 & 4.77 \\
\hline NAVY & NSA MONTEREY CA & MONTEREY & CALIFORNIA & 144 & 4.80 \\
\hline ARMY & ILLINOIS ARNG & CAMP LINCOLN & ILLINOIS & 145 & 4.84 \\
\hline ARMY & SIERRA ARMY DEPOT & HERLONG & CALIFORNIA & 147 & 4.90 \\
\hline ARMY & IOWA ARNG & JOHNSTON & IOWA & 149 & 4.97 \\
\hline AIR FORCE & RAF ALCONBURY & FPO & UNITED KINGDOM & 149 & 4.97 \\
\hline ARMY & OHIO ARNG & COLUMBUS & $\mathrm{OHIO}$ & 151 & 5.04 \\
\hline ARMY & TEXAS ARNG & CAMP MABRY & TEXAS & 151 & 5.04 \\
\hline ARMY & LOUISIANA ARNG & $\begin{array}{l}\text { JOHNSON } \\
\text { BARRACKS }\end{array}$ & LOUISIANA & 152 & 5.07 \\
\hline ARMY & MASSACHUSETTS ARNG & MILFORD & MASSACHUSETTS & 152 & 5.07 \\
\hline AIR FORCE & WESTOVER AIR RESERVE BASE & CHICOPEE & MASSACHUSETTS & 154 & 5.14 \\
\hline USMC & NAVAL HOSPITAL OKINAWA JA & FPO & JAPAN & 155 & 5.17 \\
\hline ARMY & HAWTHORNE AAP (GOCO) & HAWTHORNE & NEVADA & 158 & 5.27 \\
\hline NAVY & NAS MERIDIAN MS & MERIDIAN & MISSISSIPPI & 158 & 5.27 \\
\hline AIR FORCE & SELFRIDGE ANG BASE & MOUNT CLEMENS & MICHIGAN & 165 & 5.51 \\
\hline ARMY & ALABAMA ARNG & MONTGOMERY & ALABAMA & 166 & 5.54 \\
\hline NAVY & NAS JRB NEW ORLEANS LA & NEW ORLEANS & LOUISIANA & 170 & 5.67 \\
\hline AIR FORCE & $\begin{array}{l}\text { BUCKLEY AIR FORCE BASE } \\
\text { (AFSPC) }\end{array}$ & AURORA & COLORADO & 171 & 5.71 \\
\hline ARMY & VIRGINIA ARNG & FORT PICKETT & VIRGINIA & 171 & 5.71 \\
\hline ARMY & WISCONSIN ARNG & MADISON & WISCONSIN & 179 & 5.97 \\
\hline ARMY & PRESIDIO OF MONTEREY & MONTEREY & CALIFORNIA & 180 & 6.01 \\
\hline NRO & WESTFIELDS & CHANTILLY & VIRGINIA & 182 & 6.07 \\
\hline ARMY & ADELPHI LABORATORY CTR & HYATTSVILLE & MARYLAND & 184 & 6.14 \\
\hline
\end{tabular}


Table A.1 (continued)

\begin{tabular}{|c|c|c|c|c|c|}
\hline Component & Installation Name & City & State / Country & $\begin{array}{c}\text { Total Site } \\
\text { Delivered } \\
\text { Energy } \\
\text { (BBTU) Goal } \\
\text { Subject } \\
\end{array}$ & $\begin{array}{c}\text { Annual } \\
\text { Average } \\
\text { Site Energy } \\
\text { (MWe) } \\
\end{array}$ \\
\hline USMC & MCAS BEAUFORT SC & BEAUFORT & SOUTH CAROLINA & 192 & 6.41 \\
\hline NAVY & WPNSTA YORKTOWN VA & YORKTOWN & VIRGINIA & 194 & 6.47 \\
\hline ARMY & CALIFORNIA ARNG & SACRAMENTO & CALIFORNIA & 195 & 6.51 \\
\hline ARMY & WEST VIRGINIA ARNG & CHARLESTON & WEST VIRGINIA & 197 & 6.57 \\
\hline NAVY & NAVSTA ROTA SP & FPO & SPAIN & 204 & 6.81 \\
\hline NAVY & NAS FALLON NV & FALLON & NEVADA & 207 & 6.91 \\
\hline USMC & MCAS YUMA AZ & YUMA & ARIZONA & 210 & 7.01 \\
\hline AIR FORCE & MOODY AIR FORCE BASE & MOODY AF BASE & GEORGIA & 211 & 7.04 \\
\hline NAVY & NAVSTA MAYPORT FL & JACKSONVILLE & JAPAN & 212 & 7.07 \\
\hline NAVY & NAS SIGONELLA IT & FPO & ITALY & 213 & 7.11 \\
\hline NAVY & NSA MID SOUTH MILLINGTON TN & MILLINGTON & TENNESSEE & 217 & 7.24 \\
\hline ARMY & ARKANSAS ARNG & CAMP ROBINSON & ARKANSAS & 221 & 7.37 \\
\hline AIR FORCE & GOODFELLOW AIR FORCE BASE & SAN ANGELO & TEXAS & 221 & 7.37 \\
\hline NAVY & NAS CORPUS CHRISTI TX & CORPUS CHRISTI & TEXAS & 224 & 7.47 \\
\hline ARMY & MISSISSIPPI ARNG & JACKSON & MISSISSIPPI & 230 & 7.67 \\
\hline ARMY & $\begin{array}{l}\text { 63RD REGIONAL SUPPORT } \\
\text { COMMAND }\end{array}$ & MOFFETT FIELD & CALIFORNIA & 231 & 7.71 \\
\hline AIR FORCE & GRAND FORKS AIR FORCE BASE & GRAND FORKS AFB & NORTH DAKOTA & 232 & 7.74 \\
\hline DLA & $\begin{array}{l}\text { DEFENSE SUPPLY CENTER } \\
\text { RICHMOND }\end{array}$ & RICHMOND & VIRGINIA & 235 & 7.84 \\
\hline ARMY & MINNESOTA ARNG & CAMP RIPLEY & MINNESOTA & 245 & 8.17 \\
\hline AIR FORCE & RAF MILDENHALL & FPO & UNITED KINGDOM & 246 & 8.21 \\
\hline NAVY & NAS LEMOORE CA & LEMOORE & CALIFORNIA & 247 & 8.24 \\
\hline ARMY & FORT GREELY & DELTA JUNCTION & ALASKA & 248 & 8.27 \\
\hline AIR FORCE & $\begin{array}{l}\text { MCCONNELL AIR FORCE BASE } \\
\text { (AMC) }\end{array}$ & WICHITA & KANSAS & 250 & 8.34 \\
\hline
\end{tabular}


Table A.1 (continued)

\begin{tabular}{|c|c|c|c|c|c|}
\hline Component & Installation Name & City & State / Country & $\begin{array}{c}\text { Total Site } \\
\text { Delivered } \\
\text { Energy } \\
\text { (BBTU) Goal } \\
\text { Subject } \\
\end{array}$ & $\begin{array}{c}\text { Annual } \\
\text { Average } \\
\text { Site Energy } \\
\text { (MWe) }\end{array}$ \\
\hline NAVY & NAS JRB FORT WORTH TX & FORT WORTH & TEXAS & 253 & 8.44 \\
\hline NAVY & NSA BAHRAIN & FPO & BAHRAIN & 253 & 8.44 \\
\hline ARMY & $\begin{array}{l}\text { 81ST REGIONAL SUPPORT } \\
\text { COMMAND }\end{array}$ & FORT JACKSON & SOUTH CAROLINA & 255 & 8.51 \\
\hline AIR FORCE & ALTUS AIR FORCE BASE & ALTUS & OKLAHOMA & 255 & 8.51 \\
\hline USMC & MCLB BARSTOW CA & BARSTOW & CALIFORNIA & 257 & 8.57 \\
\hline ARMY & DUGWAY PROVING GROUND & DUGWAY & UTAH & 262 & 8.74 \\
\hline USMC & MCAS MIRAMAR CA & SAN DIEGO & CALIFORNIA & 263 & 8.77 \\
\hline ARMY & USAG DETROIT ARSENAL & $\begin{array}{l}\text { HARRISON } \\
\text { TOWNSHIP }\end{array}$ & MICHIGAN & 264 & 8.81 \\
\hline ARMY & PINE BLUFF ARSENAL & WHITE HALL & ARKANSAS & 266 & 8.87 \\
\hline USMC & CG MCLB ALBANY GA & ALBANY & GEORGIA & 269 & 8.97 \\
\hline USMC & MARCORCRUITDEP SAN DIEGO CA & SAN DIEGO & CALIFORNIA & 269 & 8.97 \\
\hline ARMY & USAG ANSBACH & FPO & GERMANY & 273 & 9.11 \\
\hline ARMY & SCRANTON AAP & SCRANTON & PENNSYLVANIA & 275 & 9.18 \\
\hline DLA & DLA LAND AND MARITIME & COLUMBUS & $\mathrm{OHIO}$ & 277 & 9.24 \\
\hline NAVY & CFA SASEBO JA & FPO & JAPAN & 280 & 9.34 \\
\hline AIR FORCE & LUKE AIR FORCE BASE & GLENDALE & ARIZONA & 281 & 9.38 \\
\hline AIR FORCE & AVIANO AIR BASE & FPO & ITALY & 286 & 9.54 \\
\hline AIR FORCE & SHAW AIR FORCE BASE & SHAW AF BASE & SOUTH CAROLINA & 291 & 9.71 \\
\hline ARMY & WATERVLIET ARSENAL & WATERVLIET & NEW YORK & 292 & 9.74 \\
\hline ARMY & WHITE SANDS MISSILE RANGE & WHITE SANDS & NEW MEXICO & 293 & 9.78 \\
\hline AIR FORCE & $\begin{array}{l}\text { SEYMOUR JOHNSON AIR FORCE } \\
\text { BASE }\end{array}$ & $\begin{array}{l}\text { SEYMOUR JOHNSON } \\
\text { AFB }\end{array}$ & NORTH CAROLINA & 297 & 9.91 \\
\hline AIR FORCE & DYESS AIR FORCE BASE & ABILENE & TEXAS & 300 & 10.01 \\
\hline AIR FORCE & INCIRLIK AIR BASE ADANA & FPO & TURKEY & 305 & 10.18 \\
\hline
\end{tabular}


Table A.1 (continued)

\begin{tabular}{|c|c|c|c|c|c|}
\hline Component & Installation Name & City & State / Country & $\begin{array}{c}\text { Total Site } \\
\text { Delivered } \\
\text { Energy } \\
\text { (BBTU) Goal } \\
\text { Subject } \\
\end{array}$ & $\begin{array}{c}\text { Annual } \\
\text { Average } \\
\text { Site Energy } \\
\text { (MWe) }\end{array}$ \\
\hline AIR FORCE & $\begin{array}{l}\text { MOUNTAIN HOME AIR FORCE } \\
\text { BASE }\end{array}$ & ELMORE & IDAHO & 305 & 10.18 \\
\hline ARMY & PENNSYLVANIA ARNG & ANNVILLE & PENNSYLVANIA & 306 & 10.21 \\
\hline USMC & MCB HAWAII KANEOHE BAY HI & KANEOHE BAY & HAWAII & 315 & 10.51 \\
\hline NAVY & NAS KEY WEST FL & KEY WEST & FLORIDA & 317 & 10.58 \\
\hline AIR FORCE & BEALE AIR FORCE BASE & BEALE AFB & CALIFORNIA & 318 & 10.61 \\
\hline ARMY & INDIANA ARNG & INDIANOPOLIS & INDIANA & 318 & 10.61 \\
\hline DLA & $\begin{array}{l}\text { DEFENSE DISTRIBUTION CENTER, } \\
\text { SUSQUEHANNA }\end{array}$ & NEW CUMBERLAND & PENNSYLVANIA & 323 & 10.78 \\
\hline AIR FORCE & $\begin{array}{l}\text { FRANCIS E WARREN AIR FORCE } \\
\text { BASE }\end{array}$ & CHEYENNE & WYOMING & 324 & 10.81 \\
\hline ARMY & JOINT BASE MYER-HENDERSON & FORT MYER & VIRGINIA & 326 & 10.88 \\
\hline AIR FORCE & KUNSAN AIR BASE & FPO & $\begin{array}{l}\text { KOREA, REPUBLIC } \\
\text { OF }\end{array}$ & 329 & 10.98 \\
\hline ARMY & $\begin{array}{l}\text { 99TH REGIONAL SUPPORT } \\
\text { COMMAND }\end{array}$ & JOINT BASE MDL & NEW JERSEY & 331 & 11.04 \\
\hline ARMY & FORT MCCOY & SPARTA & WISCONSIN & 334 & 11.14 \\
\hline AIR FORCE & $\begin{array}{l}\text { DAVIS-MONTHAN AIR FORCE } \\
\text { BASE }\end{array}$ & TUCSON & ARIZONA & 342 & 11.41 \\
\hline ARMY & CORPUS CHRISTI AD & CORPUS CHRISTI & TEXAS & 343 & 11.44 \\
\hline ARMY & MICHIGAN ARNG & LANSING & MICHIGAN & 360 & 12.01 \\
\hline AIR FORCE & TYNDALL AIR FORCE BASE & $\begin{array}{l}\text { PANAMA CITY } \\
\text { BEACH }\end{array}$ & FLORIDA & 360 & 12.01 \\
\hline NAVY & $\begin{array}{l}\text { NAVBASE VENTURA CTY PT } \\
\text { MUGU } \\
\text { CA }\end{array}$ & POINT MUGU & CALIFORNIA & 362 & 12.08 \\
\hline AIR FORCE & CANNON AIR FORCE BASE & CANNON AFB & NEW MEXICO & 363 & 12.11 \\
\hline
\end{tabular}


Table A.1 (continued)

\begin{tabular}{|c|c|c|c|c|c|}
\hline Component & Installation Name & City & State / Country & $\begin{array}{c}\text { Total Site } \\
\text { Delivered } \\
\text { Energy } \\
\text { (BBTU) Goal } \\
\text { Subject } \\
\end{array}$ & $\begin{array}{c}\text { Annual } \\
\text { Average } \\
\text { Site Energy } \\
\text { (MWe) }\end{array}$ \\
\hline ARMY & FORT LEAVENWORTH & $\begin{array}{l}\text { FORT } \\
\text { LEAVENWORTH }\end{array}$ & KANSAS & 375 & 12.51 \\
\hline NAVY & NSA ANDERSEN GUAM & FPO & GUAM & 376 & 12.54 \\
\hline ARMY & FORT IRWIN & FORT IRWIN & CALIFORNIA & 379 & 12.65 \\
\hline AIR FORCE & SPANGDAHLEM AIR BASE & FPO & GERMANY & 382 & 12.75 \\
\hline NAVY & NSA NAPLES IT & FPO & ITALY & 386 & 12.88 \\
\hline NRO & ADF - EAST & FORT BELVIOR & VIRGINIA & 391 & 13.05 \\
\hline AIR FORCE & LITTLE ROCK AIR FORCE BASE & LITTLE ROCK & ARKANSAS & 393 & 13.11 \\
\hline AIR FORCE & $\begin{array}{l}\text { FAIRCHILD AIR FORCE BASE } \\
\text { (AMC) }\end{array}$ & AIRWAY HEIGHTS & WASHINGTON & 394 & 13.15 \\
\hline AIR FORCE & MALMSTROM AIR FORCE BASE & MALMSTROM AFB & MONTANA & 395 & 13.18 \\
\hline ARMY & LETTERKENNY ARMY DEPOT & CHAMBERSBURG & PENNSYLVANIA & 401 & 13.38 \\
\hline NAVY & NAS WHIDBEY ISLAND WA & OAK HARBOR & WASHINGTON & 401 & 13.38 \\
\hline AIR FORCE & DOVER AIR FORCE BASE & DOVER & DELAWARE & 405 & 13.51 \\
\hline ARMY & TOBYHANNA ARMY DEPOT & TOBYHANNA & PENNSYLVANIA & 409 & 13.65 \\
\hline NAVY & JBAB WASHINGTON DC & $\begin{array}{l}\text { JOINT BASE } \\
\text { ANACOSTIA } \\
\text { BOLLING } \\
\end{array}$ & $\begin{array}{l}\text { DISTRICT OF } \\
\text { COLUMBIA }\end{array}$ & 414 & 13.81 \\
\hline NAVY & NAVBASE POINT LOMA CA & SAN DIEGO & CALIFORNIA & 415 & 13.85 \\
\hline AIR FORCE & ELLSWORTH AIR FORCE BASE & ELLSWORTH AFB & SOUTH DAKOTA & 417 & 13.91 \\
\hline NAVY & $\begin{array}{l}\text { NSS NORFOLK NAVAL SHIPYARD } \\
\text { VA }\end{array}$ & NORFOLK & VIRGINIA & 422 & 14.08 \\
\hline ARMY & LIMA JSMC & LIMA & $\mathrm{OHIO}$ & 429 & 14.31 \\
\hline ARMY & USAG DAEGU & FPO & $\begin{array}{l}\text { KOREA, REPUBLIC } \\
\text { OF }\end{array}$ & 445 & 14.85 \\
\hline ARMY & FORT HUACHUCA & FORT HUACHUCA & ARIZONA & 447 & 14.91 \\
\hline
\end{tabular}


Table A.1 (continued)

\begin{tabular}{|c|c|c|c|c|c|}
\hline Component & Installation Name & City & State / Country & $\begin{array}{c}\text { Total Site } \\
\text { Delivered } \\
\text { Energy } \\
\text { (BBTU) Goal } \\
\text { Subject } \\
\end{array}$ & $\begin{array}{c}\text { Annual } \\
\text { Average } \\
\text { Site Energy } \\
\text { (MWe) }\end{array}$ \\
\hline AIR FORCE & SCHRIEVER AIR FORCE BASE & $\begin{array}{l}\text { COLORADO } \\
\text { SPRINGS }\end{array}$ & COLORADO & 447 & 14.91 \\
\hline ARMY & MCALESTER AAP & MCALESTER & OKLAHOMA & 451 & 15.05 \\
\hline AIR FORCE & BARKSDALE AIR FORCE BASE & $\begin{array}{l}\text { BARKSDALE AF } \\
\text { BASE }\end{array}$ & LOUISIANA & 469 & 15.65 \\
\hline AIR FORCE & TRAVIS AIR FORCE BASE & FAIRFIELD & CALIFORNIA & 477 & 15.91 \\
\hline USMC & $\begin{array}{l}\text { MARCORCRUITDEP PARRIS } \\
\text { ISLAND } \\
\text { SC }\end{array}$ & PARRIS ISLAND & SOUTH CAROLINA & 479 & 15.98 \\
\hline AIR FORCE & HANSCOM AIR FORCE BASE & BEDFORD & MASSACHUSETTS & 484 & 16.15 \\
\hline AIR FORCE & WHITEMAN AIR FORCE BASE & KNOB NOSTER & MISSOURI & 487 & 16.25 \\
\hline ARMY & PICATINNY ARSENAL & DOVER & NEW JERSEY & 492 & 16.42 \\
\hline NAVY & NAF ATSUGI JA & FPO & JAPAN & 501 & 16.72 \\
\hline AIR FORCE & HURLBURT FIELD & EGLIN AFB & FLORIDA & 509 & 16.98 \\
\hline ARMY & FORT RUCKER & FORT RUCKER & ALABAMA & 513 & 17.12 \\
\hline ARMY & $\begin{array}{l}\text { 88TH REGIONAL } \\
\text { SUPPORTCOMMAND }\end{array}$ & FORT MCCOY & WISCONSIN & 523 & 17.45 \\
\hline AIR FORCE & SCOTT AIR FORCE BASE (AMC) & BELLEVILLE & ILLINOIS & 531 & 17.72 \\
\hline NAVY & NAVBASE GUAM & FPO & GUAM & 534 & 17.82 \\
\hline AIR FORCE & MACDILL AIR FORCE BASE & TAMPA & FLORIDA & 537 & 17.92 \\
\hline AIR FORCE & HOLLOMAN AIR FORCE BASE & ALAMOGORDO & NEW MEXICO & 545 & 18.18 \\
\hline ARMY & ROCK ISLAND ARSENAL & ROCK ISLAND & ILLINOIS & 545 & 18.18 \\
\hline AIR FORCE & VANDENBERG AIR FORCE BASE & LOMPOC & CALIFORNIA & 554 & 18.48 \\
\hline AIR FORCE & MINOT AIR FORCE BASE & MINOT AFB & NORTH DAKOTA & 578 & 19.28 \\
\hline AIR FORCE & $\begin{array}{l}\text { JOINT BASE ANDREWS-NAVAL AIR } \\
\text { FACILITY WASHINGTON }\end{array}$ & ANDREWS AFB & MARYLAND & 580 & 19.35 \\
\hline NAVY & NSA BETHESDA MD & BETHESDA & MARYLAND & 580 & 19.35 \\
\hline
\end{tabular}


Table A.1 (continued)

\begin{tabular}{|c|c|c|c|c|c|}
\hline Component & Installation Name & City & State / Country & $\begin{array}{c}\text { Total Site } \\
\text { Delivered } \\
\text { Energy } \\
\text { (BBTU) Goal } \\
\text { Subject } \\
\end{array}$ & $\begin{array}{c}\text { Annual } \\
\text { Average } \\
\text { Site Energy } \\
\text { (MWe) }\end{array}$ \\
\hline AIR FORCE & RAF LAKENHEATH & FPO & UNITED KINGDOM & 582 & 19.42 \\
\hline AIR FORCE & SHEPPARD AIR FORCE BASE & WICHITA FALLS & TEXAS & 603 & 20.12 \\
\hline NAVY & NAVSTA NEWPORT RI & NEWPORT & RHODE ISLAND & 613 & 20.45 \\
\hline NAVY & NAWS CHINA LAKE CA & CHINA LAKE & CALIFORNIA & 613 & 20.45 \\
\hline ARMY & FORT DRUM & FORT DRUM & NEW YORK & 619 & 20.65 \\
\hline ARMY & FORT GEORGE MEADE & FORT MEADE & MARYLAND & 620 & 20.69 \\
\hline ARMY & USAG VICENZA & FPO & ITALY & 629 & 20.99 \\
\hline NAVY & $\begin{array}{l}\text { JEB LITTLE CREEK-FORT STORY } \\
\text { VA }\end{array}$ & VIRGINIA BEACH & VIRGINIA & 632 & 21.09 \\
\hline ARMY & USAG STUTTGART & FPO & GERMANY & 632 & 21.09 \\
\hline AIR FORCE & KEESLER AIR FORCE BASE & BILOXI & MISSISSIPPI & 638 & 21.29 \\
\hline AIR FORCE & MAXWELL AIR FORCE BASE & MONTGOMERY & ALABAMA & 643 & 21.45 \\
\hline AIR FORCE & OSAN AIR BASE & OSAN AFB & $\begin{array}{l}\text { KOREA, REPUBLIC } \\
\text { OF }\end{array}$ & 646 & 21.55 \\
\hline ARMY & USAG WIESBADEN & FPO & GERMANY & 650 & 21.69 \\
\hline ARMY & CAMP ZAMA JAPAN & FPO & JAPAN & 656 & 21.89 \\
\hline USMC & MCAS IWAKUNI JA & FPO & JAPAN & 670 & 22.35 \\
\hline NAVY & SUBASE NEW LONDON CT & GROTON & CONNECTICUT & 674 & 22.49 \\
\hline NAVY & NAS OCEANA VA & VIRGINIA BEACH & VIRGINIA & 681 & 22.72 \\
\hline NAVY & SUBASE KINGS BAY GA & KINGS BAY & GEORGIA & 685 & 22.85 \\
\hline USMC & MCAS CHERRY PT NC & CHERRY POINT & NORTH CAROLINA & 688 & 22.95 \\
\hline AIR FORCE & EARECKSON AIR STATION & ADAK STATION & ALASKA & 696 & 23.22 \\
\hline ARMY & IOWA AAP (GOCO) & MIDDLETOWN & IOWA & 705 & 23.52 \\
\hline ARMY & ANNISTON ARMY DEPOT & ANNISTON & ALABAMA & 707 & 23.59 \\
\hline NGA & NGA & SPRINGFIELD & VIRGINIA & 717 & 23.92 \\
\hline NAVY & NSA MECHANICSBURG PA & MECHANICSBURG & PENNSYLVANIA & 732 & 24.42 \\
\hline
\end{tabular}


Table A.1 (continued)

\begin{tabular}{|c|c|c|c|c|c|}
\hline Component & Installation Name & City & State / Country & $\begin{array}{c}\text { Total Site } \\
\text { Delivered } \\
\text { Energy } \\
\text { (BBTU) Goal } \\
\text { Subject } \\
\end{array}$ & $\begin{array}{c}\text { Annual } \\
\text { Average } \\
\text { Site Energy } \\
\text { (MWe) }\end{array}$ \\
\hline ARMY & FORT POLK & FORT POLK & LOUISIANA & 736 & 24.56 \\
\hline NAVY & NSA ANNAPOLIS MD & ANNAPOLIS & MARYLAND & 739 & 24.66 \\
\hline ARMY & RED RIVER DEPOT & TEXARKANA & TEXAS & 744 & 24.82 \\
\hline AIR FORCE & OFFUTT AIR FORCE BASE & OFFUTT A.F.B. & NEBRASKA & 745 & 24.86 \\
\hline NAVY & FRC EAST CHERRY POINT NC & CHERRY POINT & NORTH CAROLINA & 746 & 24.89 \\
\hline ARMY & FORT LEE & FORT LEE & VIRGINIA & 747 & 24.92 \\
\hline AIR FORCE & CHARLESTON AIR FORCE BASE & CHARLESTON & SOUTH CAROLINA & 748 & 24.96 \\
\hline AIR FORCE & EDWARDS AIR FORCE BASE & LANCASTER & CALIFORNIA & 782 & 26.09 \\
\hline AIR FORCE & PATRICK AIR FORCE BASE & PATRICK AFB & FLORIDA & 782 & 26.09 \\
\hline ARMY & USAG HUMPHREYS & FPO & $\begin{array}{l}\text { KOREA, REPUBLIC } \\
\text { OF }\end{array}$ & 786 & 26.22 \\
\hline ARMY & KWAJALEIN ATOLL & FPO & $\begin{array}{l}\text { MARSHALL } \\
\text { ISLANDS }\end{array}$ & 826 & 27.56 \\
\hline AIR FORCE & KIRTLAND AIR FORCE BASE & ALBUQUERQUE & NEW MEXICO & 827 & 27.59 \\
\hline ARMY & USAG HAWAII & WAHIAWA & HAWAII & 830 & 27.69 \\
\hline ARMY & FORT GORDON & AUGUSTA & GEORGIA & 850 & 28.36 \\
\hline ARMY & WEST POINT MIL RESERVATION & WEST POINT & NEW YORK & 854 & 28.49 \\
\hline ARMY & FORT DETRICK & FORT DETRICK & MARYLAND & 866 & 28.89 \\
\hline NAVY & CAMP LEMONNIER DJBOUTI & FPO & DJBOUTI & 871 & 29.06 \\
\hline ARMY & FORT JACKSON & COLUMBIA & SOUTH CAROLINA & 879 & 29.33 \\
\hline AIR FORCE & USAF ACADEMY & $\begin{array}{l}\text { AIR FORCE } \\
\text { ACADEMY }\end{array}$ & COLORADO & 887 & 29.59 \\
\hline AIR FORCE & NELLIS AIR FORCE BASE & LAS VEGAS & NEVADA & 895 & 29.86 \\
\hline ARMY & USAG YONGSAN & FPO & SOUTH KOREA & 901 & 30.06 \\
\hline USMC & CG MCCDC QUANTICO VA & QUANTICO & VIRGINIA & 902 & 30.09 \\
\hline
\end{tabular}


Table A.1 (continued)

\begin{tabular}{|c|c|c|c|c|c|}
\hline Component & Installation Name & City & State / Country & $\begin{array}{c}\text { Total Site } \\
\text { Delivered } \\
\text { Energy } \\
\text { (BBTU) Goal } \\
\text { Subject } \\
\end{array}$ & $\begin{array}{c}\text { Annual } \\
\text { Average } \\
\text { Site Energy } \\
\text { (MWe) } \\
\end{array}$ \\
\hline ARMY & USAG RED CLOUD & FPO & $\begin{array}{l}\text { KOREA, REPUBLIC } \\
\text { OF }\end{array}$ & 916 & 30.56 \\
\hline NAVY & NAS JACKSONVILLE FL & JACKSONVILLE & FLORIDA & 921 & 30.73 \\
\hline NAVY & NAS PATUXENT RIVER MD & PATUXENT RIVER & MARYLAND & 936 & 31.23 \\
\hline NAVY & NSF DIEGO GARCIA & FPO & INDIAN OCEAN & 950 & 31.70 \\
\hline ARMY & LAKE CITY AAP (GOCO) & INDEPENDENCE & MISSOURI & 955 & 31.86 \\
\hline NAVY & NSA HAMPTON ROADS VA & NORFOLK & VIRGINIA & 957 & 31.93 \\
\hline ARMY & FORT KNOX & FORT KNOX & KENTUCKY & 984 & 32.83 \\
\hline ARMY & FORT STEWART & FORT STEWART & GEORGIA & 989 & 33.00 \\
\hline USMC & CG MCB CAMP BUTLER JA & FPO & JAPAN & 1,000 & 33.36 \\
\hline USMC & CG MCB CAMP PENDLETON CA & CAMP PENDLETON & CALIFORNIA & 1,004 & 33.50 \\
\hline NAVY & NAVSTA GREAT LAKES IL & GREAT LAKES & CALIFORNIA & 1,004 & 33.50 \\
\hline NAVY & NSA CRANE IN & CRANE & INDIANA & 1,008 & 33.63 \\
\hline USMC & $\begin{array}{l}\text { CG MCAGCC TWENTYNINE PALMS } \\
\text { CA }\end{array}$ & $\begin{array}{l}\text { TWENTYNINE } \\
\text { PALMS }\end{array}$ & CALIFORNIA & 1,018 & 33.96 \\
\hline AIR FORCE & RAMSTEIN AIR BASE & FPO & GERMANY & 1,050 & 35.03 \\
\hline NAVY & NAS PENSACOLA FL & PENSACOLA & FLORIDA & 1,056 & 35.23 \\
\hline ARMY & FORT RILEY & FORT RILEY & KANSAS & 1,065 & 35.53 \\
\hline NAVY & NAVBASE SAN DIEGO CA & SAN DIEGO & CALIFORNIA & 1,065 & 35.53 \\
\hline NAVY & NSY BOS PORTSMOUTH NH & PORTSMOUTH & NEW HAMPSHIRE & 1,068 & 35.63 \\
\hline WHS & WASHINGTON HQS SERVICE & ARLINGTON & VIRGINIA & 1,081 & 36.07 \\
\hline NAVY & NAVSTA GUANTANAMO BAY CU & FPO & CUBA & 1,108 & 36.97 \\
\hline NAVY & JB PEARL HARBOR-HICKAM HI & PEARL HARBOR & HAWAII & 1,121 & 37.40 \\
\hline AIR FORCE & YOKOTA AIR BASE & FPO & JAPAN & 1,137 & 37.94 \\
\hline AIR FORCE & MCGUIRE AIR FORCE BASE (AMC) & MCGUIRE AFB & NEW JERSEY & 1,142 & 38.10 \\
\hline ARMY & FORT BELVOIR & FORT BELVOIR & VIRGINIA & 1,153 & 38.47 \\
\hline
\end{tabular}


Table A.1 (continued)

\begin{tabular}{|c|c|c|c|c|c|}
\hline Component & Installation Name & City & State / Country & $\begin{array}{c}\text { Total Site } \\
\text { Delivered } \\
\text { Energy } \\
\text { (BBTU) Goal } \\
\text { Subject } \\
\end{array}$ & $\begin{array}{c}\text { Annual } \\
\text { Average } \\
\text { Site Energy } \\
\text { (MWe) } \\
\end{array}$ \\
\hline AIR FORCE & LANGLEY AIR FORCE BASE & LANGLEY AFB & VIRGINIA & 1,168 & 38.97 \\
\hline ARMY & FORT SILL & FORT SILL & OKLAHOMA & 1,186 & 39.57 \\
\hline AIR FORCE & EGLIN AIR FORCE BASE & EGLIN AFB & FLORIDA & 1,203 & 40.14 \\
\hline AIR FORCE & KADENA AIR BASE & $\begin{array}{l}\text { KADENA AIR BASE } \\
\text { OKINAWA }\end{array}$ & JAPAN & 1,224 & 40.84 \\
\hline AIR FORCE & MISAWA AIR BASE & FPO & JAPAN & 1,225 & 40.87 \\
\hline ARMY & USAG RHEINLAND-PFALZ & FPO & GERMANY & 1,227 & 40.94 \\
\hline NAVY & $\begin{array}{l}\text { NAVBASE CORONADO SAN DIEGO } \\
\text { CA }\end{array}$ & SAN DIEGO & CALIFORNIA & 1,250 & 41.71 \\
\hline ARMY & FORT CARSON & COLORADO SPGS & COLORADO & 1,351 & 45.08 \\
\hline ARMY & FORT BLISS & EL PASO & TEXAS & 1,409 & 47.01 \\
\hline AIR FORCE & $\begin{array}{l}\text { JOINT BASE ELMENDORF-FT } \\
\text { RICHARDSON }\end{array}$ & ELMENDORF AFB & ALASKA & 1,440 & 48.04 \\
\hline ARMY & USAG BAVARIA & FPO & GERMANY & 1,475 & 49.21 \\
\hline ARMY & FORT BENNING & FORT BENNING & GEORGIA & 1,477 & 49.28 \\
\hline ARMY & FORT CAMPBELL & FORT CAMPBELL & KENTUCKY & 1,518 & 50.65 \\
\hline ARMY & FORT LEONARD WOOD & $\begin{array}{l}\text { FORT LEONARD } \\
\text { WOOD }\end{array}$ & MISSOURI & 1,525 & 50.88 \\
\hline ARMY & REDSTONE ARSENAL & HUNTSVILLE & ALABAMA & 1,557 & 51.95 \\
\hline NAVY & $\begin{array}{l}\text { NSA SOUTH POTOMAC DAHLGREN } \\
\text { VA }\end{array}$ & DAHLGREN & VIR & 1,676 & 55.92 \\
\hline AIR FORCE & ARNOLD AIR STATION & $\begin{array}{l}\text { ARNOLD A F } \\
\text { STATION }\end{array}$ & TENNESSEE & 1,695 & 56.55 \\
\hline NAVY & NSA WASHINGTON DC & $\begin{array}{l}\text { WASHINGTON NAVY } \\
\text { YARD }\end{array}$ & $\begin{array}{l}\text { DISTRICT OF } \\
\text { COLUMBIA }\end{array}$ & 1,710 & 57.05 \\
\hline ARMY & FORT WAINWRIGHT & FORT WAINWRIGHT & ALASKA & 1,724 & 57.52 \\
\hline
\end{tabular}


Table A.1 (continued)

\begin{tabular}{|c|c|c|c|c|c|}
\hline Component & Installation Name & City & State / Country & $\begin{array}{c}\text { Total Site } \\
\text { Delivered } \\
\text { Energy } \\
\text { (BBTU) Goal } \\
\text { Subject } \\
\end{array}$ & $\begin{array}{c}\text { Annual } \\
\text { Average } \\
\text { Site Energy } \\
\text { (MWe) } \\
\end{array}$ \\
\hline AIR FORCE & PETERSON AIR FORCE BASE & $\begin{array}{l}\text { COLORADO } \\
\text { SPRINGS }\end{array}$ & COLORADO & 1,811 & 60.42 \\
\hline NAVY & NAVSTA NORFOLK VA & NORFOLK & VIRGINIA & 1,827 & 60.96 \\
\hline AIR FORCE & ROBINS AIR FORCE BASE (AFMC) & ROBINS AF BASE & GEORGIA & 1,837 & 61.29 \\
\hline ARMY & FORT HOOD & KILLEEN & TEXAS & 1,875 & 62.56 \\
\hline AIR FORCE & EIELSON AIR FORCE BASE & MOOSE CREEK & ALASKA & 2,004 & 66.86 \\
\hline DIA & JOINT BASE ANACOSTIA-BOLLING & WASHINGTON & $\begin{array}{l}\text { DISTRICT OF } \\
\text { COLUMBIA }\end{array}$ & 2,036 & 67.93 \\
\hline ARMY & JOINT BASE LEWIS MCCHORD & TACOMA & WASHINGTON & 2,078 & 69.33 \\
\hline NAVY & $\begin{array}{l}\text { NAVBASE KITSAP BREMERTON } \\
\text { WA }\end{array}$ & BREMERTON & WASHINGTON & 2,120 & 70.73 \\
\hline AIR FORCE & HILL AIR FORCE BASE & OGDEN & UTAH & 2,256 & 75.27 \\
\hline NSA & FORT GEORGE G MEADE & FORT MEADE & MARYLAND & 2,534 & 84.54 \\
\hline ARMY & HOLSTON AAP (GOCO) & KINGSPORT & TENNESSEE & 2,568 & 85.68 \\
\hline AIR FORCE & TINKER AIR FORCE BASE & OKLAHOMA CITY & OKLAHOMA & 2,703 & 90.18 \\
\hline NAVY & CFA YOKOSUKA JA & FPO & JAPAN & 2,729 & 91.05 \\
\hline ARMY & ABERDEEN PG & ABERDEEN & MARYLAND & 2,734 & 91.22 \\
\hline AIR FORCE & $\begin{array}{l}\text { WRIGHT PATTERSON AIR FORCE } \\
\text { BASE }\end{array}$ & $\begin{array}{l}\text { WRIGHT- } \\
\text { PATTERSON AFB }\end{array}$ & $\mathrm{OHIO}$ & 2,828 & 94.35 \\
\hline ARMY & RADFORD AAP (GOCO) & RADFORD & VIRGINIA & 2,949 & 98.39 \\
\hline USMC & CG MCB CAMP LEJEUNE NC & CAMP LEJEUNE & NORTH CAROLINA & 3,161 & 105.46 \\
\hline ARMY & FORT BRAGG & FORT BRAGG & NORTH CAROLINA & 3,504 & 116.91 \\
\hline AIR FORCE & JOINT BASE SAN ANTONIO (JBSA) & SAN ANTONIO & TEXAS & 3,726 & 124.31 \\
\hline
\end{tabular}


Appendix B

Alaska Energy Generation Statistics 


\section{Appendix B}

\section{Alaska Energy Generation Statistics}

Table B.1. Alaska total annual energy generation (MWh) [14].

\begin{tabular}{|c|c|c|c|c|c|c|c|c|c|c|c|}
\hline Year & 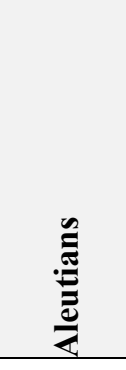 & 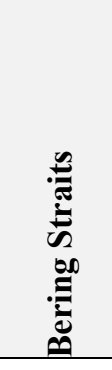 & 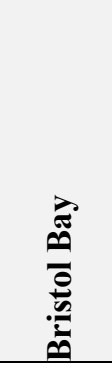 & 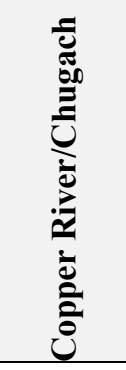 & 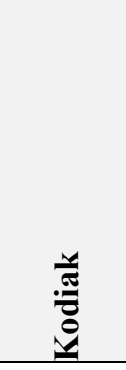 & 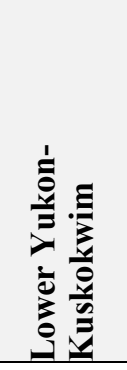 & 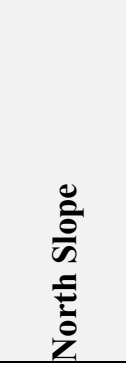 & 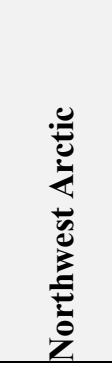 & 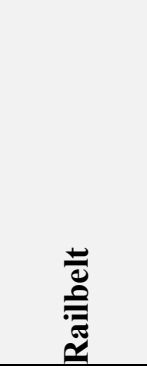 & 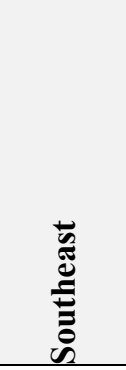 & 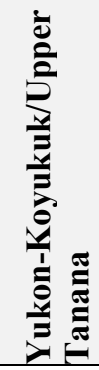 \\
\hline 2008 & 50962 & 60801 & 54037 & 107259 & 144021 & 93591 & 60018 & 36180 & 5171486 & 723465 & 36130 \\
\hline 2009 & 51387 & 54659 & 50115 & 114405 & 127748 & 94184 & 80467 & 36546 & 5057740 & 749035 & 36183 \\
\hline 2010 & 48649 & 20522 & 54704 & 131406 & 147925 & 102246 & 76570 & 34779 & 5029282 & 791596 & 36526 \\
\hline 2011 & 107218 & 57691 & 53622 & 134245 & 150564 & 97469 & 80336 & 35823 & 5076251 & 792046 & 30187 \\
\hline 2012 & 110899 & 55971 & 55918 & 120639 & 155892 & 101939 & 153397 & 37664 & 5010178 & 843141 & 36370 \\
\hline 2013 & 65266 & 54071 & 53046 & 121301 & 154367 & 98609 & 84382 & 36335 & 4623852 & 880133 & 35839 \\
\hline
\end{tabular}

Table B.2. Alaska average energy demand (MW). The annual total values in the table above have been divided by the number of hours in a year ( 8760 hours).

\begin{tabular}{|c|c|c|c|c|c|c|c|c|c|c|c|}
\hline Year & 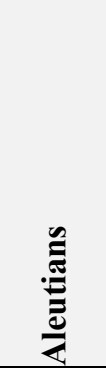 & 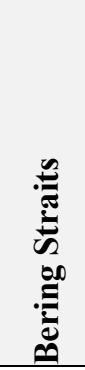 & $\frac{\overrightarrow{0}}{0}$ & 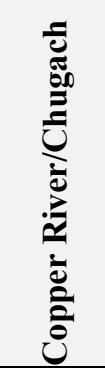 & 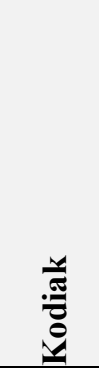 & 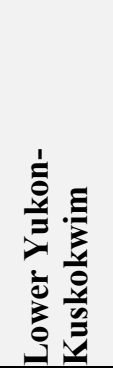 & 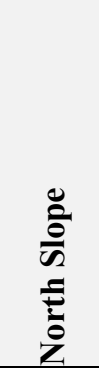 & 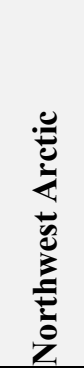 & 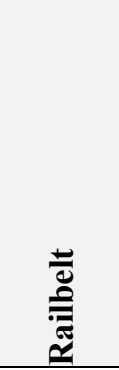 & 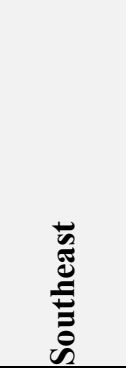 & 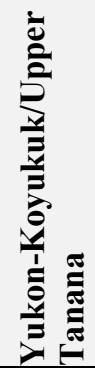 \\
\hline 2008 & 5.82 & 6.94 & 6.17 & 12.24 & 16.44 & 10.68 & 6.85 & 4.13 & 590.35 & 82.59 & 4.12 \\
\hline 2009 & 5.87 & 6.24 & 5.72 & 13.06 & 14.58 & 10.75 & 9.19 & 4.17 & 577.37 & 85.51 & 4.13 \\
\hline 2010 & 5.55 & 2.34 & 6.24 & 15.00 & 16.89 & 11.67 & 8.74 & 3.97 & 574.12 & 90.36 & 4.17 \\
\hline 2011 & 12.24 & 6.59 & 6.12 & 15.32 & 17.19 & 11.13 & 9.17 & 4.09 & 579.48 & 90.42 & 3.45 \\
\hline 2012 & 12.66 & 6.39 & 6.38 & 13.77 & 17.80 & 11.64 & 17.51 & 4.30 & 571.94 & 96.25 & 4.15 \\
\hline 2013 & 7.45 & 6.17 & 6.06 & 13.85 & 17.62 & 11.26 & 9.63 & 4.15 & 527.84 & 100.47 & 4.09 \\
\hline
\end{tabular}

